\title{
DE VOORMALIGE ROMAANS-GOTISCHE KERK VAN DE SINT-PIETERSABDIJ TE GENT
}

\author{
door \\ Arch. Dr. ROGER VAN DRIESSCHE \\ In aandenken aan onze geliefde zoon Hendrik \\ (Gent 26 januari 1951 - Vézelay 4 september 1973).

\section{WOORD VOORAF}

Reeds zeer vroeg beschikt men voor de Sint-Pietersabdij over een buitengewoon rijk archief, dat op heden bewaard wordt in het rijksarchief te Gent. Cartularia, akten en kontrakten, briefwisseling, kronieken, memorieboeken en rekeningen allerhande brengen ons informatie, zowel over de gebouwen als over hun inboedel.

Met deze studie willen wij dan een poging wagen om een beeld te schetsen vooral van de romaans-gotische kerk die - in de loop van de eeuwen - aan de huidige O.-L.-Vrouw-Sint-Pieterskerk is voorafgegaan.

Zolang er evenwel in de ondergrond van de bestaande kerk en haar onmiddellijke omgeving geen ernstige opgravingen kunnen ondernomen worden, menen wij het veiliger ons te onthouden van al te gewaagde suggesties nopens de structuur van dit verdwenen bedehuis.

Derhalve dachten wij het aangewezen, prioriteit te moeten verlenen aan het voorhanden zijnde bronnenmateriaal boven moeilijk te bewijzen en vaak omstreden hypothesen.

In dit verband zijn wij zeer verplicht aan Prof. Jos. Duverger, die jaren terug - het archiefonderzoek van de eens zo machtige abdij heeft aangevat en nooit ophield ons in die richting te stimuleren. Dank ook aan het Gentse Stadsbestuur dat in 1950 het initiatief heeft genomen om in de gewezen abdij opsporings- en restauratiewerken te laten uitvoeren. Van de speciale Commissie, belast met de supervisie van deze werken, mochten wij - samen met Dr. Henri Nowé en Prof. Dr. Firmin de Smidt - deel uitmaken.

\section{BOUWGESCHIEDENIS}

Voor het vestigen van een gebedsoord was de Blandinusberg, gelegen aan de over van de Schelde, een uitmuntende keuze ${ }^{1}$. Zij was niet alleen gunstig gelegen voor het aanvoeren van bouwmaterialen, zij vormde tevens

(1) G. de Clercq, De kerkelijke instellingen te Gent in verband met de oudste stedelijke geschiedenis, in: Nederlandse historiebladen, 2.2, Antwerpen, 1939, p. 118. 
een schakel voor de verspreiding van de nieuwe geestelijke stromingen naar de meest verwijderde gewesten van dit gedeelte van ons continent: Opgericht gedurende het leven van de Heilige Amandus circa het midden van de $7 e$ eeuw, kreeg de jonge stichting reeds in het eerste kwart van de 8ste eeuw een zware klap te verduren. Inderdaad, Karel Martel hertog van Austrasië verjoeg in 716 abt Celestinus die de partij van zijn rivaal hofmeier Ramanfred had gekozen. Hij verdeelde de abdijgoederen onder zijn vazallen, met als gevolg dat het klooster in verval geraakte. Dit zou duren tot onder Lodewijk de Vrome die Einhard - biograaf van Karel de Grote - in 814 of 815 tot lekenabt benoemde. Deze Erasmus van de 9de eeuw zou de fundamenten gelegd hebben van een nieuwe kerk ${ }^{2}$.

Nauwelijks was de grote keizer ter ziele gegaan of de Vikings vielen Vlaanderen binnen. In 846 kwamen zij de Schelde opgevaren en brak er te Gent paniek los. Pieter-en Bavelingen namen hals over kop de vlucht naar Frankrijk waar zij zich in Laon vestigden ${ }^{3}$.

De eerste betrouwbare gegevens over een bedehuis beginnen evenwel pas met de luisterrijke overbrengst in 870 van de relieken van de $\mathrm{H}$. Amelberga uit Temse naar het koor van de abdijkerk ${ }^{4}$.

$\mathrm{Na}$ de dood van graaf Boudewijn I (879) werd zijn hart bijgezet in de O.L. Vrouwkapel. Nadat de Engelse koning Alfred de Grote in 879 de Vikings overwonnen had, overstroomden zij het noorden van Francia en werd de Sint-Pietersabdij verwoest. Opnieuw zochten de kloosterlingen hun heil in de vlucht en vestigden zich terug in Frankrijk.

Hoewel de Noormannen reeds in 883 de scheldestreek ontruimd hadden werden zij toch maar definitief in 891 door de Duitse keizer Arnulf van Karinthie te Leuven verslagen. $\mathrm{Zij}$ verlieten voor goed ons land en zochten via Bonen een goed heenkomen naar Engeland.

De Pieterlingen keerden maar jaren later - in 937 - naar hun zwaar gehavend klooster terug. Dit werd door bemiddeling van Graaf Arnulf I (918-965) in 941 opnieuw ingericht, nadat hij hun - niet zonder moeite - gedwongen had de regel van de $\mathrm{H}$. Benediktus te omhelzen. Hieraan zal de toenmalige abt Gerard van Brogne wel niet vreemd geweest zijn. Wegens de grote aangroei van de communauteit en de stijgende toeloop van gelovigen werd in 960 de bestaande kerk afgebroken en besloot men een nieuwe te bouwen. Dit kan in verband gestaan hebben met de luisterrijke overbrenging, in 945, van de relieken van de Heiligen Wandregiselis, Ansbert en Wulfram ${ }^{5}$. De werken vorderden zo snel dat het koor reeds in

(2) A. Verhulst, Over de stichting en oudste geschiedenis van de Sint-Pietersen de Sint-Baafsabdijen te Gent, Handelingen van de Maatschappij voor Geschiedenis en Oudheidkunde te Gent, 1953, D.VII, pp. 1-153; F.L. Ganshof, Vlaanderen onder de eerste graven, Antwerpen, 1944, pp. 13-19; Ph. Schmitz, Blandin, in: Beaudrillart, Dictionnaire d'Histoire et de Geographie Ecclesiastique, Parijs, D.IX, pp. 118-123; E. Moreau, Histoire de l'Eglise en Belgique, Brussel, 1940, D.II, pp. 159, 175-176.

(3) L. van der Essen, in: Geschiedenis van Vlaanderen, z.d. D.I, pp. 157-158.

(4) $\mathrm{Ph}$. Grierson, The Translation of the relics of St-Amelberga to St-Peters of Ghent, in: Rev. Ben. Maredsous, 1937, pp. 292-315.

(5) V. Fris, Histoire de Gand, Gent 1930, pp. 7-9; L. van der Essen, o.c., D. I, P. 160 ; F.L. Ganshof, o.c., pp. 14-16; F. van de Putte, Annales Abbatiae 
975 door Abelbertus, bisschop van Reims kon ingezegend worden en de westtoren in 979 door Hetbert, aartsbisschop van Trier. Deze westbouw kan - zoals blijkt uit een rekening in 1401-1408 nog bestaan hebben ${ }^{6}$.

$\mathrm{Na}$ de brand van 985 liet abt Wichard geheel de kerk vergroten. Koning Edward die in 1016 in de abdij in ballingschap vertoefde zou eveneens - na zijn reïnstallatie op de Engelse troon - de uitvoering van deze werken daadwerkelijk steunen. Tien jaar later liet abt Adalwinus de kerk opnieuw uitbreiden?

Aanvankelijk fungeerden de kloosterkerken tevens als openbare bidplaats. Zo begrijpt men dat er in de meest betrouwbare bronnen steeds opnieuw gesproken wordt over een massa gelovigen die de Goddelijke diensten bijwoonden.

Volgens de "Vita Bertulfi Renticensis" was de toeloop op Drievuldigheidszondag van het jaar 1073 buitengewoon groot. Dit zou misschien in verband kunnen worden gebracht én met het feit dat het Sint-Pietersaltaar toen naar het midden van de kerk werd verplaatst vóór de viering, én met de verruimingswerken die aan het koor plaats grepen ${ }^{8}$.

Het is opvallend hoe er, vanaf 1074 gewag wordt gemaakt van vrije lieden die zich onder de schutse stellen, ad altare beatae Mariae, semper virginis; in cripta ecclesiae sancti Petri Gandensis". Tot en met 1270 werden die akten regelmatig vernieuwd ${ }^{\circ}$.

Gosewijn, bisschop van Doornik, mocht in 1216 de O.L.-Vrouwkapel inzegenen die gelegen was achter het koor. Klaarblijkelijk werd dan het eindpunt bereikt van de in 1073 ingezette bouwwerken ${ }^{10}$.

Volledigheidshalve dient hier nog aangestipt te worden dat Anselmus,

Sancti Petri Blandinienses, 1842, p. 9; Ph. Schimtz, o.c.; 1.c. de Moreau, o.c., 1.c.

(6) F. van de Putte, o.c., p. 9; P. Grierson, Les annales de Saint-Pierre à Gand et de Saint-Amand - Annales Blandinienses - Annales Elmarenses - Annales Vormoselenses - Annales Elnonenses, Brussel, 1937, p. 21; Ch. Diericx, Memoires sur la ville de Gand, Gent, 1897, D.II, p. 335; Jacobus Meyerus, Commentarii Sivi Annales rerum Flandricarum Libri septendicim, Antwerpen, 1561, fo 20vo; doc. $10^{5,21}$.

(7) M. Deruelle, De St-Pietersabdij te Gent, Gent 1933, p. 27; M. van Vaernewijck, Historis van Belgis, edit. J. van der Haeghen, Gent 1829, D.II, p. 184; A. Sanderus, Gandavum sive Gandavansium rerum liberi sex, Brussel, 1627, p. 304; Anno 985 - inchoatum est aedificium blandiniense in majores structuras sub Widone praefato die kalendarum aprilis (Rijksarchief Gent, Fonds St-Pieters, I reeks, nr 81 fo $58 \mathrm{vo}$ - aantekeningen uit de $16^{\mathrm{e}}$ eeuw door Sigerus Piscatoris); anno 995 - In lapide quadrato scicei (?) albo erat: Hic jacet abbas Adaluinus sacerdos, qui obiit $17 \mathrm{cal}$. Juli anno Domini 995: Rexit hanc Blandinii ecclesiam annis VIII et mensibus VII (Univ. bibl. Gent, hs. G. 11767 fo 3vo).

(8) G. de Clercq, o.c., p. 119-120; M. Deruelle, o.c., p. 28; O. Holder-Egger, in: Monumenta Germaniae Historica Scriptores, D.XV, 2, p. 240.

(9) A. van Lokeren; Chartes et documents de l'Abbaye de Saint-Pierre au Mont Blandin à Gand, Gent, 1868-1871, D.I., pp. $104 \mathrm{nr}$ 155, $106 \mathrm{nr}$ 158, 112 $\mathrm{nr} 174,119 \mathrm{nr} 188,125 \mathrm{nr} 200,135 \mathrm{nr} 221,137 \mathrm{nr} 227,142 \mathrm{nr} 237,148 \mathrm{nr} 251$,

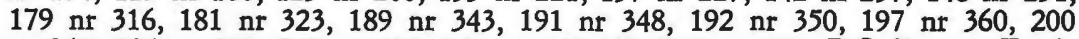
nr 367, 206 nr 378, 242 nr 454, 245 nr 461-462, 249 nr 477; P.C. Boeren, Etude sur les Tributaires d'Eglise dans le Comté de Flandre du IX ${ }^{\mathbf{e}}$ au XIV ${ }^{\circ}$ siècle, Amsterdam, 1936, p. $140 \mathrm{nr} 47$.

(10) F. van de Putte, o.c., p. 17. 
bisschop van Doornik in 1148, de krypte van het klooster zou ingewijd hebben ${ }^{11}$.

Gedurende de eerste helft van de 13 de eeuw verflauwt in onze gewesten de gewoonte om zich onder de hoede te stellen van een altaar. Dit kan één van de reden zijn waarom er in de documenten van de 14 e eeuw niet meer over de krypte gesproken wordt ${ }^{12}$.

De ankoop in 1408, bij meester Jan van Dendermonde o.m. van "eenen kerteelsteen ghebuerbuert onder Sinte-Andriescapelle in de voute" zou er hooguit op kunnen wijzen dat een gedeelte van de crypte onder de noordtransept gelegen was ${ }^{13}$.

Ook is het mogelijk dat bij het vergroten van het koor de crypte niet werd uitgebreid.

In 1566 onteerden de iconoclasten in de Sint-Pieterskerk o.m. de vorstelijke begraafplaatsen, liggende aan de ingang van de door negen stenen zuilen ondersteunde O.L. Vrouwkapel ${ }^{14}$. Hieruit kan worden opgemaakt dat deze tomben niet in de crypte dienden gezocht te worden. Trouwens, het verslag op 2 oktober 1567 uitgebracht door twee leden van de Raad van Vlaanderen nl. François Courteville en Jean van der Burght handelt uitvoerig over de door de iconoclasten aangebrachte schade, maar rept met geen woord over het bestaan van een crypte in de St-Pieterskerk. Dit kan tot nadenken stemmen. Wat meer is, uit dit belangrijk rapport is geweten dat er zich boven de O.L. Vrouwkapel een altaar bevond toegewijd aan de $\mathrm{H}$. Drievuldigheid ${ }^{15}$.

Uit documenten van 1406 en 1412 is gekend dat de reliekschrijnen toen reeds geplaatst waren op een soort steiger boven het hoofdaltaar en niet in de crypte; dat de juwelen bewaard werden in de schatkamer op de verdieping van de "prespeterie" ten westen van de St.-Laurentiuskapel, en de ornaten in de "trianghele" die o.i. te situeren is boven de O.L. Vrouwkapel ${ }^{16}$.

In 1517 werd de relikwiestijger vervangen door de zgn. „ijzeren zolder", ontworpen door G. Horenbault ${ }^{17}$.

Ook de Florentijnse edelman Guicciardini (1521 - Antwerpen 1589), die het grootste gedeelte van zijn leven in ons land doorbracht, spreekt in zijn werk met veel lof over dit kunstwerk, maar zwijgt in alle talen over de crypte ${ }^{18}$.

Bij het uitvoeren van restauraties in 1613 werd in de zuidmuur van de St.-Benediktuskapel het graf blootgelegd van de in 995 overleden abt Adalwinus. Een gedenksteen aangebracht in de binnenwand van de oost-

(11) A. Sanderus, Gandavum, p. 312.

(12) P.C. Boeren, o.c., pp. 90-92.

(13) Doc. $20^{6}$.

(14) M. van Vaernewijck, Historie van Belgis, Gent, 1574, IV, cap. XLVIII, fo $\mathrm{CXIXV}^{\circ}$,

(15) Doc. 47.

(16) Doc., 15, $24^{4}$.

(17) M. Deruelle, o.c., pp. 118-121.

(18) L. Guicciardini, Descrizione de tuti i Paesi Bassi, Antwerpen, 1567, uitgave Amsterdam 1612, p. 293. 
pandgang herinnert ons nog steeds aan deze opzienbarende ontdekking ${ }^{19}$.

Dergelijke vondsten schijnen later nooit meer voor te komen, ook niet gedurende de bouwcampagne van de barokkerk. Hieruit zou kunnen besloten worden dat de ondergrond van de voormalige kerk onberoerd werd gelaten.

Wegens de scherpe helling van de bodem Scheldewaarts moet de crypte zich zeer duidelijk boven het maaiveld afgetekend hebben. De hypothese dat men - in het vooruitzicht van de tweede beeldenstorm (1578) - de ingang van de crypte zou toegemuurd en gecamoufleerd hebben, schijnt ons derhalve absurd als zijnde met de werkelijkheid in strijd ${ }^{20}$.

Zou het dan gewaagd zijn te stellen dat tijdens de vele werken die in de loop van de 14 de eeuw aan de kerk werden uitgevoerd de crypte overbodig was geworden en misschien gedeeltelijk met slopingsmateriaal werd volgestort, nadat men het opstaand gedeelte op gelijk peil van het schip had gebracht?

Volgens de Busscher kwam men eertijds van uit de pand door een galerij onder de linkerbeuk van de kerk waar nog resten te zien waren van grafsteden zonder enige inscriptie ${ }^{21}$. Bij de situering dient o.i. gelet op de oriëntatie en werd hier de keldering bedoeld gelegen onder de zuidkooromgang van de barokkerk.

Het peil van die kelder werd later om een niet goed te praten reden méér dan een meter afgelaagd. Zo verdwenen klaarblijkelijk de laatste sporen van de zich dáár bevindende grafkelders.

Wat verder de romaanse kerk aangaat weet men uit een oorkonde van 1092, dat Margareta van Kortrijk de werken deed hervatten aan de bouwvallige St.-Niklaaskapel ${ }^{22}$.

Vanaf 1156 tot en met 1163 is er in de documenten sprake over een Maria-altaar in het atrium.

Hieruit concluderen dat de abdijkerk werd voorafgegaan door een atrium zoals dat in de strikt bouwkundige zin zou mogen opgevat worden lijkt ons voorbarig, daar uit andere bescheiden eerder blijkt dat men te doen heeft met de O.L. Vrouwkerk liggend op het domein van de abdij ${ }^{23}$.

Enorme schulden, vermoedelijk veroorzaakt door de bouwwerken van de 12 de en het begin van de 13 de eeuw, brachten de abdij aan de rand

(19) M. Deruelle, o.c., p. 170.

(20) M. Deruelle, o.c., pp. 52-53.

(21) E. De Busscher, Notes concernant l'abbaye de St-Pierre à Gand, in: Annales Soc. Royale des Beaux Arts et litterature, 1846-1847, DII, p. 39.

(22) In sacello Sti Nicolai eregione venerabilis sacramenti in pariete est:

Domina Margareta, Castellana Curtracensis reincipit hoc opus in honorem

D. Mariae, Sti Martini, Sti Nicolai et omnium etc. anno 1092

In codem in muro est quod sequitur:

Tempus edax rerum maculosa vetusta

Hoc pietatis opus quod tu Margareta decorat

Oblivione celut impellente morantur......

(Univ. bibliot. Gent, hs. G. 11767, fo 103; Kon. bibliot. Brussel, Epitaphes des Eglises de Gand, 16902, fo 23).

(23) A. van Lokeren, o.c., D.I, pp. 149, nr 253; 164, nr 287; M. Deruelle, o.c., p. 130 . 
van het bankroet. Bij staking van betaling legden de schuldeisers klacht neer te Rome. Op last van Paus Martinus IV stelde Philip Mouskes, bisschop van Doornik, een onderzoek in naar de gang van zaken. Het temporeel beleid werd op 5 april 1282 in handen gelegd van een comité bestaande uit vier leken. Deze wijze maatregel had voor gevolg dat de financiële moeilijkheden spoedig van de baan waren ${ }^{24}$.

In de tweede helft van de 14 de eeuw werd St.-Pieters geteisterd door felle branden $(1353,1368,1371,1376)$. Die van 1378 was voor de abdij gewoonweg catastrofaal. Toen werden niet minder dan circa vijfhonderd huizen in as gelegd, incluis de abdijkerk, de toren, de kloostergangen, de dormter, de refter en de infirmerie. Om de uitgaven te dekken die met de restauraties gepaard gingen, besloot abt Jan van Pitthem de jaarlijke inkomsten van het kasteel te Elmare, groot 600 pond parisis, aan te wenden ${ }^{25}$.

Bij de investituur in 1385 van Filips de Stoute, als graaf van Vlaanderen, waren de werken aan de benedenkerk nog volop aan de gang terwijl het koor, hetzij intakt gebleven, hetzij reeds in gebruik genomen was ${ }^{26}$.

Het feit dat Rome in 1393 Dom Antoon le Brun tot abt had benoemd was oorzaak van hoog oplaaiende twisten binnen de muren van de abdij en van de stad Gent. Onlusten vresend deed prelaat van Leeuwaerde, én de privilegieën én de relieken eerst overbrengen naar Oudenaarde en vandaar naar Douai ${ }^{27}$. Deze innerlijke twist verlamde de bouwactiviteit zodanig dat volgens de kontrakten en de generale rekeningen de werken tot in 1395 aansleepten.

Dit jaar betekende evenwel de kentering met de aanstelling van Laurens van der Leyen tot meester van de werken, met als opdracht het bouwen van de vieringstoren die zeker zo goed diende te zijn als deze die hij te Hulst had opgetrokken. Negenendertig jaar lang bleef van der Leyen de werken aan de kerk van de Pieterlingen in handen houden ${ }^{28}$.

Belangrijk is o.m. het feit dat in 1397-98 o.m., het gruis liggend op 't gewelf van "Bavstorre" gestort werd bij al het ander dat reeds van vroeger in de kerk lag en "Thuutlaes" voorhanden in het paradijs aan de St.-Andrieskapel (noord-transept) afgebroken werd.

Het slopingsmateriaal gedeeltelijk liggend op het O.L. Vrouwkerkhof werd weggevoerd naar het kerkhof palend aan de kerk, ten oosten van de kapittelzaal ${ }^{28}$.

De bekende Gentse zerkbouwer Jan Eebins, die voor het eerst in 1397 in de rekeningen van de abdij opduikt, kontrakteerde op 9 maart 1399 om onder de boog van het koor een opengewerkte gevel te bouwen voorzien

(24) A. van Lokeren, o.c., D.I., p. 391; M. Deruelle, o.c., p. 29.

(25) P.C. van der Meersch, Memorieboek der stad Gent, Gent, 1859, p. 74 en vlg., A. van Lokeren, o.c., D. II, nr 1290.

(26) G. Celis, Eenige aanteekingen over de blijde inkomsten der Graven van Vlaanderen in de St-Pietersabdij, in: Bulletijn Mij Geschied- en Oudheidkunde Gent, 1919, p. 16.

(27) A. van Lokeren, o.c., D.II, p. 117, nr 1400.

(28) doc. $2,3^{1-2}, 4^{2}, 6,8,10^{13-15}, 11,12^{10-15}, 28$.

(29) doc. $4^{7-8}$. 
van venster en beeldnissen. Dit alles volgens eigen ontwerp, diende uitgevoerd te worden in Lediaanse zandsteen ${ }^{30}$.

Het werk vlotte goed. Op 20 mei 1399 werd reeds met de beroemde Dendermondse beeldhouwer Jacob de Baerze een kontrakt gesloten tot het uitvoeren van het koorgestoelte, waarvan het ontwerp hem door abt G. van Leeuwaerde ter hand werd gesteld. Bij Hertog Filips de Schone heeft de Baerze in zeer hoge gunst gestaan. Algemeen kenmerk van zijn overgebleven werk is de ondergeschiktheid van de beelden aan de architectuur. Men mag dus veronderstellen dat het gestoelte in kwestie zal geharmonieerd hebben met het bouwwerk eerder opgericht door Eebins ${ }^{\mathbf{3 1}}$. Het gewelf van de viering kwam in ieder geval gereed in 1400. De overkluizing van het eertijds vermoedelijk vlak overzolderd koor, was in 1402-1403 af; want van der Leyen plaatste toen de daarop staande kranen ${ }^{32}$.

Uit het kontrakt van 8 september 1400 blijkt duidelijk dat de noordtransept voorzien was van een tribune die toegankelijk was vanuit de zich aldaar bevindende St.-Andrieskapel, bij middel van een wenteltrap aangebracht in de dikte van de muur. In die periode werden de vensters in de kruisbeuk aanmerkelijk vergroot. Men verlieze hierbij niet uit het oog dat de aanpalende noord-kloostergang toen geen verdieping bezat. Ook het klokketorentje met beiaard kwam in die tijd tot stand ${ }^{33}$.

Vanaf 1400 staat men voor een stijgende kurve van restauratie- en vergrotingswerken. De vestiaire van de abt, die zich onder het torentje van de kosterij ten oosten palend aan de noord-transept bevond, werd in 1402-1403 afgebroken, en het gruis dat reeds van oudsher op de „triniteit" lag weggeschaft ${ }^{34}$. Deze ,triniteit" - zoals wij reeds hoger aanstipten kan niets anders geweest zijn dan de bovenverdieping van de O.L. Vrouwkapel.

Belangrijk waren de verbouwingen uitgevoerd in 1406-1408. Toen werd m.i. de voorkerk naar het westen toe vergroot. De boog en de oude muur in de beuk werden gesloopt en de daarin liggende oude grafzerken verwijderd. Boven de St.-Benediktuskapel, ten zuiden van de kooromgang palend aan de dormter, werd een studeerkamer ingericht. Deze werken gingen gepaard met een grondig nazicht van koor en toren ${ }^{35}$.

Aan de binnenzijde was het koor afgesloten door een ringmuur, waarin zoals bekend uit de rekening van 1408 ,historiën" voorkwamen die met witte dekkleden werden omhangen. In de „presbyterie" zijnde de sacristie stonden (1404) tevens de in steen uitgevoerde verhalen over de geboorte en de dood van Jezus en Maria. Dergelijke bijbelse onderwerpen nl. „de aanbidding van de Driekoningen" treft men tot op heden nog aan in de

(30) R. van Driessche, Jan Eebins, in: Nationaal Biografisch Woordenboek, Paleis der Academiën, Brussel, 1964, D.1, p. 427-428; d. 5, 6, 127.

(31) D. Roggen, De twee retabels van de Baerze te Dyon in: Gentse Bijdragen tot de Kunstgeschiedenis, Gent, 1934, D.I, pp. 98, 104; d. 7, $10^{12}$.

(32) d. $8,10^{9-11}, 12^{13}$.

(33) d. $9,10^{14}, 17,19$.

(34) d. 126,14-15.

(35) d. 16-17. 
St.-Martenskerk te Halle, waar het koor omzet is met apostelbeelden die dateren uit het einde van de 14 de of het begin van de 15 de eeuw ${ }^{36}$.

$\mathrm{Bij}$ hoogdringendheid dienden in 1408 herstellingen gedaan te worden aan de St.-Amelbergakapel, de apsidiol op de transept ten zuid-oosten van het koorhoofd, de kapellen van de H.H. Katharina, Andries en Laurentius. Meteen belanden wij bij de beschuttingswerken die werden uitgevoerd alvorens over te gaan tot de afbraak van nagenoeg geheel de benedenkerk ${ }^{37}$.

Inderdaad, uit de akte op 10 juni 1408 verleden vóór de schepenen van de Gentse Keure, blijkt dat Gillis van Musschezele en Lieven van Lede zouden afbreken tot in de funderingen: de noordzijbeuk van de voorkerk, de ingang van de kerk alsmede de zich in deze gedeelten bevindende altaren. Het afkomend materiaal zou gestapeld worden op het oud kerkhof palend aan de kapittelzaal, terwijl het gruis - door een opening te maken in de muur van het kerkhof - moest gestort worden in de boomgaard; zij dus in de omgeving van het koorhoofd ${ }^{38}$. Om deze werken te financieren werden in $1411^{-}$enkele goederen verkocht ${ }^{39}$.

De in 1412 overleden abt van Leeuwaerde zal in zijn grafschrift o.m. voor dit werk worden geprezen. Vanaf dit ogenblik zal er in de rekeningen sprake zijn over ,,den nieuwen werke". Ook de herstellingen in die periode uitgevoerd an de St.-Amelbergakapel mogen als belangrijk .worden bestempeld, vooral dan om de versieringen die er door schilder Rogier van de Wostine werden uitgevoerd ${ }^{40}$.

Tot en met 1444 behelzen de generale rekeningen - nagenoeg ononderbroken - uitgaven in verband met het gehele kerkgebouw. Uit een betaling in 1436-1437 gedaan, blijkt dat er gevaar had gedreigd om van de kerken van St.-Baafs en St.-Pieters, versterkingen te maken ${ }^{41}$.

Circa 1444 werden zgz. ten zuiden van de toren nieuwe kapellen gebouwd. Dit is evenwel strijdig met de ordonnantie van de aanpalende kloostergang, tenzij men hier te doen had met het inrichten van kapellen in de zuid-transept, ofwel dat hier de Noordzijde werd bedoeld ${ }^{42}$.

Daarna treed een stagnatie in die zal duren tot in 1479 wanneer werd overgegaan tot het vernieuwen van het gewelf ten noorden van de „Triniteit", het bouwen (1480-81) 'van de muren en gewelven van de noordzijbeuk en dito transept. In de rekeningen worden deze werken betiteld als de "nieuwer-kerken" en... "den nyeuwen buec" 43 .

Aan kerk en abdij waren in 1493 zware restauraties nodig, zó dat op 26 januari 1497 besloten werd, de tienden waarover men in de parochie

(36) D. Roggen en M. de Vleeschouwer, De Apostelen en de Aanbidding der Driekoningen in de St-Martenskerk te Halle, in: G.B.K., D.I, Antwerpen, 1934, p. 166 ; d. 145,18 .

(37) d. $19-20$.

(38) Ch. L. Diericx, Memoires sur la ville de Gand, Gent, 1814-1815, D.II, p. $337, \mathrm{nr} 1$.

(39) A. van Lokeren, o.c., D.I, p. LXII.

(40) d. 22, 23, 24.

(41) d. 25-36.

(42) d. $37-40$.

(43) d. $41-46$. 


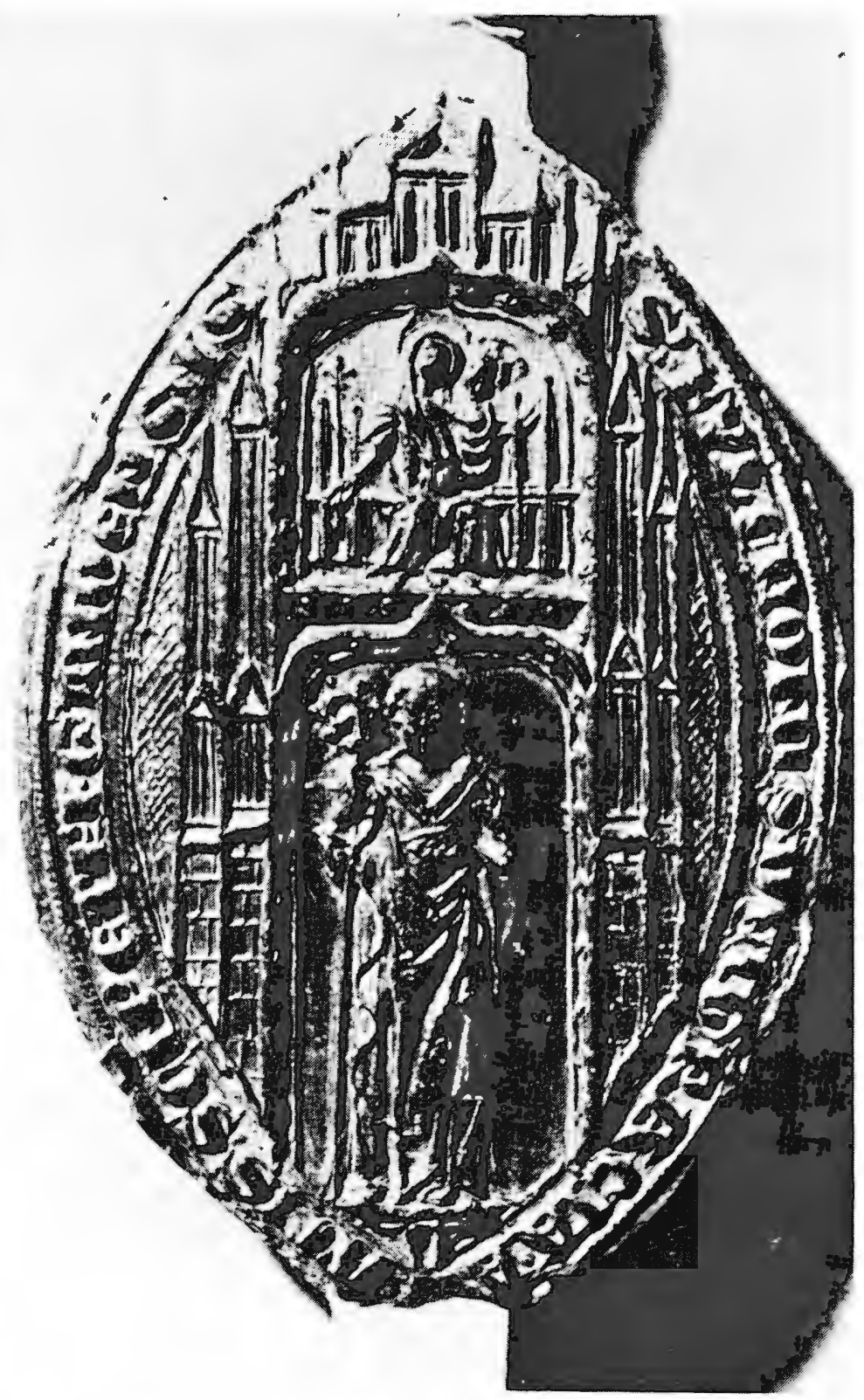

Afb. 1 - Zegel van abt Fulcro de Rijcke, 1321. Stadsarchief Gent, charter 68, in : Religieuze kunst in Oost-Vlaanderen, Gent, Bijloke Museum, 1951, katal. nr. 78. 


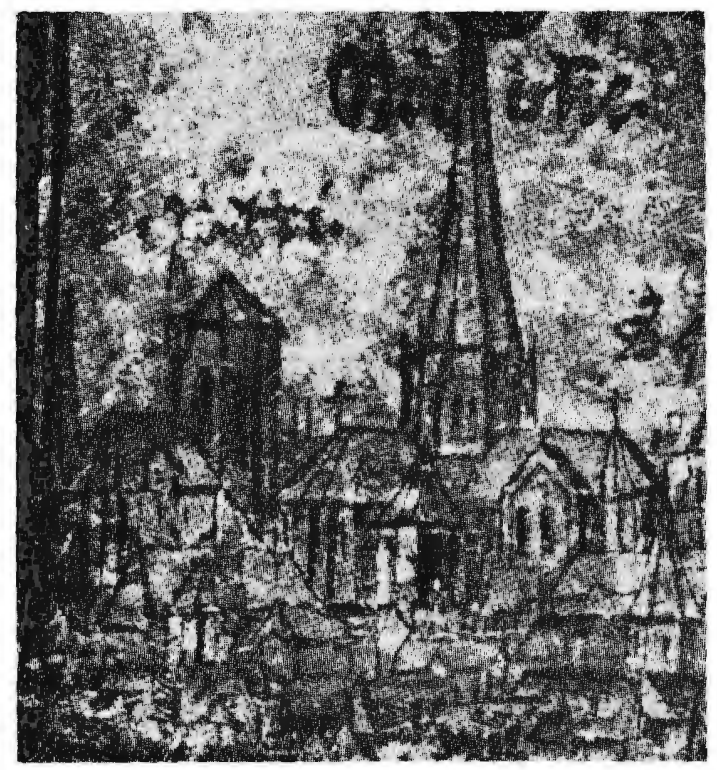

Afb. 2 - Detail uit het Panorama van de Stad Gent in 1524 door P. de Keysere.

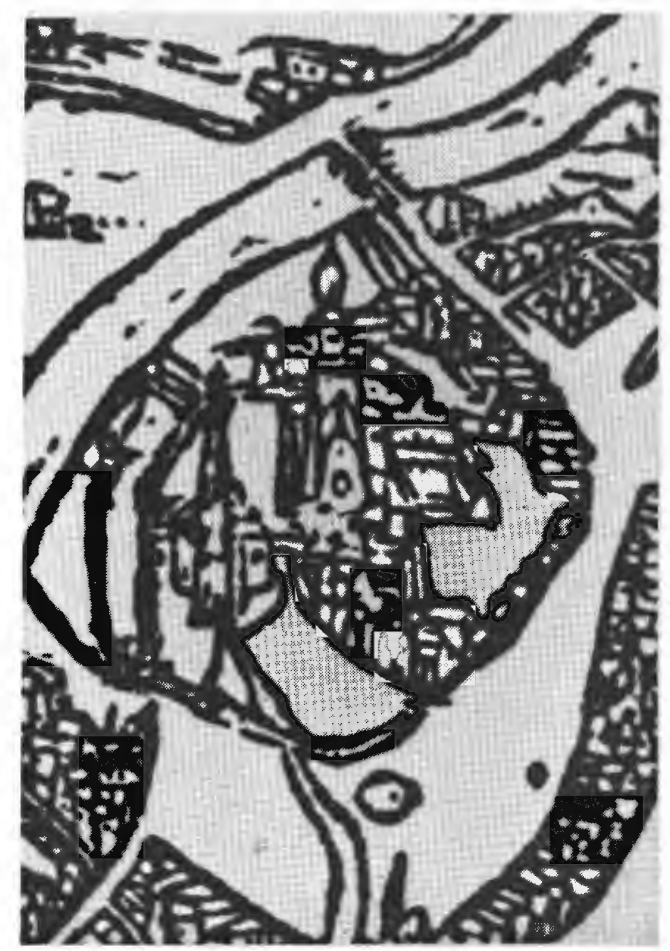

Afb. 3 - Detail uit de xylogravure van 1551 door Jan Oste. 


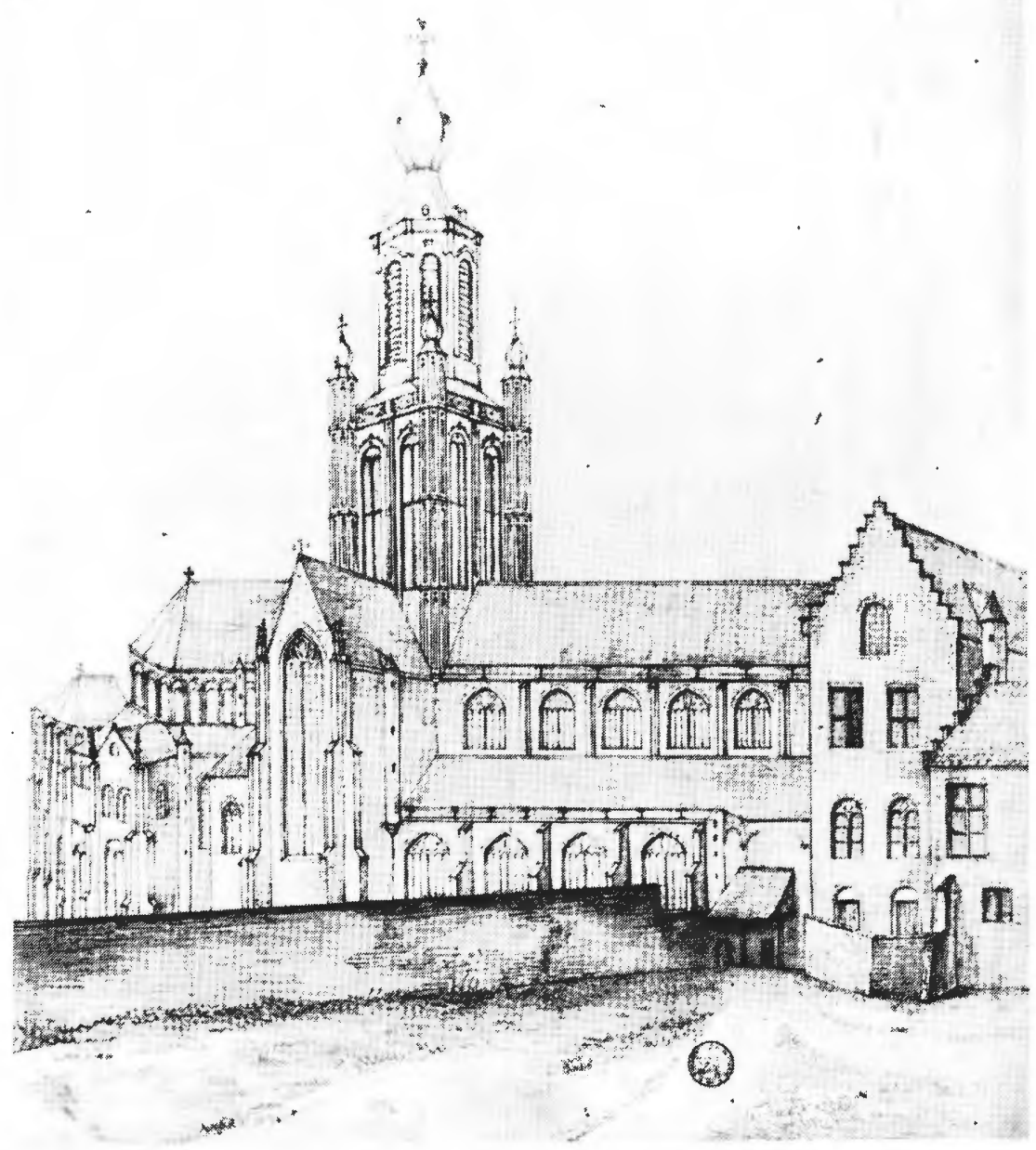

Afb. 4 - Abdijkerk. Noordzijde in 1560 door Arent van Wijnendaele, Stadsarchief Gent, atlas Goetghebuer. 


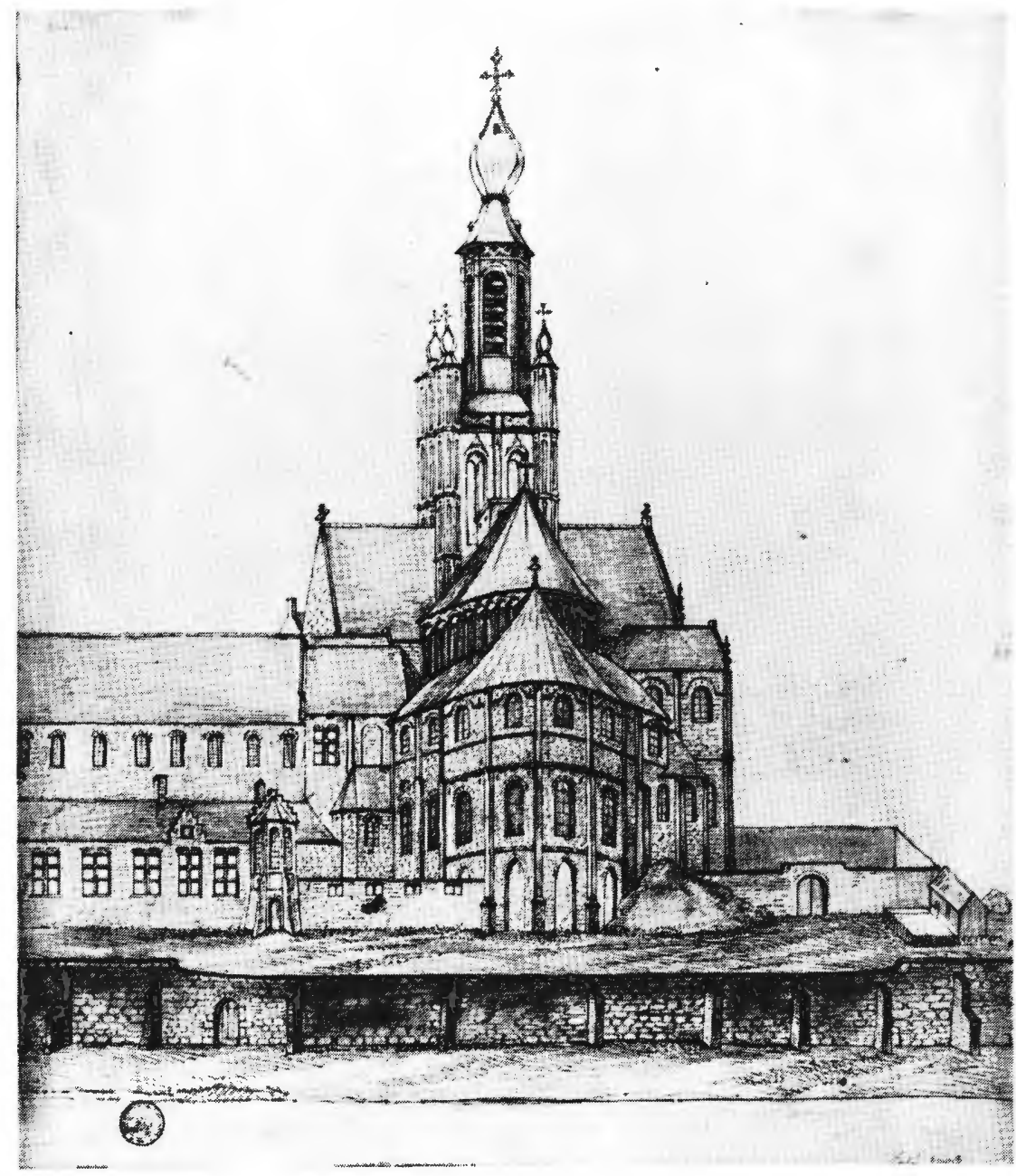

Afb. 5 - Abdijkerk. Oostzijde in 1560 door Arent van Wijnendaele, Stadsarchief Gent, atlas Goetghebuer 


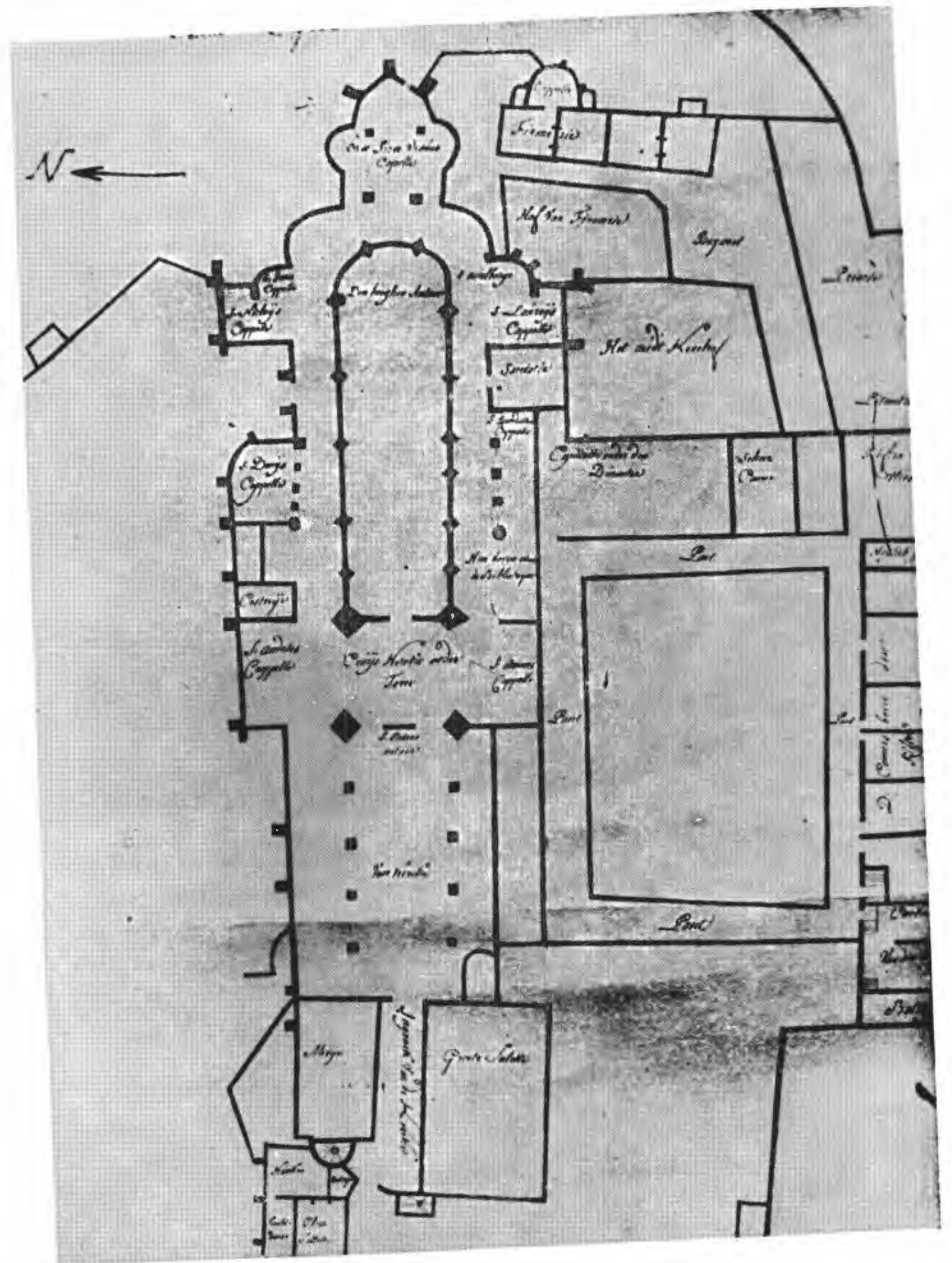

Afb. 6 - Detail van het „Rode Plan”, Rijksarchief, kaarten en plans, nr. 205. Voor Afb. 7 - zie blz. 16-17 van de tekst 


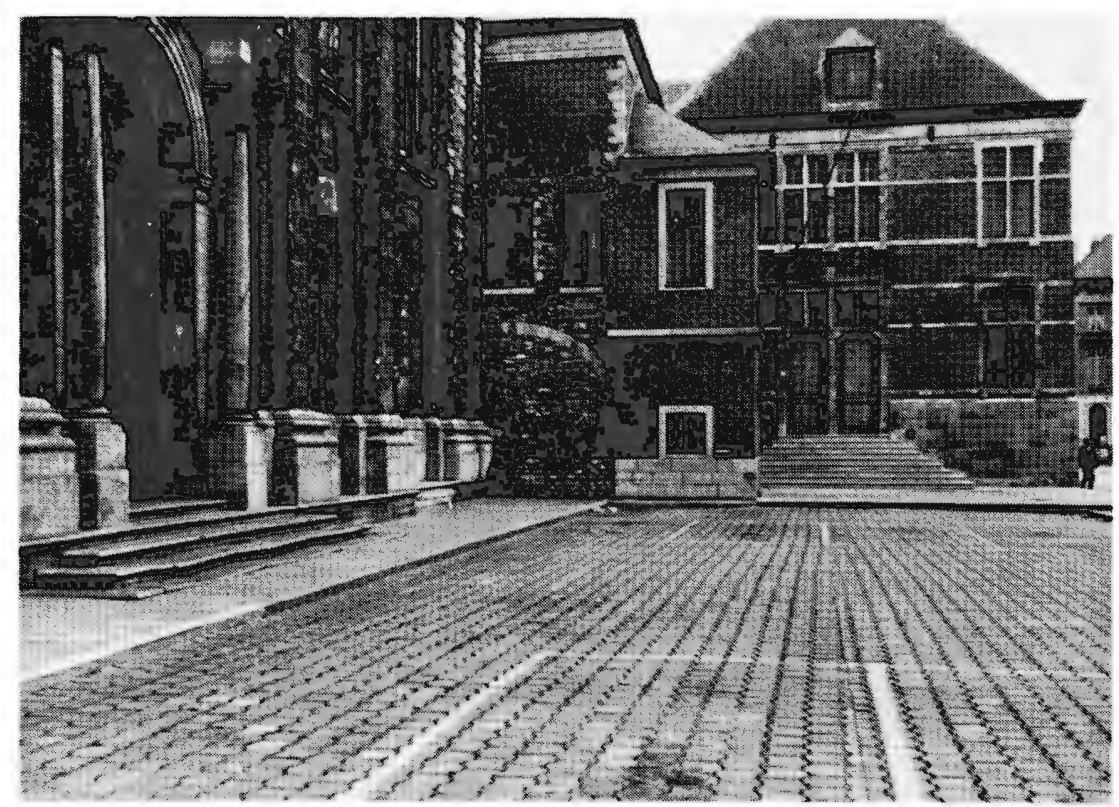

Afb. 8 - Toegemuurde ingang tot de lichthof van de kerk

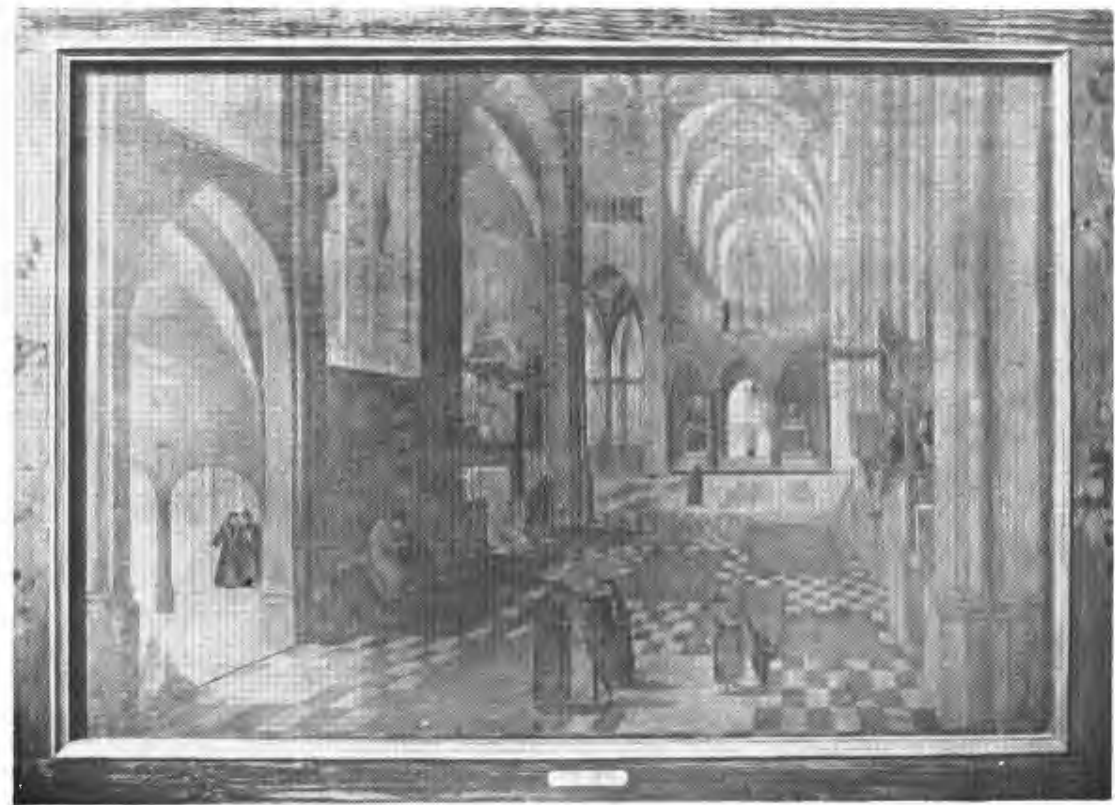

Afb. 9 - Vermoedelijk interieur van de romaans-gotische kerk (Bijloke Museum) 

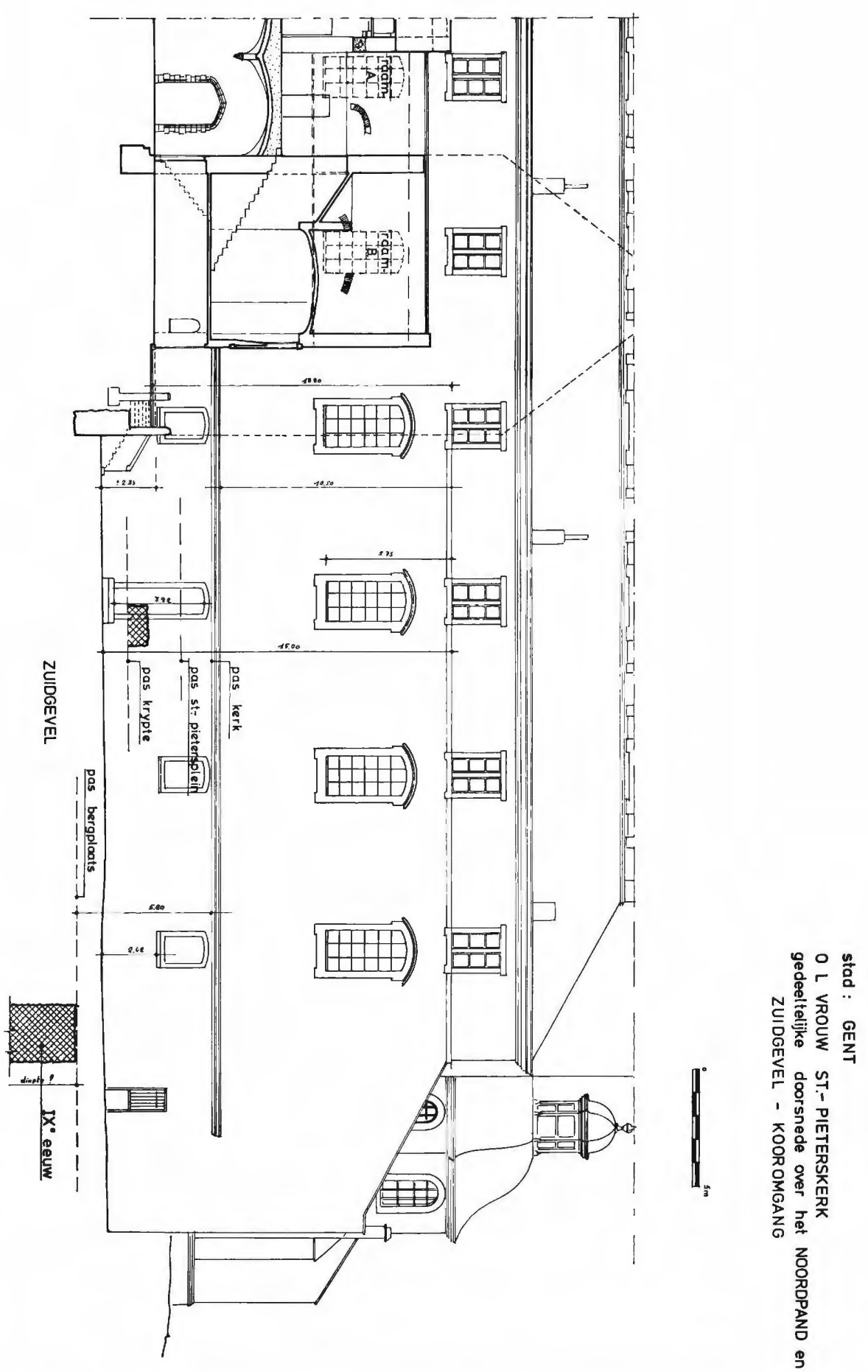

Afb. 10 - Gedeeltelijke lengtedoorsnede over de Noordpand en de zuidgevel van de barokkerk volgens opmetingen van Arch. Dr. R. van Driessche. 


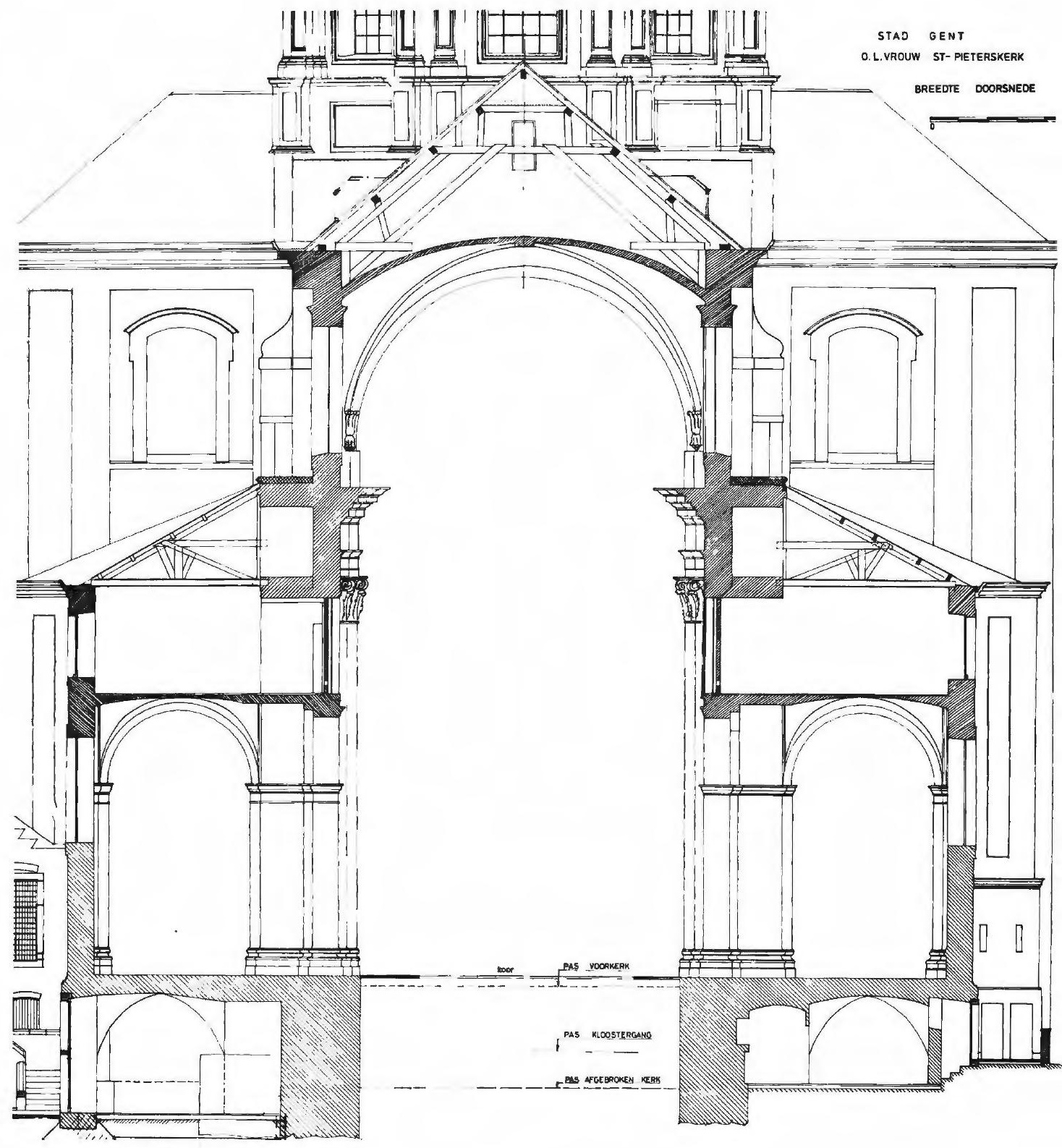

Afb. 11 - Breedtedoorsnede over het koor van de barokkerk volgens opmetingen van Arch. Dr. R. van Driessche 


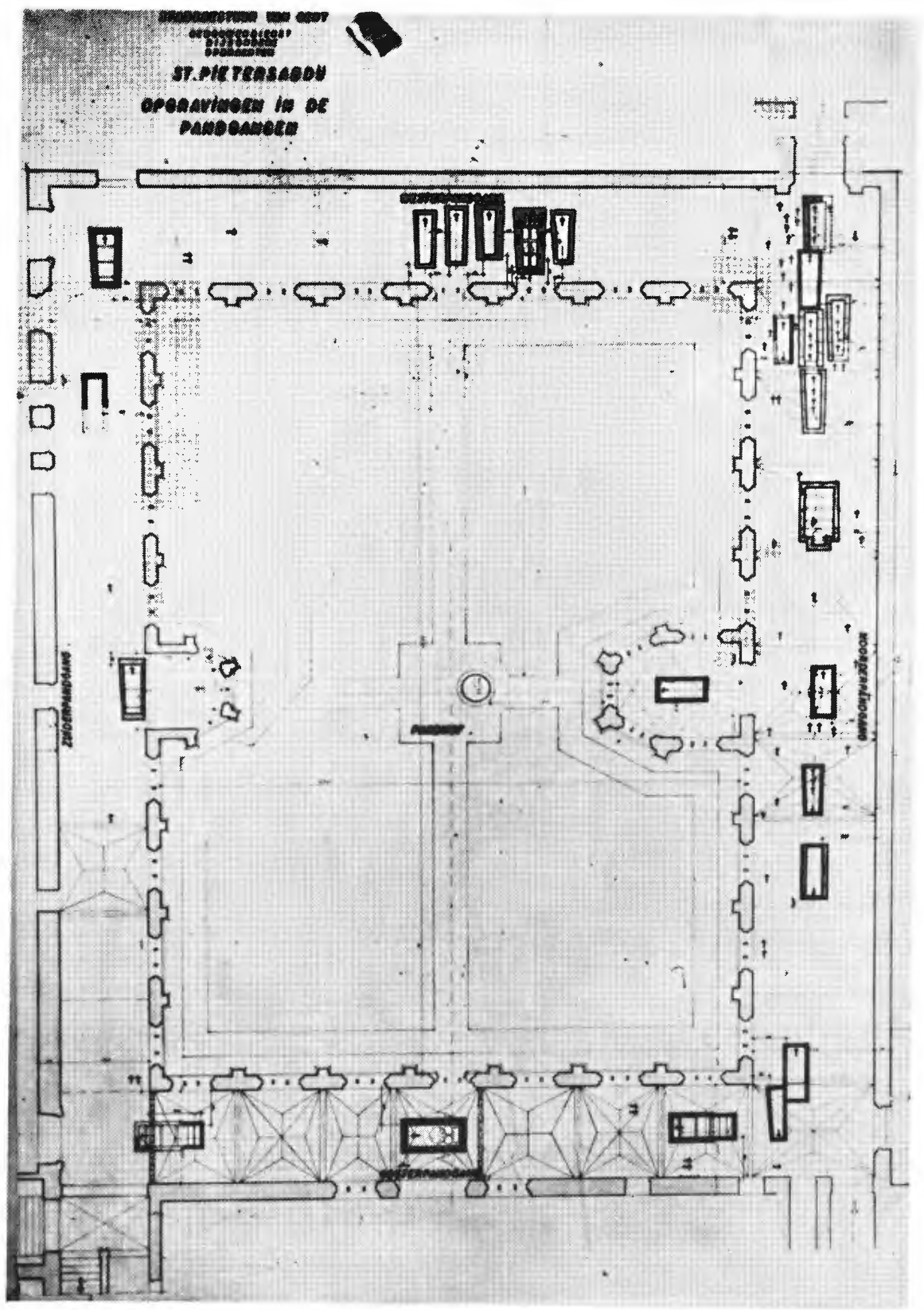

Afb. 12 - Kloostergang-grafkelders 


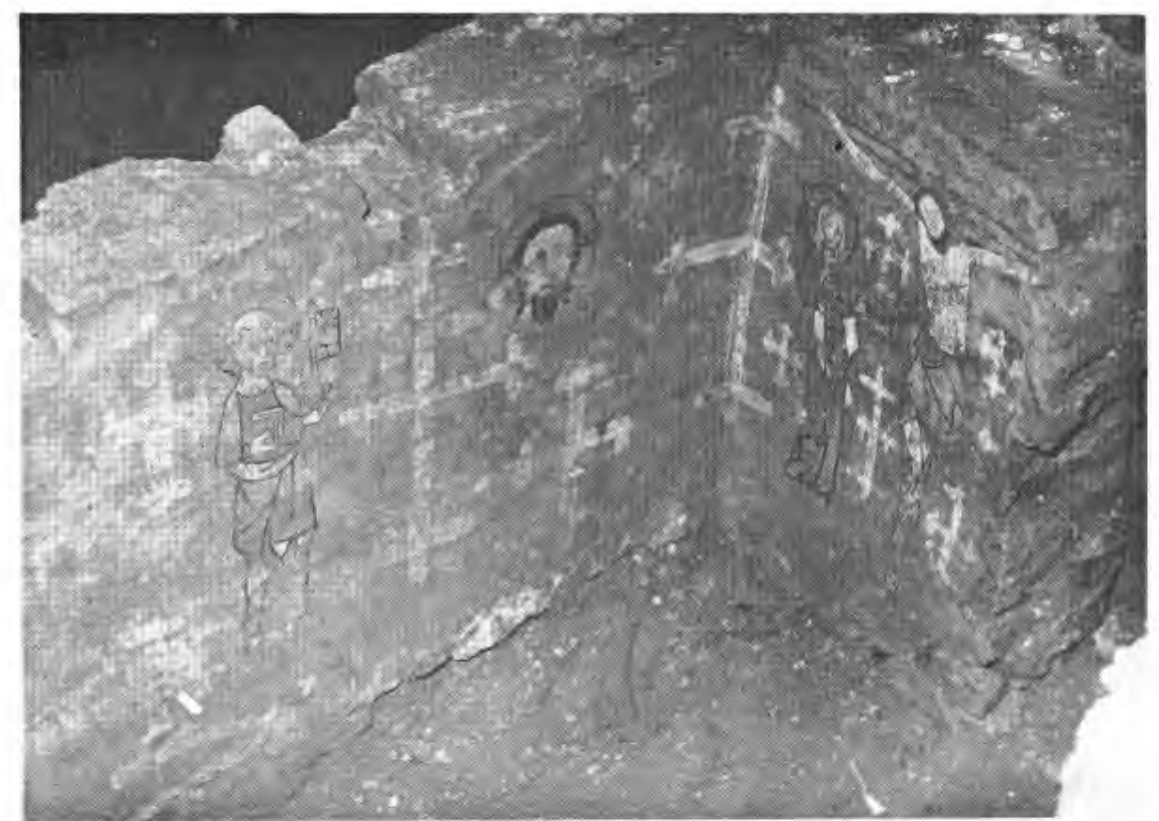

Afb. 13 - Eerste grafkelder in de noordpand

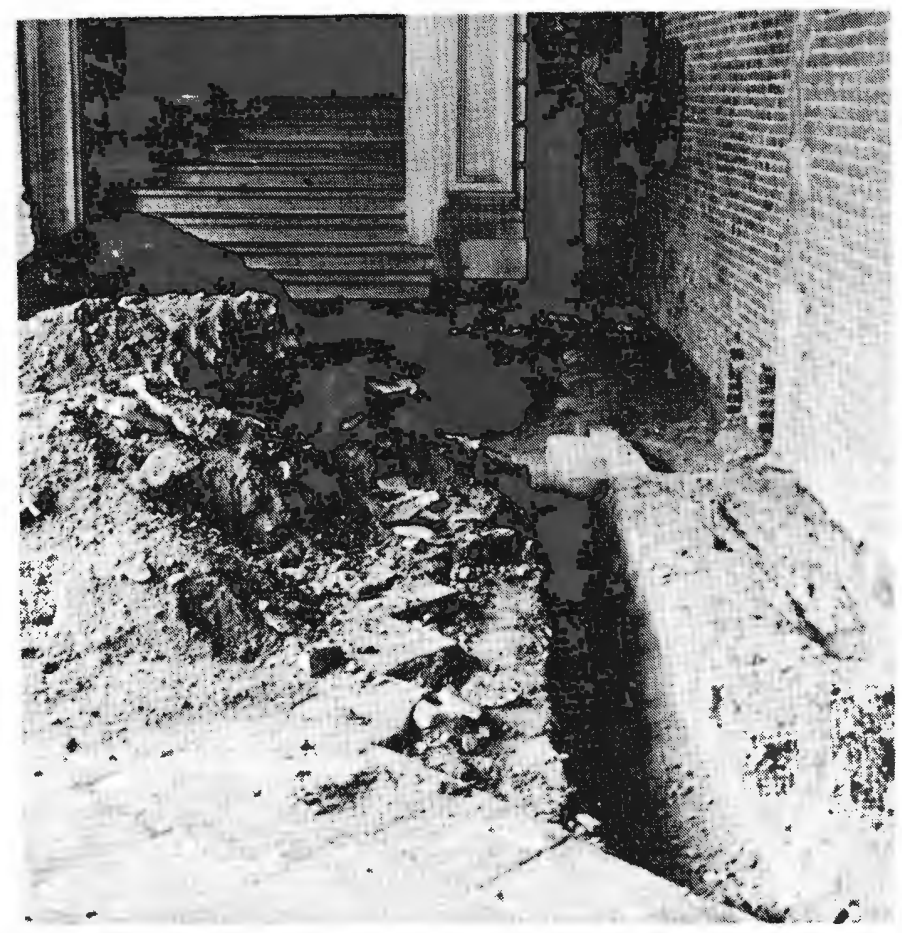

Afb. 14 - Noordpand: romaanse fundering en toegang tot de lichthof van de verdwenen kerk 


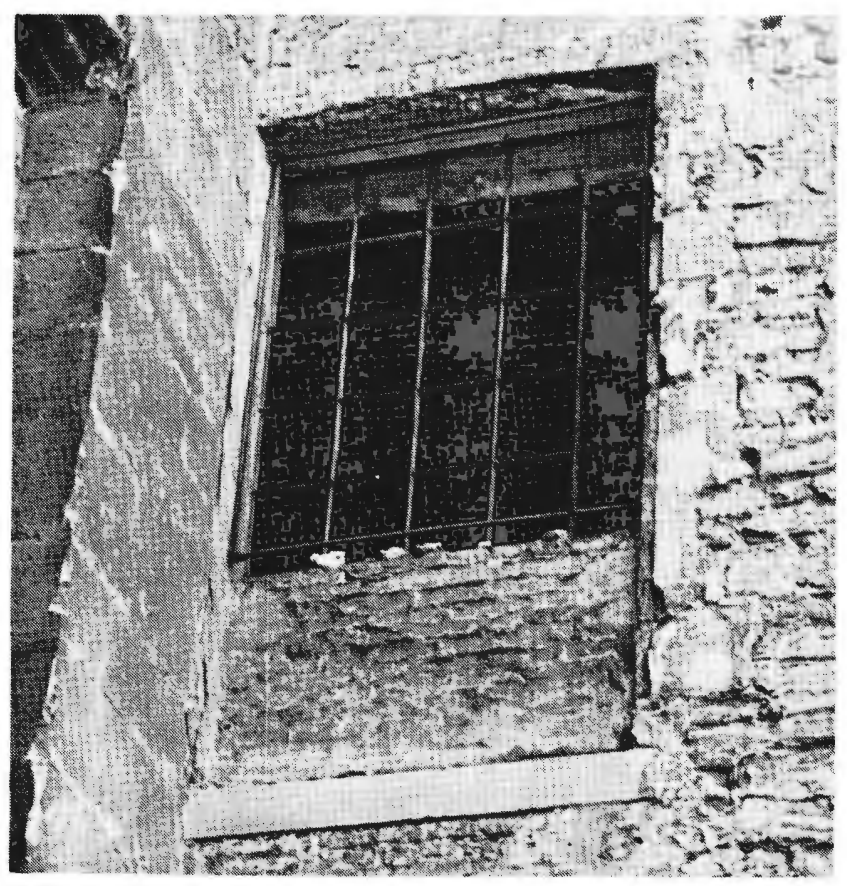

Afb. 15 - Venster in de Noordpandmuur

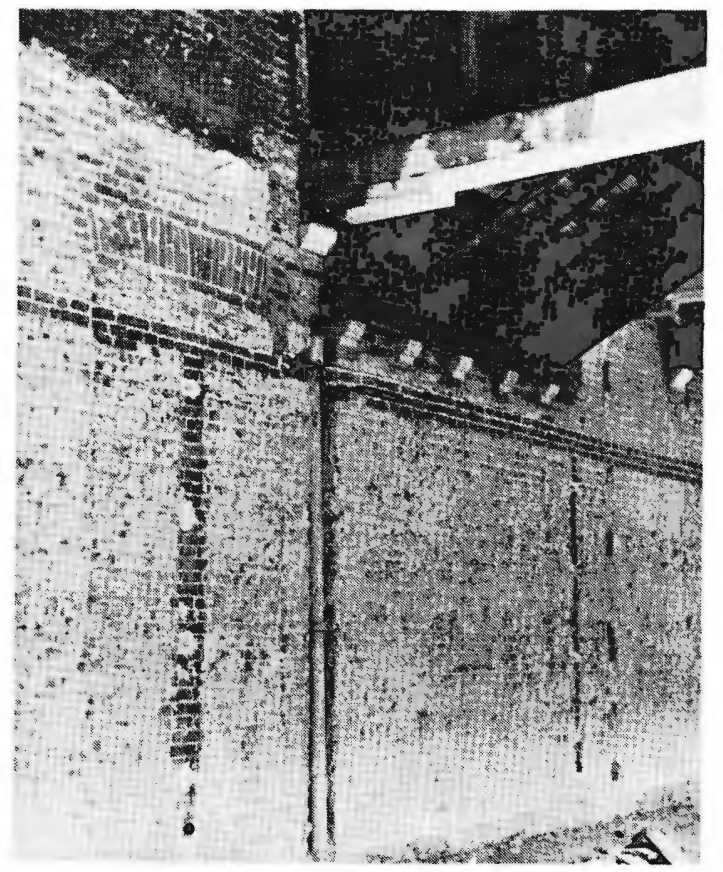

Afb. 16 - Toegemuurde vensters op de verdieping van de Noordpand 


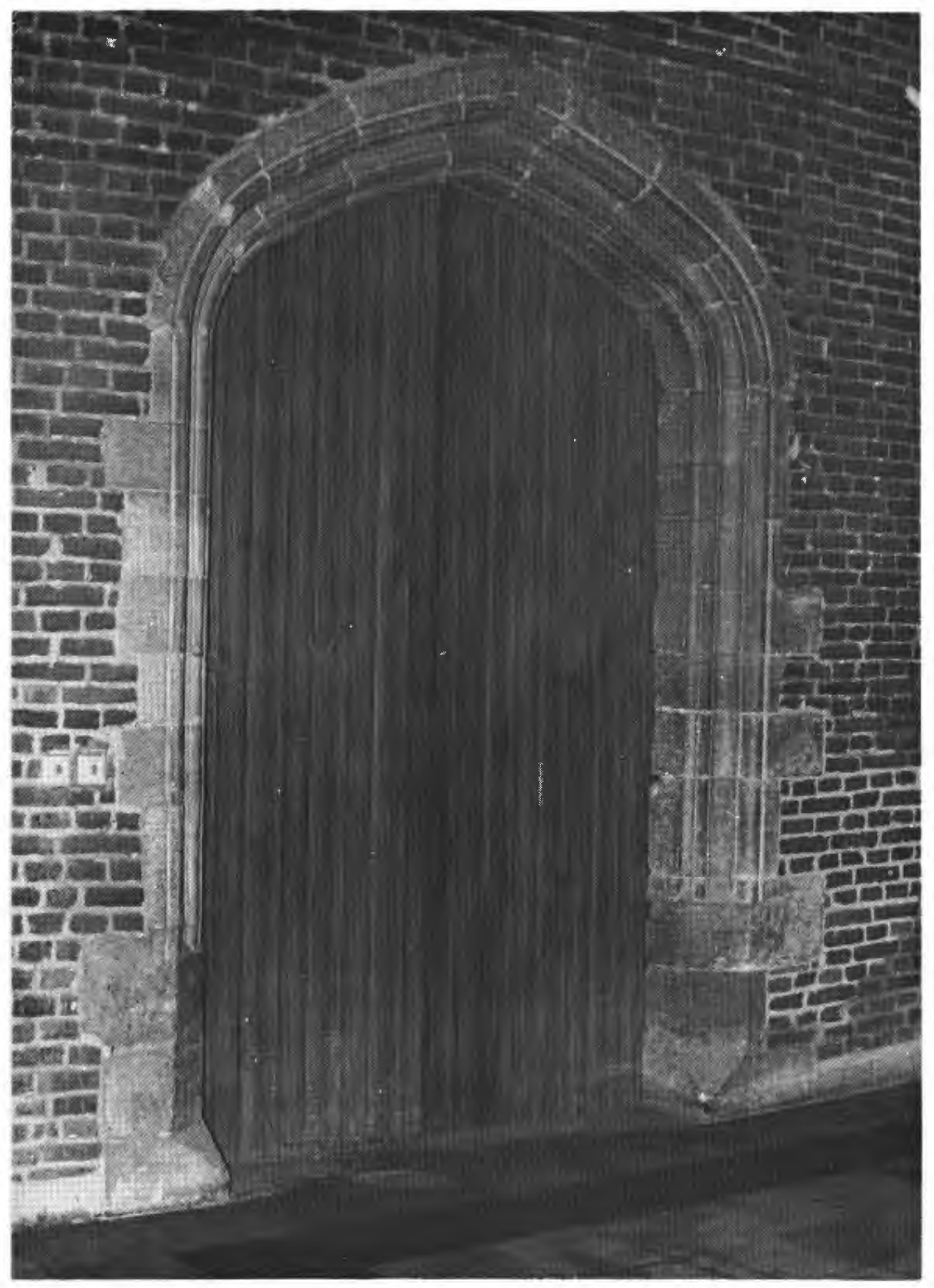

Afb. 17 - Noord-kloostergang. Toegangspoort tot de zuidzijbeuk 


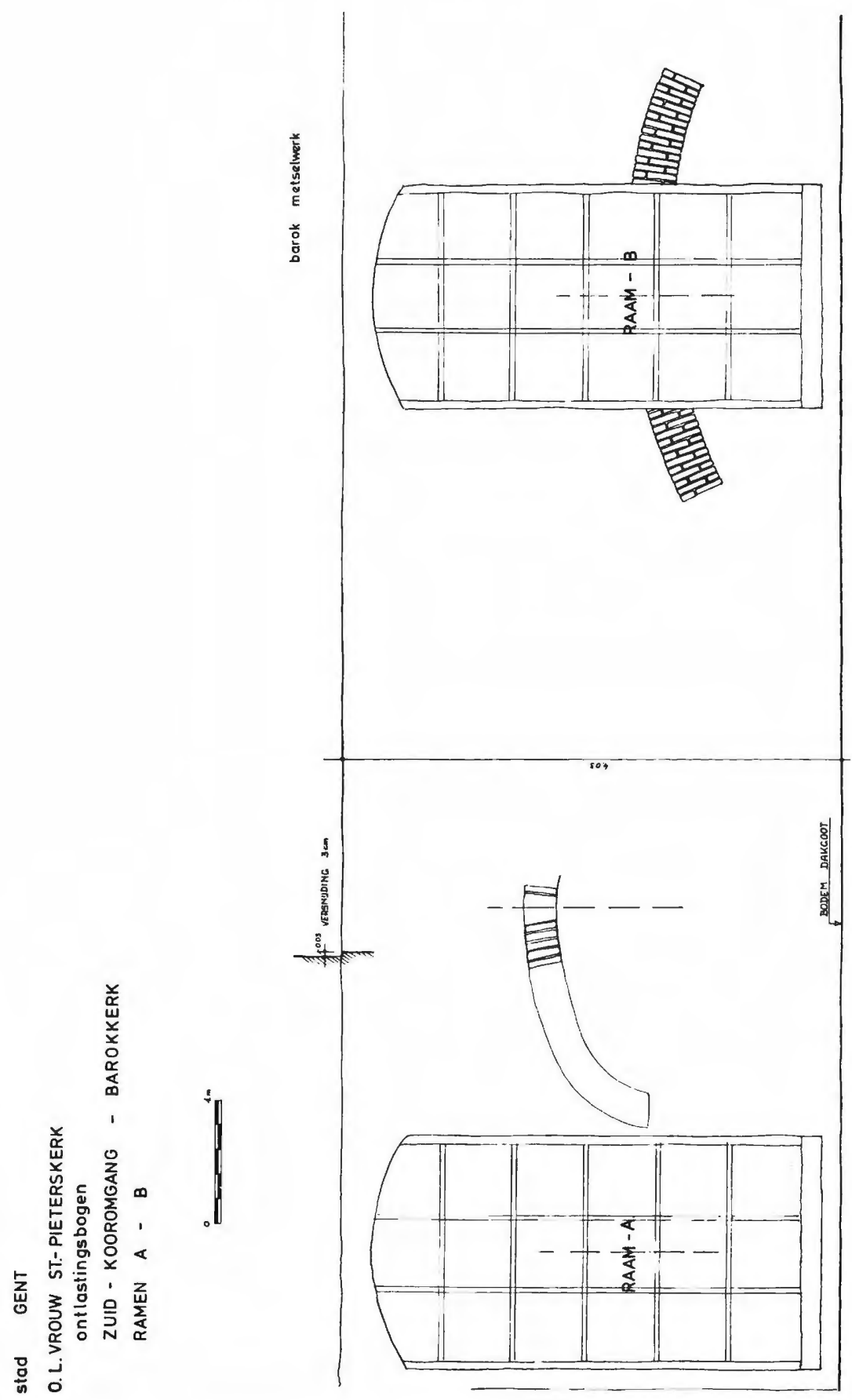

Afb. 18 - Ontlastingsbogen zuidkooromgang barokkerk naar opmetingen van Arch. Dr. R. van Driessche 


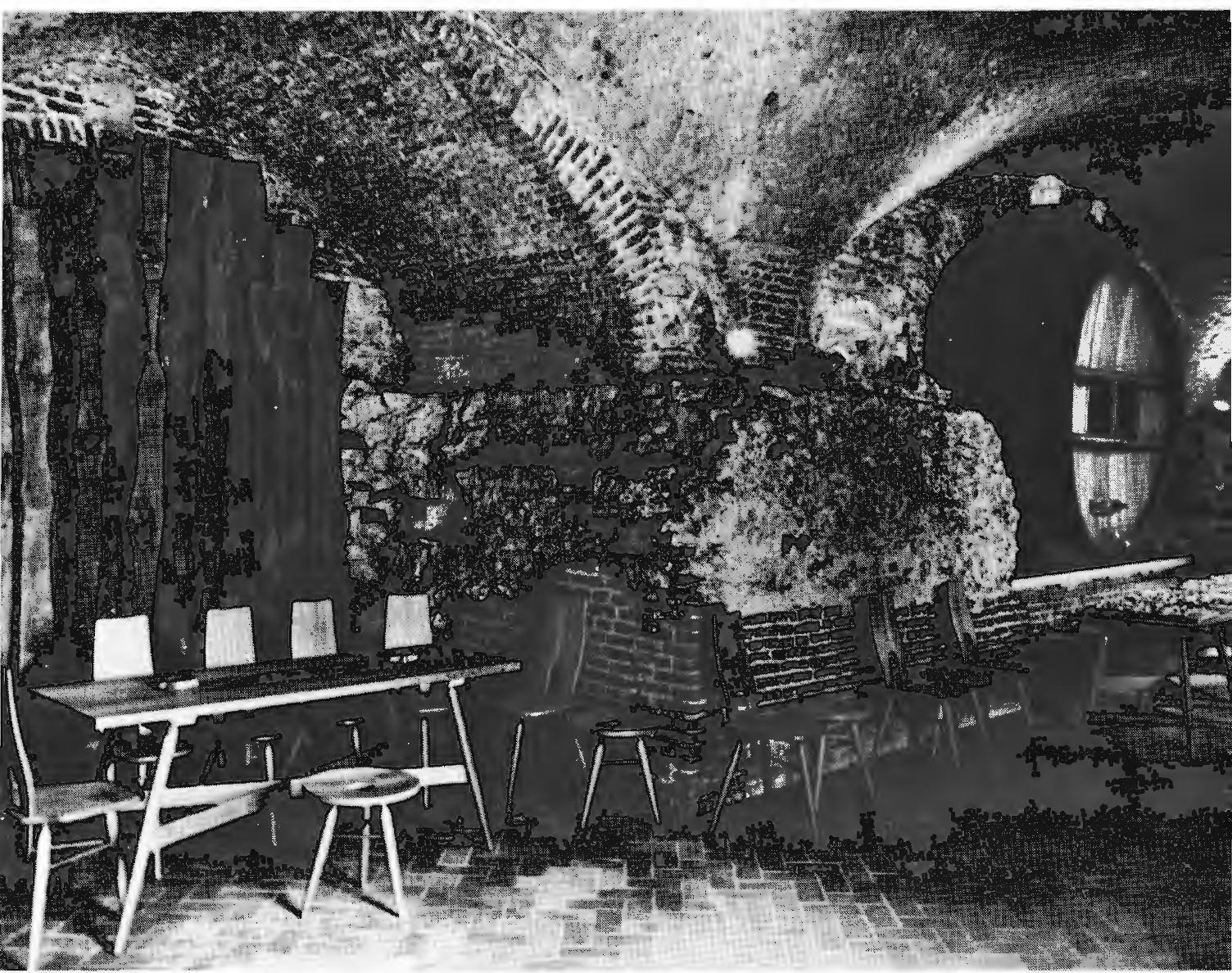

Afb. 19 - Kelder onder de zuidkooromgang van de barokkerk 


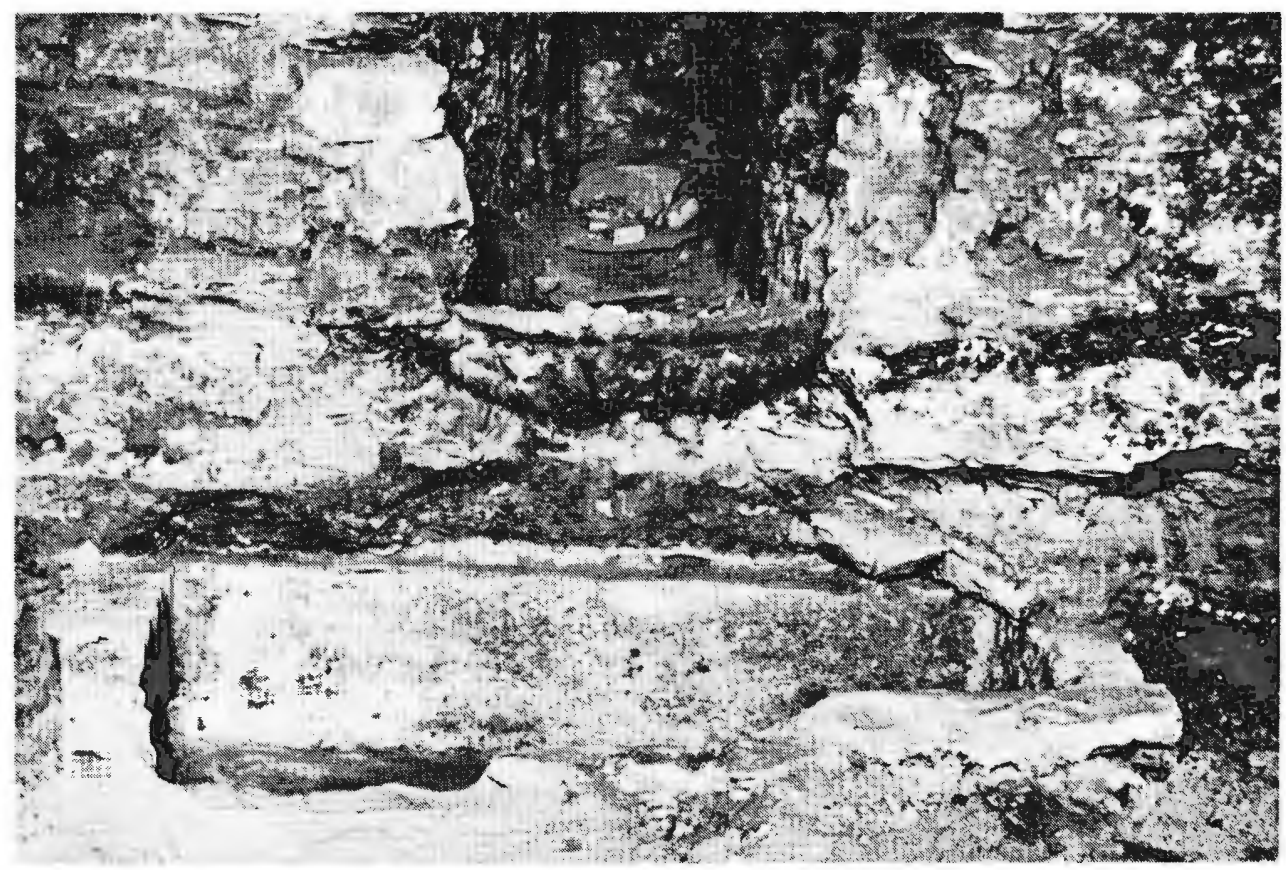

Afb. 20 - Romaanse grafkelder

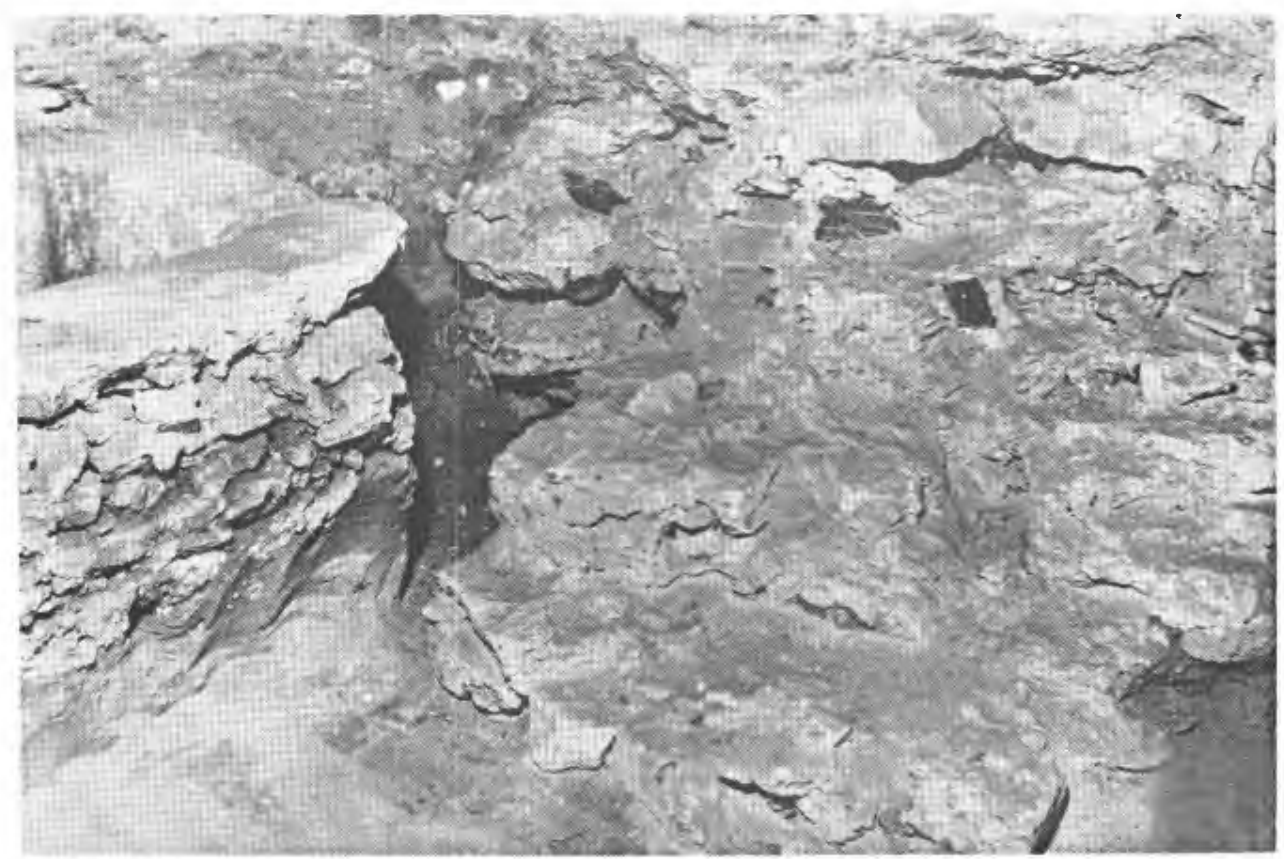

Afb. 21 - Detail romaanse grafkelder 


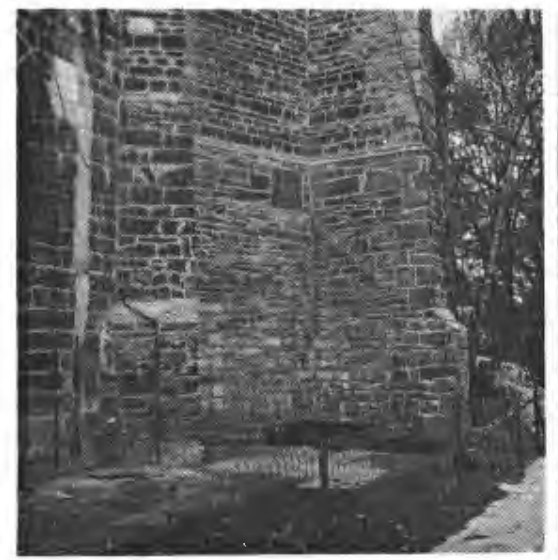

Afb. 22 - Steunberen van de O.L.V.kapel

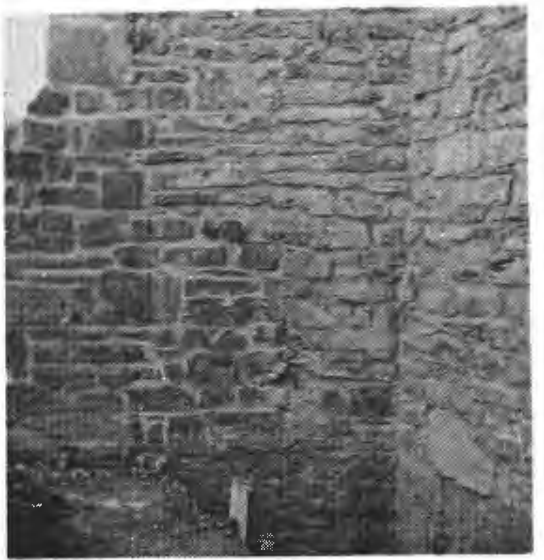

Afb. 23 - Centrale steunbeer van de O.L.V.-kapel - detail metselwerk
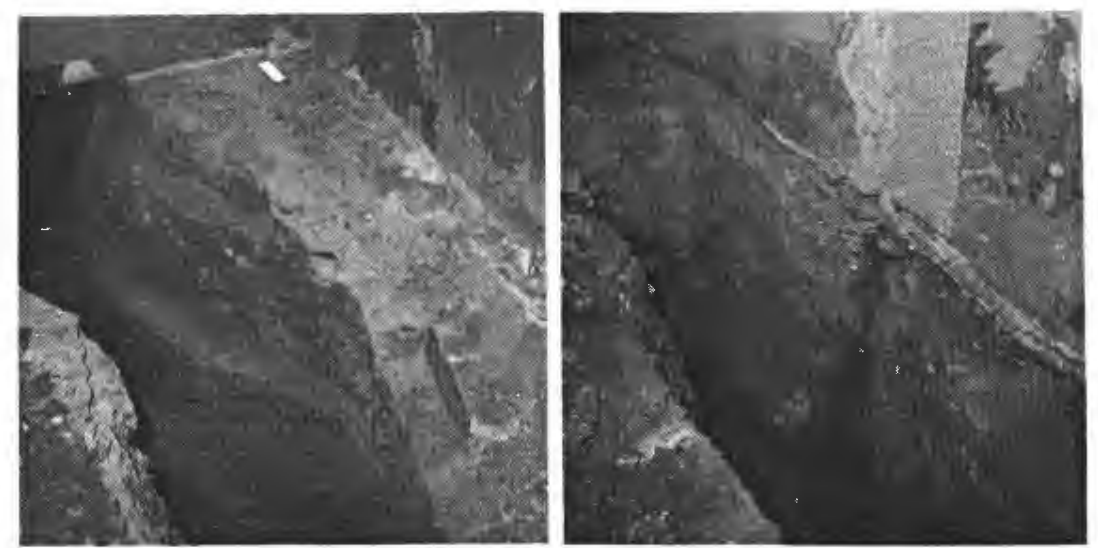

Afb. 24 - O.L.V.-kapel, resten van romaanse fundering
Afb. 25 -- O.L.V.-kapel, resten van romaanse fundering met breuk in metselwerk 
Merelbeke nog beschikte, te verkopen aan de. Wihhelmieten te Beveren ${ }^{44}$.

In 1499 werd de toren met een verdieping verhoogd;. dit om er de klokken te herbergen die voordien opgehangen waren in een afzonderlijke dakruiter. De torenhelm - zoals wij die kennen door de tekeningen van Arent van Wijnendaele - kwam maar tot stand in 1534 onder het abatiaat van Gerard van Cuelsbrouck ${ }^{45}$. Uitgerust met nieuwe vensters en een nieuw gewelf is het mogelijk dat ook de kosterij - aanliggend op de costgevel van de noordtransept - in 1503-1504 - volledig werd herbouwd samen met een stel vensters aan de noordzijde van de kerk ${ }^{46}$. .

Donkere wolken zouden zich weldra boven onze gewesten samen pakken. In de nacht van 22 op 23 oogst $1566 \mathrm{kwam}$ een opgezweepte bende van de St.-Baafskathedraal afgezakt naar de St.-Pietersabdij, waar zij hun woede botvierden zowel op gebouwen als op de inboedel ${ }^{47}$.

Omstreeks 17 juni 1567 geboden de Gentse schepenen dat iedere aangerichte schade aan kerken, kloosters en godshuizen zo vlug mogelijk moest hersteld worden.

Van zijn kant deed de Raad van Vlaanderen, zoals hoger gezegd, op 2 oktober daaropvolgend een verslag opstellen van de schade aangericht in de St.-Pieterskerk ${ }^{48}$.

Nog in de loop van ditzelfde jaar, tot en met 1576, grepen verspreide restauratiewerken plaats aan het kerkgebouw o.m. aan de kapellen van de H.H. Magdalena en Barbara ${ }^{49}$.

Wat in 1566 gespaard bleef, - of met enorme kosten werd hersteld ging door de van overheidswege stelselmatig georganiseerde inconoclastie van 1578-1579 voor een groot deel in vreemde handen over ${ }^{50}$.

Op 24 oogst 1578 - om 10 u. 's avonds - gaf de beruchte Géntse voorschepen Jan van Hembyse, het sein tot de vernieling van het kerkgebouw. Aarsthertog Matthias deed op 13 december 1578 de sloping van de kerk stopzetten. Niettegenstaande de abdij bij het stadsmagistraat eẹn eis tot schadeloosstelling had neergelegd werden de afbraakwerken in méi 1579 verder gezet. Op 30 november 1579 zakte de toren gedeeltelijk in, om - op 27 september 1580 - volledig in te storten. 'Zó verdwenen één van de prachtigste torens uit onze gewesten, die door J. Billet terecht geroemd werd onder de zeven wonderen van Gent.

Dat de kerk evenwel gedeeltelijk in gebruik bleef, blijkt zowel :uit de lokale herstellingen en de grote lening die in 1585 plaats grepen, als uît het feit dat het lijk van abt Lambert Hubeert (i582-1595) nog voor het

(44) A. van Lokeren, o.c., D.II, p. 306, nr 1962; d. 44.

(45) M. van Vaernewijck, Historie van Belgis, D.II, p. 244; C. Diericx, o.c., D.II, p. 341; P.C. vander Meersch, Memorieboek der stad Gent van 't jaer 1301 tot 1793; D.II p. 103; A. Sanderus, Gandavum, pp. 325-330; d. 45.

(46) d. 46.

(47) V. Fris, Een treurige bladzijde uit de Gentse Kunstgeschiedenis, in: B.G.O.G., Gent, 1911, pp. 100-101.

(48) V. Fris, o.c., 1.c.; d. 47.

(49) d. 48-51.

(50) R. van Driessche, Een treurige bladzijde uit de Oost-Vlaamse kunstgeschiedenis, in: Kultureel jaarboek voor de provincie Oost-Vlaanderen, Gent, 1958, D.I. pp. 94145. 
O.L. Vrouwaltaar werd bijgezet en pas veel later werd overgebracht naar de zuidpand tegenover het lavacrum.

De stormschade aangericht aan het Grijspeerentorentje - staande rechtover de Bagattenstraat - wordt trouwens in 1586 nog vermeld. Bij bulle van 9 februari 1589 verleende paus Sixtus V aan de Pieterlingen het recht tot incorporatie van de O.L. Vrouwparochiekerk. Recht, dat evenwel door de pastoor en de kerkraad werd betwist en door de Raad van Vlaanderen werd verbroken. Ook in het eerste kwart van de 17 e eeuw grepen an de geteisterde kerk nog herstellingen plaats ${ }^{51}$. De Utrechtenaar Arseen van Schayck, abt geworden in 1615, zal in 1628 het startsein geven voor het bouwen van de barokkerk ${ }^{52}$.

\section{GRAFISCHE BRONNEN}

Naast de litteraire bronnen bestaan er ook enkele grafische die ons inlichten over de verdwenen abdijkerk.

De tot op heden enig bekende afbeelding van de westgevel komt o.i. voor op een zegel ${ }^{58}$ uit het jaar 1321 (afb. 1). Getooid in liturgisch gewaad - de staf in de hand - staat abt Fulcro de Rijcke (1320-1337) in het portaal van zijn kerk. Dit bestaat uit een smalle twee registers hoge nis die overtopt wordt door een accoladeboog waarboven een tympaan zichtbaar is, dat eveneens afgedekt wordt door een accoladeboog. In het bovenregister wordt de "Nood Gods" voorgesteld. Men ziet de H. Maagd zetelend op een brede troon waarvan het onderstel bestaat uit een lage - met nissen opengewerkte - bank, terwijl het rugpaneel omzet is met pinakelvormige elementen.

De dagkanten van het portaal zijn omgeven door een met hogels versierde rondlopende rolstaaf. Aan weerskanten wordt deze nis geflankeerd door dubbele driemaal versnijdende gotische steunberen waarvan de onderste geleding bestaat uit in verband gemetselde laaghoogten en de volgende twee voorzien zijn met zgn. "vensterwerk". Als bekroning dient een drieledig bouwsel dat in het midden hoger is, en afgedekt wordt door een driehoekig dak of gevelveld. De muren zijn ingedeeld door lisenen waartussen zich vensters of blindnissen bevinden. Schijnbaar is dit de opstand van de kerk, bestaande uit een lage vierkante lantaarntoren waarbij de beuken aanleunen. Alles wijst erop dat men hier niet te doen heeft met een gefantaseerd werk, maar wel met dit gedeelte van de kerk zoals het was ten tijde van abt Fulcro, nog vóór het door de zware branden van

(51) B. de Jonghe, Gendsche Geschiedenissen, Gent, 1781, D.II., pp. 43, 93, 128, 194, 202, 244; E. de Busscher, Notice sur l'abbaye de Saint-Pierre à Gand, pp. 56, 57; J. van de Vivere, Chronycke van Ghendt, uitgave: Frans de Potter, Gent, 1885, pp. 300, 304, 305, 380; Juste Billet, Poulitye Boucke, stadsarchief Gent; hs. D.I. p. 157; A. van Lokeren, o.c., D.II., p. LXXVI; d. 52-60.

(52) A. van Lokeren, o.c., D.I. p. IV.; R. van Driessche, Bouwgeschiedenis der Barokke St-Pietersabdijkerk te Gent, in: Handelingen van het $6^{\circ}$ Congres voor Algemeene Kunstgeschiedenis, Gent, 1942, pp. 66-90.

(53) Stadsarchief van Gent, Charter $\mathrm{nr} \mathrm{68,} \mathrm{in:} \mathrm{Katalogus} \mathrm{religieuse} \mathrm{kunst} \mathrm{in}$ Oost-Vlaanderen, Gent, $1951 \mathrm{nr} 78$. 
het midden der 14 de eeuw werd geteisterd.

Zegels of munten waarop gebouwen voorkomen behoorden niet tot de zeldzaamheden. Het moge volstaan te verwijzen naar deze waarop in de $13 \mathrm{de}$ en de $14 \mathrm{de}$ eeuw de St.-Pieterskerk te Leuven en de St.-Michielskathedraal te Brussel ${ }^{54}$ voorkomen. Andere afbeeldingen van de voormalig abdijkerk zijn ons pas uit de 16 de eeuw bekend. Zij werden reeds vroeger vrij uitvoerig bestudeerd ${ }^{55}$ zodat wij ons ontslagen achten hierop diep in te gaan.

De boutgravure in 1524 gemaakt door Pieter de Keysere - 27,3 x 9,2 $\mathrm{cm}$ - toont ons uiterst links de St.-Pieterskerk (afb. 2). Zij wordt afgebeeld met kloeke vierkante lantaarntoren op de viering, die voorzien is van een arkeltorentje en misschien wel van trapkokers. De muurvlakken zijn doorbroken met langgerekte vensters. Dit zou er kunnen op wijzen dat de toren zijn romaans uitzicht had behouden, wat o.i. niet mogelijk is, gezien Laurens van der Leyen in 1398 belast werd met de uitvoering van een nieuwe toren waarvan de werken drie jaar hebben geduurd. Op het dak van het schip - dat lager is dan dat van het koor - staat een vlak afgedekte dakruiter. Het koor is polygonaal gesloten.

Een weinig jonger is de pentekening op wit papier - 12,7 x 18,7 cm uit de collectie Clifford-Duits te Londen ${ }^{56}$. Op deze tekening — waarvan de versozijde blanco is gebleven - gemaakt vóór 1534 komt de oostzijde voor van de kerk en de abdijgebouwen samen met de parochiale O.L. Vrouwkerk. De latere tekeningen van Arent van Wijnendaele sluiten aan bij deze tekening, zodat het ons overbodig lijkt ze hier aan een grondig onderzoek te onderwerpen.

In de Codex Iconograpbicus nr 2645 bewaard in de Koninklijke bibliotheek te München komt een panorama voor van de stad Gent dat door Armand Heins op steendruk werd overgebracht ${ }^{57}$.

Al deze tekeningen hebben misschien gediend voor het schilderij $1,72 \times 1,36 \mathrm{~m}$. - kort vóór 1540 gemaakt en dat nu in het museum van de Bijloke te Gent berust. Volgens de traditie zou dit tafereel een kopij zijn van een schilderij van Lucas d'Heere. Het toont ons Gent zoals de stad er ongeveer moet uitgezien hebben voordat de St.-Baafsabdij op last van Karel V in 1540 gedeeltelijk werd gesloopt.

Naar het plan in 1551 gemaakt door Jan Oste, kent men een Yylogravure (afb. 3) waarop de kerk te zien is met een transepttoren bekroond met een peervormig dak. Een groot raam doorbreekt de westgevel; de kruisbeuk is lager en schijnt - ten noorden - geflankeerd te zijn door een trapkoker ${ }^{58}$.

(54) R. Lemaire, Les origines du style gothique en Brabant, Brussel 1906, pp. 87-89; C. Leurs, idem, Brussel, 1922, p. 54.

(55) M. Deruelle, o.c., pp. 42-46.

(56) J.Q. van Reegteren Altena, in: Opus Musivum Professor Doctor M. Ozinga, Assen, 1964, pp. 161-171.

(57) A. Heins, Vue panoramique de Gand 1540, Codex iconographicus, 265, Münich, Gent, 1915.

(58) P. Bergmans, V. Fris en V. van der Haeghen, Documents Topographiques relatifs à la ville de Gand, XVIe et XVII' siecles, D.II, Gent, z.d. p. 5; V. Fris, Plans de Gand, Introduction aux documents topographiques, Gent, 1920, pp. 19-20. 
Gewichtiger voor de studie van de verdwenen kerk zijn de tekeningen gemaakt in 1560 door Arent van Wijnendaele. Priester Weemaes maakte er in 1768 copijen van die nu berusten in het British Museum te Londen ${ }^{50}$ en die opeenvolgend voorstellen:

nr 13 - De Kerke en Abdije van St.-Pieters op de westzijde

nr 14 - De Kerke en Abdije van St.-Pieters langs den kant van de Schelde... of te Noord-Syde (sic) door Mtr Arent van Wijnendaele... ten jare 1580 .

Het is niet uitgesloten dat $\mathbf{N}$. Heins voor het werk van A. van Lokeren „Chartres et documents de l'Abbaye de St-Pierre" circa 1868 de originele tekeningen van Arent van Wijnendaele gecopieërd heeft ${ }^{60}$. Latere tekeningen die teruggaan op deze van Heins zijn voor ons van weinig of geen belang en mogen derhalve achterwege worden gelaten.

Een laatste grovure waarop de kerk tamelijk goed staat afgebeeld is deze van Braun en Hohenberg uitgevoerd in 1576 en getitelt "Civitates orbis terrarum" 61.

Uit de gekende afbeeldingen blijkt dat aan de - zeer vaag weergegeven - westgevel geen torens voorkwamen. Dit sluit evenwel het bestaan van een torenpartij nog niet helemaal uit.

Volgens de tekeningen van Arent van Wijnendaele, behoorde de kerk tot het basilikaal type (afb. 4) met dubbel transept, vieringstoren en transkapellen. De westgevel van de kerk wordt volledig gemaskeerd door een gebouwenkompleks dat boven de nok van de hoge lichtbeuk uitreikt. Vijf brede - met een korfboog afgedekte - zesdelige vensters doorbreken de langsmuren van de zijbeuk alsmede die van de hoge lichtbeuk.

De traveeën van de onder een lessenaardak staande zijbeuk worden gescheiden door zware - versnijdende - steunberen. Bij de hoge lichtbeuk worden de traveeën gemaskeerd door lisenen.

De noordtransept - even hoog als het schip — wordt doorbroken met een zesdelig van maaswerk voorzien gotisch venster, waarvan de ontlastingsboog - in tegenstelling met deze van het schip - bestaat uit een puntboog. Pinakels bekronen de dubbele hoekfrijten. De gevel voert een kruisbloem ten top. Tegen de westwand bemerkt men een uitkragende cirkelvormige trapkoker. Zowel het schip als het transept staan onder zadeldaken. Boven de dakgoot loopt een eenvoudige metalen balustrade. Aanleunend bij de oostmuur van de transept bevinden zich enkele lagere gebouwen.

De prachtige - twee verdiepingen tellende - hoge transepttoren is onderaan vierkantig en bovenaan achtkantig. Octogonale traptorentjes flankeren de vlakken van de beneden geleding. Dit kan het gedeelte zijn door van der Leyen op het einde van de 14 de eeuw begonnen. Deze vier vakken hoge trapkokers, verlevendigd door smalle nissen, worden onderling verbonden door een opengewerkte balustrade. Iedere koker bezit een peervormig dak in de zin als dit van de transepttoren. De hoektorentjes worden

(59) A. van Lokeren, Universiteitsbiblioteek Gent, ms, G. 11763.

(60) A. van Lokeren, o.c., D.I, pp. 1-2.

(61) G. Braun en Fr. Hohenbergius, Civitates orbis terrarum, Coloniae Agrippinae, 1576, p. 15. 
beëindigd door een smeedijzeren kruis, staande op een bol. In de muurvlakken van het benedengedeelte van de transepttoren openen zich tweeledige vensters die gescheiden worden door een muurdam. Dubbele hoekfrijten zonder versnijding betonen de achtkantige torengeleding waarvan de muurpanden voorzien zijn van grote vensters waarin galmborden zijn aangebracht. Boven het peervormig dak - met op de ingezwikte dakschilden dakkapellen - verheft zich het lelievormig kruis. Het octogonale gedeelte stamt vermoedelijk uit het einde van de 15 de eeuw en de bekapping uit de eerste helft van de 16 e eeuw.

Het koor - even hoog als de beuk - wordt verlicht door een rij van driedubbele aaneengeschakelde rondbogige vensters die wel zullen omlijst zijn geweest door enigzins bredere op zuiltjes samenvallende bogen.

Een korbeellijst fungeert als aanzet van het dak waarop de lage - vlak afgedekte - vierkantige klokkentoren prijkt.

Op de langsmuren van de kooromgang bemerkt men de pseudo transept waarvan de nok onder de vensters van de buitenloopgang van de hoge lichtbeuk .van het koor blijft. Deze gereduceerde transept maakt het bindteken uit tussen de kooromgang en het klaverbladvormig koorhoofd.

In de as van de kerk opent zich de O.L. Vrouwkapel (afb. 5) die polygonaal gesloten is en door drie massieve steunberen in vier vakken wordt gescheiden. Corlonlijsten verdelen deze kapel horizontaal in vier registers waarvan de onderste vrijwel het voornaamste is.

Opmerkenswaardig is het feit dat hier vensterloze rondbogig afgedekte blindnissen worden aangegeven. Daarentegen komen in de hogere, twee geledingen vrij brede vensters voor, waarvan deze uit de bovenste voorzien zijn van een rondlopende onderling verbonden waterlijst.

Let tevens op de grote zorg die hier door de tekenaar werd aan de dag gelegd o.m. bij het weergeven van de onderverdeling en de afdekking van de versnijdingen bij de steunberen en de korbeellijst aan de voet van het dak.

Mocht het register met de blindnissen samen met het daarbovenliggend vak tot een ruimte behoord hebben - waarboven dan de zgn. "Triniteit" kwam - dan zou de krypte nog lager dienen gezocht te worden. Dergelijke hypothese verwijzen wij naar het rijk der verbeelding. Eerder denken wij dat bij de uitbreiding van het koor en het bouwen van de O.L. Vrouwkapel in 1216, de krypte niet werd vergroot maar eerder a.h.w. door de nieuwe konstruktie werd opgeslorpt. Alleen ernstig doorgevoerde bodemprospectie is bij machte antwoord te geven op de vraag of zij in de ondergrond van de huidige kerk nog bestaat.

\section{HET RODEPLAN}

Een uiterst gewichtig document voor de kennis van de voormalige kerk is het zgn. "Rodeplan" (afb. 6) dat bewaard wordt in het rijksarchief te Gent ${ }^{62}$.

(62) P.C. van der Meersch, Inventaire des Cartes et Plans conservés aux Archives de Flandre-Orientale, Gent, 1850, nr. 205. 
In rode inkt getekend op papier en geplakt op lijnwaard draagt het als titel „Audt Clooster en Abdye van St-Pieters". Te oordelen naar het geschrift en het woord "colationné" dat er op voorkomt, lijkt het ons te zijn een 18de eeuwse copij naar een veel ouder verloren geraakt plan. Vensteropeningen ontbreken, hetgeen aan de tekening een primitief karakter verleent.

Van dit, voor onze studie zo belangrijk plan, bezit het stadsarchief te Gent een met nota's voorziene copie van A. van Lokeren. Aan de hand van de hoger besproken tekeningen van Arent van Wijnendaele werden o.m. in de buitenmuren van het laatst genoemd plan, vensteropeningen aangebracht.

Dit plan diende als klad voor een derde, eveneens in het stadsarchief te Gent, dat in de eerste helft van de 19de eeuw werd gemaakt door een ervaren tekenaar ${ }^{63}$.

De zaak wordt spannend als men weet dat abt Amandus Hovelinck (1657-1679) voor de Raad van Vlaanderen in 1672 een proces voerde tegen de pastoor van de O.L. Vrouwkerk in verband met het vernielen van de hekken tussen de abdij en het kerkhof ${ }^{64}$.

Hieruit blijkt dat — alvorens de oude kerk werd afgebroken (vóór 1628) van geheel het abdijkompleks een grondplan werd opgemaakt. Dit plan dat in het procesbundel ontbreekt - zou o.i. kunnen gediend hebben voor het maken in de 18 de eeuw van het zgn. „Rodeplan" ${ }^{85}$.

Volgens het „Rodeplan" werd tegenaan de westgevel een gebouwenkompleks opgericht bestaande uit: ten noorden de prelatuur, waarvan het gedeelte palend aan de kerk bestond uit een ruim lokaal getiteld „abdije" dat ten westen voorzien was van een halfronde trapkoker, ten zuiden uit de "Groote salette", ten wensten voorzien van een rechthoekige trapkoker. In een open koer lag in de nabijheid een natuurlijke bron.

De benedenkerk bestond uit een vijf traveeën diepe middenbeuk aan weerskanten geflankeerd door zijbeuken van ongelijke breedte. Tussen het schip en het koor werd een assymetrisch transept ingeschakeld.

Het vier en half traveeën diep koor bevatte een middenbeuk met halfronde sluiting omgeven door een kooromgang. Zowel de noord- als de zuidzijde van de kooromgang werden bijna volledig bezet door een reeks aanbouwen.

Aan de zuidzijde was gedeeltelijk een pseudo-omgang voorhanden, waarboven zich de bibliotheek bevond. Verder werd aan die zijde de SintBenediktuskapel aangetroffen met aanpalende sacristij met op haar verdieping de tresorie.

De kosterij met aanliggende kapel van de abt, alsmede de Sint-Denijskapel vormden de aanbouw op de noordelijke kooromgang. Halverwege de vierde koortravee werd de gereduceerde transept aangebracht.

Apsidiolen - waarin de kapellen van de H.H. Johannes en Amelberga - vormden de overgang van de kooromgang naar de klaverbladvormige

(63) M. Deruelle, o.c., pp. 5, 40, 41, 42.

(64) M. Deruelle, a.c., ppi. 5, 40, 41, 42.

(65) doc. 61. 
O.L. Vrouwkapel, symbool van de Goddelijke drieëenheid. Vestigen wij hier vooral de aandacht op de polygonale sluiting van kwestige kapel. Inderdaad, deze bestaat uit de vier zijden van een ingeschreven zevenhoek. Iconografisch zou dit in verband kunnen gebracht worden met de Zeven Vreugden en de Zeven Smarten van Maria aan wie de kapel toegewijd was.

Uit de generale rekeningen weet men bepaald zeker dat de huidige O.L. Vrouwkapel in 1628 gebouwd werd op de oude funderingen. Dit laat ons toe de as van de voormalige kerk vrij nauwkeurig te bepalen.

Aan de hand van het „Rodeplan” kan o.m. worden uitgemaakt dat de gesloopte kerk zeker een travee uitsprong op de westkloostergang. De westgevel kwam dus ongeveer ter hoogte te liggen van de westgevel van de nog steeds bestaande oude refter. Dit schijnt Deruelle o.m. niet opgemerkt te hebben bij de restitutie van het grondplan van de middeleeuwse kerk ${ }^{66}$.

Volgens de beschrijving die de Franse diplomaat François Baudot ons circa 1623 van de St.-Pietersabdij geeft, zou de lengte van de toen reeds afgebroken kerk 862 voet (sic) geweest zijn, waarbij de voet onderverdeeld werd in negen duim ${ }^{67}$. Naar onze mening werd hier voor het eerste cijfer een schrijffout begaan en zou er inplaats van 8 , drie moeten gestaan hebben, wat voor de totale lengte dan 362 voet zal zijn geweest.

Onder de menigvuldige nota's door A. van Lokeren aangebracht op een copy van het "Rodeplan" leest men evenwel: "J. Vanchard 1480 Annus reddities ecclesie S. Petri - Die choor't Sinte Pieters es lang 160 voete, breed 41 voete; elke side: boven 33 stalle (voor de paters), beneden 28 stalle (voor de broeders)".

Uit de laatste twee geciteerde documenten kent men dus o.m. de onderverdeling van de voet in negen duim, de lengte en de breedte van het koor en het aantal koorzetels. Dit laat ons toe te veronderstellen dat al deze gegevens binnenwerks dienen te worden gezien ${ }^{68}$. Als interpretatie van het "Rodeplan" stellen wij derhalve het volgende schema voor (afb. 7), rekening houdend met een vermoedelijke dikte van $1,00 \mathrm{~m}$, voor muren en pijlers:

voet $=2,753 \mathrm{~cm}$. duim $\times 9=24,777 \mathrm{~cm}$.

lengte $=24,777 \mathrm{~cm} . \times 160$ voet $=39,65 \mathrm{~m}$.

Koor: Breedte $=24,777 \mathrm{~cm} . \times 40$ voet $=9,91 \mathrm{~m}$.

Module voor traveeën $10,16 \times 8,00 \mathrm{~m}$.

Module kooromgang $5,08 \times 4,00 \mathrm{~m}$.

Voor het bepalen van de module van de benedenkerk werd gebruik gemaakt van de afmetingen van de nog bestaande korfboog in de eerste travee van de noordpand (afb. 8) die eertijds toegang verschafte tot de lichthof

(66) M. Deruelle, o.c., pp. 67-68.

(67) René Gaspar, Documentaire gegevens over het geestelijk leven, enkele adbijen en kerken met hun relikwieschatten in de Spaanse Nederlanden, in: Ons Geestelijk Erf, Antwerpen 1937, D.XI, afb. 4, pp. 326-359.

(68) R. van Driessche, Een bijdrage tot de bouwgeschiedenis van de St-Pietersabdij te Gent, in: Handelingen van het 22ste Vlaams Filologencongres, Gent, 1957, pp. 329-332. 


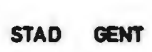

O. L.VROUW ST.-PIETERSKERK

PROEVE TOT RESTITUTIE van do

ROMAANS - GOTISCHE PLATTEGROND
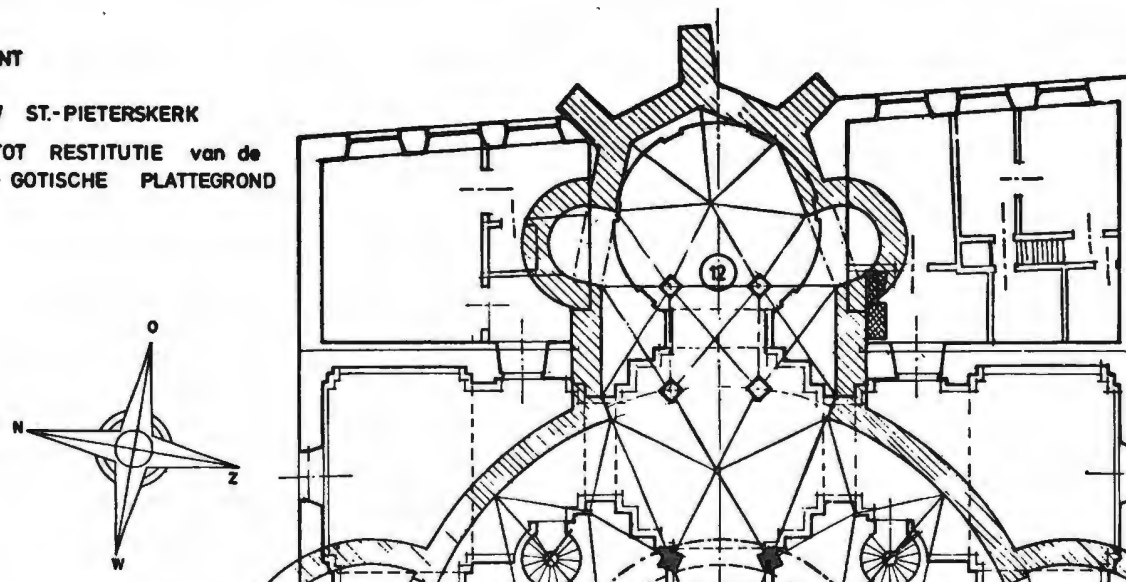

䙹—

- 14 in

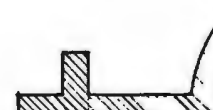

(1)

O 1
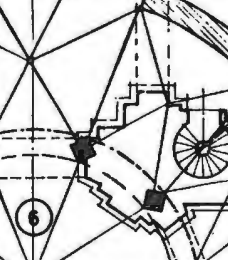

(10)
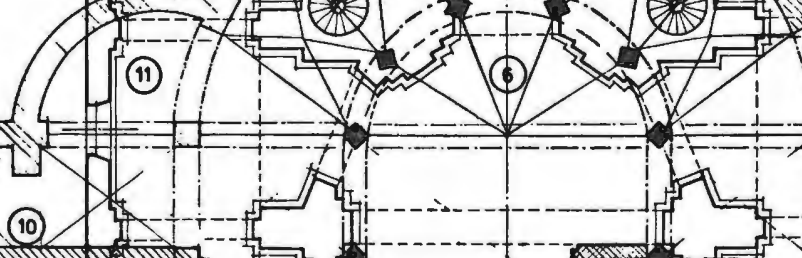

(3)

艺

2
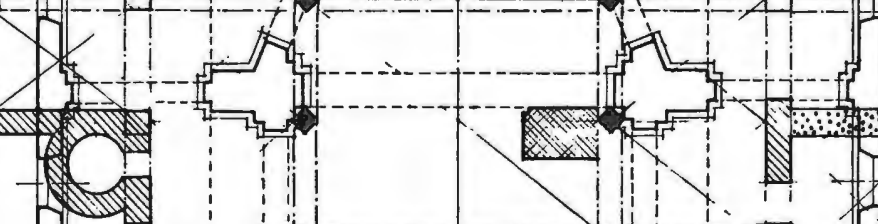

(1) $>$

i

$\frac{1}{4} \sqrt{1}$

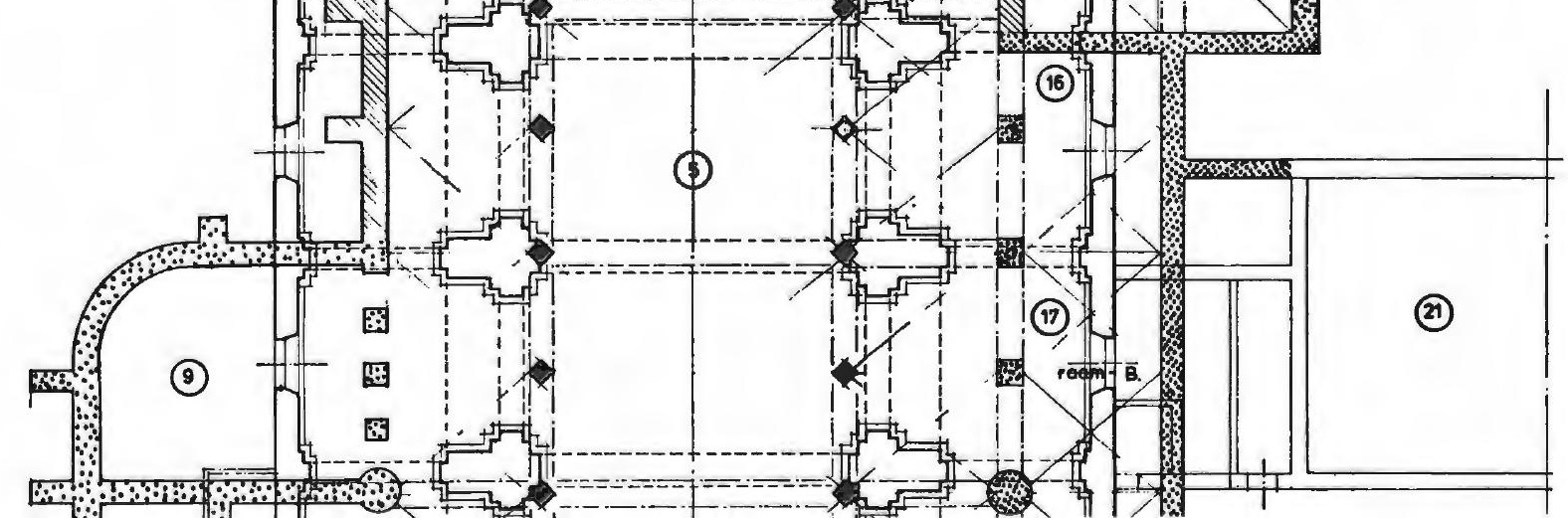




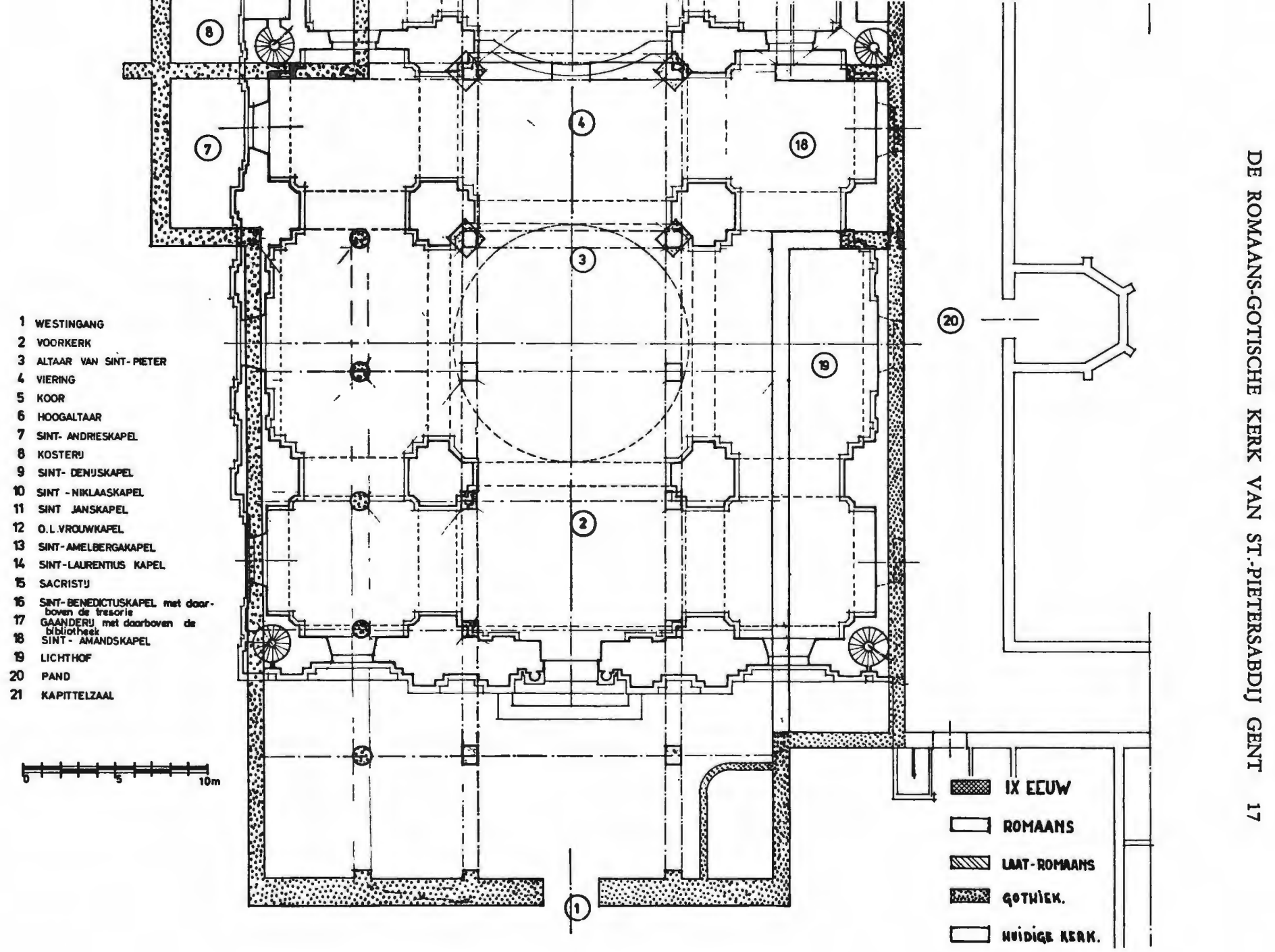


palend aan de zuidzijbeuk van de kerk en die nu voor een groot gedeelte verdwijnt achter de muur van de eerste travee van de zuidzijbeuk van de barokkerk.

Zij voor het Schip: $10,16 \times 8,00 \mathrm{~m}$.

en voor de Kooromgang: 5,68 x 3,50 m.

Dit geeft voor de benedenkerk vijf traveeën van $10,16 \mathrm{~m}$. x $6,00 \mathrm{~m}$. met een totale lengte van $35,00 \mathrm{~m}$.

Indien men voor de kruisbeuk een module neemt van 10,16 m. x 8,00 m. komt men voor de totale afmeting van de verdwenen kerk tot volgend resultaat:

\begin{tabular}{lc} 
lengte: & koor \\
\multicolumn{1}{c}{ schip } & 39,65 \\
transept & 35,00 \\
kooromgang & 8,00 \\
O.L. Vrouwkapel & 5,08 \\
muren en steunen & 8,50 \\
& 6,50 \\
\cline { 2 - 2 } Totale lengte & $102,73 \mathrm{~m}$. \\
Breedt benedenkerk & $30,40 \mathrm{~m}$. \\
Transept & $41,50 \mathrm{~m}$. \\
pseudo-transept & $46,50 \mathrm{~m}$.
\end{tabular}

De vorm van de huidige kapittelzaal schijnt ons volledig te kloppen met de configuratie van het „Rodeplan”. In dit geval zou de breedte van de kapittelzaal overeenstemmen met de derde en de vierde travee van het "Rodeplan" wat niet helemaal past in onze restitutie. Hier dient eveneens opgemerkt dat de westmuur van de pseudo-transept - waarin zich respectievelijk de Sint-Niklaas- en de Sint-Laurentiuskapel bevonden op het "Rodeplan" - ongeveer begint in het midden van de travee die de koorsluiting voorafgaat; $\mathrm{zij}$ op ons plan bij de achtste travee.

Indien zo, dan komt men voor de sacristij - aanliggend op de westmuur van de Sint-Laurentiuskapel - tot de helft van de breedte die zij op het „Rodeplan" inneemt.

Derhalve zijn wij geneigd te geloven dat het koor misschien nog langer moet geweest zijn. De funderingen van het romaans koorhoofd (O.L. Vrouwkapel) zouden dan nog iets meer Scheldewaarts zijn blijven bestaan. Altijd steunend op het „Rodeplan” kan de voorkerk ook dieper geweest zijn. Zoals hoger reeds betoogd zouden alleen ernstige opgravingen ons meer klaarheid kunnen verschaffen in dit probleem.

Een ander gewichtig document is het schilderij van een kerkinterieur dat bewaard wordt in het Bijlokemuseum te Gent (afb. 9). Volgens de traditie zou dit het interieur zijn van de Sint-Pieterskerk.

Genomen naar het noord-oosten ziet men dadelijk dat men hier staat voor een kerk met een vier traveeën diep koor met halfronde sluiting en kooromgang. Op de kooromgang noord, bemerkt men een door zuilen gescheiden aanbouw. Dit stemt o.i. overeen met het koor van het „Rodeplan" genomen ter hoogte van de St.-Denijskapel.

Onder de ramen van het koor loopt een triforium wat zou kunnen 
kloppen met de tekeningen van Arent van Wijnendaele.

De transept - even hoog als de middenbeuk - bezit eveneens een triforium en geen venster in de oostmuur. Het koor en het schip worden gescheiden door een dokzaal bestaande uit drie spitsbogig afgedekte doorgangen rustend op twee zuilen. Links en rechts zijn altaren aangebracht. Boven het dokzaal staat een kalvarieberg.

Van de benedenkerk zijn drie beuken afgebeeld die gescheiden worden door kruisvormige pijlers met in de hoeken ingewerkte posten, wat nagenoeg in overeenstemming is met het „Rodeplan".

De eerste afgebeelde travee van de zijbeuk vertoont een dubbele omgang. Hoewel dit in tegenspraak schijnt te zijn met hoger genoemd plan, mag toch niet uit het oog worden verloren dat de kans open blijft dat de noordzijdebeuk - die op dit plan heel wat breder werd getekend - kan opgedeeld zijn geweest in zijkapellen.

Vergeten wij ook niet dat bij de auteur van het „Rodeplan” zeker de bedoeling niet voorzat een uitgewerkte plattegrond van de kerk te brengen. In dit verband zij gewezen op het feit dat in de O.L. Vrouwkapel vier pijlers als steun fungeren, terwijl men uit de litteraire bronnen toch weet dat daar negen zuilen voorhanden waren ${ }^{69}$. Dit laat ons toe te veronderstellen dat er zich tussen de vier zware steunen, vier lichtere kunnen bevonden hebben en één in het midden.

\section{MONUMENTALE}

Niettegenstaande er tot op heden geen spectaculaire opgravingen plaatsvonden in de ondergrond, noch ten noorden, noch ten oosten van de barokkerk, werden toch enkele sporen teruggevonden van de voormalige abdijkerk.

De opgraving van 1932, onder de vierde travee-zuid van het huidig koor ${ }^{70}$ die in 1951 enigzins verruimd werd, legde een muurpand bloot van $3,00 \times 1,80 \mathrm{~m}$. bij een hoogte van $85 \mathrm{~cm}$. (afb. 10). Dit fragment bestaat uit Doornikse steen gemetseld in visgraat verband waarop een $3 \mathrm{~cm}$. dikke witte bepleistering werd aangebracht. Aan de voet bevindt zich de kerkvloer die samengesteld is uit een steenslag verharding van circa $7 \mathrm{~cm}$. dikte met aan de dagkant een okerrode slijtlaag variërend van $3 \mathrm{~mm}$. tot $1 \mathrm{~cm}$. dikte.

Deze bevloering - aangemaakt uit verbrijzelde gebakken aarde vermengd met kalk - ligt volledig vlak zonder sporen van een latere betegeling. In de karolingse en romaanse kerken waren dergelijke bevloeringen legio. Dit was o.m. het geval te Gent in de kerk van de vroegere St.-Baafsabdij en in de romaanse St.-Niklaaskerk ${ }^{71}$. Hieruit blijkt dat deze fragmenten misschien thuis horen tot de kerk van de 8ste of 9de eeuw die in 960 afgebroken werd.

(69) M. Deruelle, o.c., p. 63

(70) M. Deruelle, o.c., pp. 55-57.

(71) F. de Smidt, de kathedraal te Gent, Archeologische studie, Brussel, 1962, pp. $60-61$. 
Het peil van deze bevloering ligt $1,30 \mathrm{~m}$. onder dit van de huidige noordpand en op $3,85 \mathrm{~m}$. onder dit van het koor van de barokkerk.

$\mathrm{Bij}$ het uitvoeren van een sondering in de keldering onder de noordkooromgang van de barokkerk bleek dat de bevloering aangebracht werd op de geschapen grond. Deze zandlaag is zodanig kompakt dat er bij het graafwerk een houweel aan te pas moest komen.

Niet minder belangrijk was de vaststelling dat deze bevloering nagenoeg op hetzelfde peil ligt als deze die in 1932 voor het eerst aan het licht kwam (afb. 11). Op circa één meter boven de oude kerkvloer bemerkt men in de opvulling resten van een jongere muur of pijler gemetseld in regelmatig verband in Doornikse steen. Dit fragment zou kunnen opklim. men tot de kerk die na de brand van 985 door abt Wichard hersteld werd. Dit wijst uit dat de oudste kerk reeds zeer vroeg werd afgebroken.

Opsporingswerken in de loop van $1954^{72}$ uitgevoerd in de kloostergang legden een reeks oude grafkelders bloot (afb, 12). Deze ontdekt vlak onder de moerboog van de eerste en tweede travee ligt op circa $0,29 \mathrm{~m}$. onder de huidige bevloering. Fresco's die op de wanden voorkomen laten een datering toe in de 14 de eeuw (afb. 13).

In de zevende travee ligt de deksteen van de aldaar gevonden gotische grafkelder evenwel $46 \mathrm{~cm}$. onder de bevloering, terwijl deze van abt Amandus Hovelinck ( $t$ 1679) in de oostpandgang amper $30 \mathrm{~cm}$. onder de bevloering werd aangetroffen.

Over het algemeen ligt het peil van de 23 teruggevonden grafkelders dus op normale aanlegdiepte. In dit verband mag verwezen worden naar anologe gevallen in de St.-Baafsabdij ${ }^{73}$.

Wat meer is, gedurende de opgravingen van 1954 werden in de pand geen oude bevloeringen teruggevonden zodat men gerust mag stellen dat het peil van de romaanse kruisgang later gehandhaafd werd.

$\mathrm{Bij}$ het uitvoeren van hoger geciteerde opgravingen werden in de noordpand nog enkele andere belangrijke vaststellingen gedaan.

Over een grote lengte werd de romaanse fundering in Doornikse steen ontdekt van de noordermuur, samen met een nog aangewerkt voetstuk van een basis die zelf verdwenen is. Ook hier werd niets van een aanliggende bevloering teruggevonden.

De noordpandmuur - gebouwd in baksteen - moet in de gotische periode thuishoren. Bij het uitvoeren van de afbikkingswerken in 1951 werd aldaar tevens de oude toegang teruggevonden (afb. 14) tot de lichthof van de verdwenen kerk. Voorzien met kantblokken in kalkzandsteen werd deze toegang, bij het bouwen van de bredere en minder lange barokkerk, dichtgemuurd.

De verdieping van de noordkloostergang moet dateren van voor de beeldenstorm. Volgens het "Rodeplan" was er aan die kant kerkwaarts een grote lichthof. Deze hypothese wordt niet alleen gestaafd door het nog bestaand venster boven de oude toegangsboog (afb. 15) maar ook door al

(72) Stadsbestuur van Gent, Gebouwendienst - Bijzondere opdrachten, SintPietersabdij, Grafkelders, 1954.

(73) F. de Smidt, Opgravingen in de Sint-Baafsabdij te Gent, de abdijkerk, Gent, 1956, pp. 251-277. 
de toegemuurde vensters (afb. 16) die aan die kant op de verdieping in het muurvlak nog bestaan en die voorzien waren van zitbanken. Ook kwam in de laatste travee de tudorbogig overdekte poort (afb. 17) te voorschijn, die van uit de kloostergang toegang verschafte tot de zuidzijbeuk van de kerk.

Sporen van een korf- en segmentboog (afb. 18) bevinden zich nog steeds in het muurvlak van de tweede en de derde travee van de muur van de zuidkooromgang van de huidige kerk. In dit gedeelte, bestaande uit baksteenmetselwerk, bezitten de ramen geen omrandingen in natuursteen. Hun dagkanten werden met platte tegels uitgedikt. Even boven de genoemde bogen komt in het metselwerk een versnij voor dat $3 \mathrm{~cm}$. bereikt. Op het muurvlak is de aanzet van een lessenaardak nog waarneembaar. Dit kan dan de verbinding geweest zijn tussen de „dormter" en de bibliotheek die - volgens het „Rodeplan" - ingericht was boven de zuidzijbeuk van de vroegere kerk.

$\mathrm{Bij}$ het uitvoeren van bijkomende uitdiepingswerken van de keldering onder de zuidkooromgang van de barokkerk (afb. 19) werd tussen de funderingsvoeten - vlak vóór de muurpenetratie van 1932 - een graf gevonden, gemetseld in onregelmatige blokken Doornikse steen. Helemaal met zand gevuld werden hier geen resten van een skelet aangetroffen. Wij durven hier de vraag opperen of men hier niet stond voor de tombe van de in 995 overleden abt Adalwinus. Inderdaad, deze was gelegen ,intra parietes sacelli S. Benedicti" "74. Deze vindplaats klopt wel niet volledig met de door ons vooropgezette ligging van die kapel, maar is toch genoeg benaderend om tot nadenken te stemmen.

Nog voor een opmeting van deze interessante vondst kon worden gemaakt werd het graf door de stadsdiensten opgeruimd. Gelukkig werden toch enkele foto's genomen ( $\mathrm{afb}, 20-21$ ) zodat men de aanlegdiepte optisch op circa $50 \mathrm{~cm}$. onder de oude bevloering mag stellen.

Dat de drie steunberen van de huidige O.L. Vrouwkapel (afb. 22-23) zouden opklimmen tot de romaanse periode ${ }^{75}$ hebben wij aan de werkelijkheid willen toetsen door het uitvoeren van enkele sonderingen. Onder de bevloering van het lokaal - liggend onder de bergplaats van de barokkerk - palend aan de zuidmuur van de O.L. Vrouwkapel kwamen reeds op een diepte van circa $12 \mathrm{~cm}$., zij op 3,60 m. onder het peil van de in 1932 ontdekte rode bevloering van de voormalige kerk, enkele funderingen in Doornikse kalksteen te voorschijn die deel kunnen uitgemaakt hebben van het Karolingisch bedehuis (afb. 24).

Tot op peil - 1,65 m. onder de bevloering van kwestige bergplaats vertonen deze resten nog altijd het aspect van funderingsmetselwerk. Derhalve zouden wij durven stellen dat de krypte zich niet daaronder maar wel hoger bevonden heeft. De diepe breuk (afb. 24) in het metselwerk kan toe te schrijven zijn aan de drukking uitgeoefend door de baroktoren.

De controle van de drie steunberen en de onderste geleding van de O.L. Vrouwkapel wijst uit dat hier slopingsmateriaal van zeer ongelijk

(74) M. Deruelle, o.c., p. 170.

(75) M. Deruelle, o.c., p. 68. 
gehalte in laaghoogte werd gebruikt.

$\mathrm{Bij}$ het maken van een vijf meter diepe sleuf tussen deze steunberen werd hun aanlegdiepte niet bereikt. Ten overstaan van de lengteas van de barokkerk vertoont de centrale steunbeer een lichte afwijking naar het noorden toe. Hier mag worden angestipt dat, zoals blijkt uit de rekeningen deze kapel begonnen werd in 1628 en voltooid was in $1630^{76}$. De diepe bouwpunt aangelegd in 1628 werd naderhand volgestort met allerlei slopingsmateriaal. Sporen van blindnissen of iets dergelijks werden in de onderzochte muurvlakken niet aangetroffen, wat o.i. een bewijs te meer is dat deze constructie niet behoort tot het oorspronkelijk romaans gedeelte van de O.L. Vrouwkapel.

\section{SITUERING}

Zoals overal elders in West-Europa behoorde de voormalige Sint-Pieterskerk - met aan weerskanten van het hoofdaltaar het koorgestoelte - tot het meest essentiële gedeelte van het kloosterkompleks.

Als type-plan mag voor de oudste kerk van St.-Pieters gedacht worden aan de algemeen in zwang zijnde, vlak overzolderde pijlersbasiliek. Het is evenwel mogelijk dat het bedehuis gebouwd door Einhard, een centraal bouw zou geweest zijn, in de zin van de paltskapel te Aken.

$\mathrm{Bij}$ het overbrengen in 870 van de relieken van de $\mathrm{H}$. Amelberga uit Temse wordt gezegd dat deze werden bijgezet in het koor. De overbrenging van de relieken o.m. van de H. Wulfram in 945 kan in verband gestaan hebben met de werken die in 975 aan het koor werden uitgevoerd. In $979 \mathrm{kwam}$ de westbouw gereed. Opgetrokken op rechthoekige plattegrond kan het een $\log$ bouwwerk geweest zijn waaruit in het midden een toren oprees die geflankeerd werd door traptorentjes. Toegewijd aan de H.H. Petrus en Paulus zou deze westbouw kunnen gediend hebben en als koor, én als parochiekerk.

Aan weerskanten van dit koor kan een toegang bestaan hebben zoals o.m. te Maria-Làach (1156). Bij dit juweel van de Rijnlandse romaanse architectuur werd het atrium maar opgericht gedurende het eerste kwart van de 13 de eeuw tenzij dat - zoals bij de St.-Baafsabdijkerk te Gent (ca $1138),-$ in de as van de westbouw een breed portaal voorkwam. Indien zo dan lag het altaar van de tweede patroon op de verdieping. Hier mag o.i. ook verwezen worden naar het atrium van de St.-Donaaskerk te Brugge dat in 1086 tot begraagplaats werd ingewijd.

Deze atria - die de naam "paradisum" dragen - waren door portieken omringde open voorhoven. Boven deze galerij kwam soms een verdieping voor die vanuit de kerk door trappen bereikbaar was zoals te Centula (Saint Riquier - bij Abbeville). Een uitmuntend specimen daarvan is de zgn. Karolingse poort van Lorsch, die evenwel nooit met de omgevende galerij is verbonden geweest.

Wij denken tevens aan: Cluny II (981) - waar behalve het atrium ook

(76) R. van Driessche, Bouwgeschiedenis der barokke St-Pietersabdijkerk te Gent, in: Handelingen van het $6^{\circ}$ Congres voor Algemene Kunstgeschiedenis, Gent, 1942, pp. 67-90. 
een narthex bestond -; Saint-Philibert de Grandlieu te Tournus (1019); Saint-Benoit aan de Loire (11de eeuw); de Madeleine te Vezelay (1140) en Durham (1175). Toppunten van Anglo-Normandische architectuur werden deze bedehuizen voorafgegaan door een flinke en ruime voorbouw.

Een prachtig eksemplaar van westbouw is wel die van Corvey a/d Weser (873-885) die nauw verwant is aan deze van St.-Riquier.

In de Nederlanden komen dergelijke constructies reeds in de 9de eeuw veelvuldig voor o.m. St.-Gertrudis te Nijvel, St.-Bartholomeus en St.-Jacob te Luik, St.-Vincentius te Zinnik ${ }^{77}$.

Of het in de documenten van de 14 de-15de eeuw veelvuldig genoemd "paradijs" gelegen was in de westbouw, moet een open vraag blijven. Vermoedelijk werden én atrium én westbouw gesloopt in 1408 bij de afbraak van een groot gedeelte van de benedenkerk. Zoals hoger werd uiteengezet zijn er voorlopig geen afdoende bewijzen voorhanden die het bestaan van een atrium in de 12 de eeuw zouden bevestigen.

Wat aangaat de benamingen "Bavstorre" (1397) en "Boudinstorre" (1444) is het mogelijk dat dit louter een herinnering is aan de plaats waar zich eeuwen vroeger aan de westgevel of elders, trapkokers hadden bevonden ${ }^{78}$.

De verruimingswerken die in 1073 aan de St.-Pieterskerk gebeurden, grepen plaats aan het koor. Dit valt samen met de eerste vermelding in 1074 van de krypte. Het is niet uitgemaakt waar de in 1092 herstelde St.-Niklaaskapel zich bevonden heeft.

Een voorname faktor die de Pieterlingen zal bewogen hebben tot het doorvoeren van de in 1073 begonnen werken mag o.i. gezocht worden in de grote aanwas van relieken en de daarmee gepaard gaande verering die door de gelovige massa tot een ware kultus was opgevoerd. Aanvankelijk bevonden de relieken zich onder het hoofdaltaar in de krypte.

Pas voltooid in 1216 met de inwijding van de O.L. Vrouwkapel moeten de werken aan het koor zeer omvangrijk zijn geweest. Ook het koor van de abdijkerk van Lobbes a/d Samber werd op het einde van 11de eeuw verlengd. Gelijktijdig werd de oorspronkelijke corridor-krocht omgeschapen in een hallekrypte ${ }^{79}$.

Het klaverbladvormig koorhoofd van de St.-Pieterskerk vertoonde verwantschap met dit van de abdijkerk van St.-Martin-des-Champs (ca 1140) te Parijs, en met het koor van de Cisterciencerkerk te Vaucelles (1190-1220). In plaats van cirkelvormig te zijn bezat de Mariakapel

(77) M. Eschapasse, l'Architecture Benedictine en Europe, Paris, 1963, pp. 14-15, 25, 31-38, 46-47, 72, 96, 101, 111, 146, 162-163; F. de Smidt, Opgravingen in de St-Baafsabdij te Gent, Gent, 1956, pp. 31, 223; F. de Smidt, De Romaanse Kerkelijke Bouwkunst in West-Vlaanderen, Gent, 1940, p. 18; Kan. R. Lemaire, De Romaanse Kerkelijke Bouwkunst in de Nederlanden, Leuven, 1954, pp. 25, 31-33, 55-56; E. Hempel, Geschichte der Deutschen Baukunst, München, 1956, pp. 27, 33, 37, 44; Ph. Schmitz, Histoire de l'ordre de Saint Benoît, Maredsous, 1942, D.2, pp. 215-224, 226-228, 248.

(78) M. Deruelle, o.c., p. 83; d. 47, $36^{2}$.

(79) M. Eschapasse, o.c., pp. 16, 74; Kan. R. Lemaire, o.c., pp. 59-63; S. Leurs, Geschiedenis van de Vlaamse Kunst, Antwerpen, z.d., D.I. p. 113; S. Leurs, Geschiedenis der Bouwkunst in Vlaanderen, Antwerpen, 1946, p. 1. 
evenwel een polygonale sluiting bestaande uit de vier zijden van een regelmatige zevenhoek.

Verder leunde het ongewoon diep koor met deambulatorium aan bij dit van Notre-Dame te Jumièges (1037-1066) en bij deze van de grote Engelse kathedralen van na de verovering van dit land (Hastings 1066) door de Normandiërs. Zo o.m. de bedehuizen van Gloucester, Winchester, Norwick, Canterbury, Bury, St-Edmunds, Salisbury, Westminster, Exeter, Berverly en Lincoln. Bij de laatste vijf genoemde kerken is ook een tweede kruisbeuk voorhanden. Deze ordonnantie verscheen het eerst bij de verbouwing - op het einde van de 11 de eeuw - te Canterbury. Daarna gebeurde iets dergelijks te Cluny III (1100) en te St-Benoit aan de Loire.

Het inschakelen van de oosttransept te St-Pieters sluit dus aan bij hoger geciteerde bedehuizen die in hun grondplan de vorm van een Lorreinskruis vertonen. Ook moet het enige gelijkenis bezeten hebben met het koor van de St.-Niklaaskerk te Gent die, samen met de huidige kathedraal een van haar talrijke patronaatskerken is geweest.

De uitgestrekte domeinen die de Pieterlingen - sinds 918 - in Engeland verworven hadden, ook de goede betrekkingen die zij in de eerste helft van de 13 de eeuw met de bisschop van Rochester, Gilbert van Glanvel, onderhielden zouden een niet te onderschatten rol kunnen gespeeld hebben bij het concipiëren van het grondplan van de abdijkerk.

Daar het koor reeds in 1216 oostwaarts uitgebreid was, kan men terzelfdertijd ook de krypte aangepast hebben. Gezien de ligging op de helling Scheldewaarts zal zij, net als die van de St.-Janskerk (kathedraal), wel geen onderaardse konstructie geweest zijn ${ }^{80}$. De bekende tekeningen van A. van Wijnendaele volstaan echter niet om ons enig idee te vormen over de ordonnantie van deze krypte.

De tribune - een verdieping die in de beuk uitgeeft en bereikbaar is door trapkokers die de hoeken flankeren - is van de 11 de eeuw af een kenmerk van de benediktijnerkerken. Niet alleen boven de narthex maar zelfs in de kruisarmen waren ze voorhanden.

Men treft ze o.m. aan in de volgende kerken: St-Remi te Reims, Ely, St-Riquier, Werden a/d Ruhr, Limburg aan de Lahn, Notre-Dame te Jumières, Laon, koor van St.-Donaas te Brugge, St.-Vincentius te Zinnik, schip en transept van de kathedraal te Doornik ${ }^{81}$.

Het bestaan van tribunes in koor-en transept in de St.-Pieterskerk is bewezen door de rekeningen van 1397-1399. Zoals bij de O.L. Vrouwkerk te Roermond (1218) werden ze beëindigd door "leeshuusen" in de vorm van erkers ${ }^{82}$.

(80) E. Lefevre-Pontalis, Les plans des Eglises romanes Benedictines, in: Bull. Mon., Paris, 1912, p. 479; M. Eschapasse, o.c., pp. 35, 38-39, 48-49, 57, 101-108, 151; V. Fris, Histoire de Gand, Gent, 1930, p. 8; M. Deruelle, o.c., pp. 84-86; F. de Smidt, De Kathedraal te Gent, Brussel, 1962, pp. 37, 213-214.

(81) M. Eschapasse, o.c., pp. 48, 69, 74, 148, 151, 157; H. Busch en B. Lohse, l'Architecture en Europe, Le Roman, 1964, p. XVI; F. de Smidt, de Romaanse Ketkelijke Bouwkunst in West-Vlaanderen, Gent, 1940, p. 29; Kan. R. Lemaire, o.c., pp. $218,226$.

(82) S. Leurs, Geschiedenis van de Vlaamse Kunst, Antwerpen, z.d. D.I, p. 64. 
De opstand van het koor - met loopgang aan de bovenvensters van de hoge lichtbeuk - zoals men die kent door de tekeningen van Arent van Wijnendaele gaf eerder de indruk van een romaanse bouw in plaats van een vroeg gotische. Dergelijke dispositie knoopt trouwens aan bij de romaans-anglo-normandische bouwschool, alsook bij de 13 de eeuwse gotische kerken uit Burgondië, Champagne en de laat-romaanse uit de Rijnstreek.

Buitenloopgangen zijn in ons land o.m. voorhanden aan de O.L. Vrouwkerk te Pamele, St.-Niklaas te Gent; bovenvensters van de kathedraal te Doornik, O.L. Vrouw te Brugge, Damme, koor en kruisbeuk te Lissewege, St.-Bavo te Aardenburg.

Of het triforium bestaan heeft uit gelijke openingen gescheiden door zuiltjes, of door meer geprofileerde staanders en drielobbige bogen (beuk van St.-Maarten te Ieper, koor van O.L. Vrouwkerk en van St.-Salvator te Brugge), of in een minder komplekse vorm (beuken te Pamele en van O.L. Vrouw te Kortrijk), of uit een meer ontwikkelde type bestaande uit twee of meer lichtopeningen zoals in de kruisbeuk te Ieper en in het koor van St.-Baafs te Gent ${ }^{83}$, kan an de hand van de gekende tekeningen niet worden bewezen. Indien het schilderij uit het Bijloke-Museum inderdaad het interieur van de gesloopte St.-Pieterskerk zou voorstellen, zou men geneigd zijn voor het eerste systeem te opteren.

Zonder evenwel de grootse allure te bezitten van de frans-gotische portalen moet dit van St.-Pieters - zoals het voorkomt op het zegel van abt Fulcro - niet zonder verdienste zijn geweest.

Hoe de romaanse vieringstoren er mag uitgezien hebben is ook niet te achterhalen. Best mogelijk was het een lantaarntoren in de trant van die van de St.-Niklaaskerk of in de stijl van die van de St.-Jacobskerk, beide te Gent ${ }^{84}$.

Aan de hand van de tekeningen van Arent van Wijnendaele kan niet worden uitgemaakt of de onderste torengeleding nog het uitzicht bewaard had zoals die in 1398 door van der Leyen gepland werd. Het octogonaal gedeelte en de torenhelm kon dateren van 1499-1534. Evenals o.m. die van de kathedralen van Antwerpen, Mechelen en Gent, behoorde de vieringstoren van St.-Pieters tot de grote scheppingen van de Brabantse gothiek ${ }^{\mathbf{8 5}}$.

Gezien op de tekening van A. van Wijnendaele aan het koor geen steunberen voorkomen, zou men geneigd zijn te geloven dat ook in de St.-Pieterskerk oorspronkelijk geen gewelven voorzien waren. Deze ontbraken eveneens aan de O.L. Vrouwkerk te Oudenaarde-Pamele.

Uit de bouwgeschiedenis weet men echter dat het koor van St.-Pieters in 1407-1408 reeds met kruisgewelven overkluisd was. Dit laat ons toe te stellen dat deze gewelven aanvankelijk wel konden voorzien zijn geweest. Dit was zeker geen alleenstaand geval. Immers, aan de St.-Salvators-

(83) S. Leurs, o.c., D.I, pp. 113-125, 130-131.

(84) F. de Smidt, De restauratie van de Sint-Niklaastoren te Gent, Brussel, 1967, pp. 247-264; F. de Smidt, De Sint-Jacobskerk te Gent, Brussel, 1966, pp. $56-66$.

(85) M. Deruelle, o.c., p. 84. 
kerk te Brugge waren o.m. van meet af an gewelven voorzien die maar pas in de loop van de 17 de eeuw werden gebouwd ${ }^{86}$.

De meest voorkomende vorm van steun die het hoofdkenmerk zal worden van de nederlandse gothiek is, de al dan niet met schalken beklede zuil. Men treft ze o.m. aan in: St.-Maarten te Ieper, St.-Salvator te Brugge, O.L. Vrouw te Pamele, koor van St.-Baafs en beuk van St.-Niklaas te Gent ${ }^{87}$.

Bij het „Rodeplan" zijn in de beuk echter pijlers als steunen voorhanden. Daarentegen werden de steunen én van de viering, én van het koor, ruitvormig getekend wat wijst op een meer komplekse vorm.

Hieruit zou mogen afgeleid worden dat de romaanse middenbeuk voor een goed gedeelte bleef bestaan. Zoals gekend, werd in de loop van de 15 de eeuw de noordzijbeuk alleen maar verbreed. De in 1407-1408 uit Doornik aangevoerde zuilen zullen dan misschien de plaats ingenomen hebben van de gesloopte noord-buitenmuur van de zijbeuk.

Zo komt men voor het schip van de kerk tot een middenbeuk die ten noorden geflankeerd werd door een ontdubbelde zijbeuk. Dusdanig zou het bij het „Rodeplan" groot verschil in breedte tussen de noord- en de zuidzijbeuk van het schip kunnen uitgelegd worden. Meteen zou ook de traditie bevestigd worden die het schilderij bewaart in het Bijloke-Museum, bestempeld als het interieur van de verdwenen abdijkerk van St.-Pieters.

\section{BESLUIT}

In vergelijking met de vroegere St.-Janskerk te Gent, zijn wij geneigd te geloven dat de romaanse kerk zich voordeed als een driebeukige vlak overzolderde pijlersbasiliek met krypte, vieringstoren en westbouw.

Ekonomische faktoren hebben in de 13de en 14de eeuw de basis gelegd voor de Franse invloed, die - voornamelijk via Doornik - in Vlaanderen doordrong.

Aan de hand van het „Rodeplan' en de tekeningen van Arent van Wijnendaele zijn die bouwfasen betrekkelijk goed te volgen.

Sommige gedeelten van de middenbeuk van het schip, de aanliggende zuidzijbeuk en transept kunnen tot de kerk van 1073 behoord hebben. Het diepe koor met kooromgang, oosttransept, apsidiolen en klaverbladvormige O.L. Vrouwkapel, de met een buitenloopgang voorziene hoge lichtbeuk van het koor, komen in Benediktijnerkerken onder Engelse invloed meer voor. Dit gedeelte van het gebouw kan voltooid zijn geweest in 1216. De noordzijbeuk van het schip, de aangebouwde kapellen, de vieringstoren, de pseudo-kooromgang-zuid, waren gotische konstrukties.

Samen met de kerken van de St.-Baafsabdij, St.-Niklaas, St.-Jacobs, St.-Michiels en de kathedraal, behoorde de voormalige St.-Pietersabdijkerk tot één van de grote architectonische gewrochten waaraan het heerlijke Gent zo rijk is.

(86) S. Leurs, o.c., D.I, p. 140.

(87) S. Leurs, o.c., D.I, pp. 126-127. 


\section{BIJLAGEN}

\section{$-1-$}

\section{5,2 JANUARI (?). - KONTRAKT MET LOODDEKER JAN MOENRAERDE.}

Vorwaerde jeghen Janne Moeraerde den lootdeckere van ziren werke.

Eene zekere voerwaerde es besproke tusschen minen here van Sente Pieters bi Ghend an d'eene zide ende Janne Moeraerde tennenpotghietere ende loetdeckeren van Ghend an d'ander zide als dat de vors. Jan Moeraerde vors. minen here werke ende husen orbolie zijn sal also dickene als min vors. here begheren zal an sine kerke ende huuze die der toe behoeren elken dach met eenen cnape om 10 gr. ( $\left.f^{0} 74\right)$.

Rijksarchief Gent, Fonds van de Sint-Pietersabdij, I reeks, cart. 9. LAUREINS VAN DER LEYEN.

Dit es de voerwaerde die vernieut ende verclaert es tusschen minen heere van Sente Pieters bij Ghend an d'eene side ende Lauwereyse van der Leyen/temmerman/ an d'andere side als dat hij meester wercman sijn sal van der kerken vorseid.

Eerst dat waert dat men eenich groet werc gheluc torre ofte andere mindere of meenre werke gherochte in dachuren te doen makene/ dat hii daer af't last ende mate draghen sal ende moeten gheven den werclieden ende selve oec dand an slaen als hij mach stellinghe te makene allen werclieden die der kerken binnen ende buten werken sullen lappen boeten achter huusen binnen ende buten an de hove ende al anders dat een goed ghetrouwe meester van werke sculdich es te doene/ behouden dien dat waert so dat hij eeneghen officiers die hen selven regeren ende haar officien hare propere goed hebben op oec eeneghen singulen heeren in hare cameren diende of wrocht dat hij anders van der kerken werken ledich gaen soude dat hij dat doen mach ende dat sij hem dat betalen sullen... sonder minderinghe van sinen pricipalen pencioene. Ende hier over sal de vors. lauwereins hebben dagheliix sine coste in de herberghe ter sciltcnapen tafele als ic thuus/ te Sceldevelt/ te Saffelaer/ te Zwinaerde of t'Ottersam bem. Ende waert so dat ic te Safflaer/Zwinaerde of Ottersam ware ende hii thuus te werkene adde of oec dat ic verdre buten ware/ der hii mi niet volghen no mochte/ so sal de vors. Lauwereys voer elken 
dach hebben een vierdeel wiins en de 1 groet broet ende 2 gr. goeds ghelts ende voerd sal de vors. Lauwereys deelen in alle profite ende vervalle die der herberghen toecommen gheliic sciltcnapen. Ende als ic ne gheene cleedre in de herberghe ne gheve eenen froc in te werkene ende oec alle spaense ende curtelinghen die niet ne doghen in temmerwerke te legghene... Ende boven al dese sal de vors. Lauwereys hebben jaerlix in pensioene geliic dat hij gheadt heeft $6 \mathrm{lb}$. gr. cleens ghelt valent in sterken ghelde $4 \mathrm{lb}$. gr. Dit was vernieut/verclaert ende besproken tusschen mi ende Lauwereys vors. Janne den Clerc daer hij siinde den $26^{\mathrm{n}}$ dach van Oegste 1395. (f०92vo - 93).

Ibid., cart. 9.

1397, 1 OCTOBER - 1398, 30 SEPTEMBER. - REKENING VAN ONTVANGER WAUTER KINDS.

\section{Pensioen}

1- Laureinse van der Leyen/ meester Temmerman der kerken voern. 72 lb. tjaers. (fo $10^{\text {vo }}$ ).

2- Jan van Masmene steene bij den heere Laureinse voers. van $21 / 2$ dousinen scalen te doen bruneerne... 15 sc. (fo 11).

3- Meester Jan Heebins 3 note steenen/ stic 2 sc. commen 6 sc. (fo 17).

Ibid., I reeks, nr 1162.

1397, 2 OCTOBER - 1398, 5 OCTOBER. - REKENING VAN LAUREINS LANCGHEERAERDS.

1- Item meester Jacoppe van Straten ghelaesmaker van wercke dat hij ghelevert heeft... in datum/den $29^{\text {sten }}$ dach van Maerte $30 \mathrm{lb} .12 \mathrm{~d}$. (f० 10).

2- Item Janne den Backere de houtbreker in Stefaens strate bij meester Laureinse van der Leyen/ diversche stoffen... den $13^{\text {sten }}$ daghe in Laumaend $8 \mathrm{lb} .3$ sc. (fo 11).

3- Item Roeger van der Wostinen en van dat men hem tachter was/ als van den cruce up den turre/ dat hii verghulde... den $10^{\text {sten }}$ dach van Decembere $6 \mathrm{lb}$.

4- Item van al den ruwen matten in Onse Vrouwen capelle.

5- Item Janne van den Stappe, loetdecker van den turre te deckene/ de wanghen ende tot onder den turre de taflen te ghietene/ ende hem te doen dienene al up sinen cost... $36 \mathrm{lb}$. (f० 19v0 20). 
6- Item Gillise van den Damme mets/ den ghevel an den turre/ van metsene ende te doen dienene... den eersten dach van octobere $60 \mathrm{lb}$. $(f \circ 20)$.

7- Item bij onsen heere den Abt ghegheven in tasse Rasen van den Nokere ende Clays van Niemaghen al 't greys dat in den buedic lach 't greys dat up Bavstorre up de voute lach neder te werpene in den buedic ende alle de steene die in den buedic laghen te scheedene al dit vors. in der heeren kerchof te voume/ of daer men hem lieden segghen soude al omme $36 \mathrm{lb}$. ( $f^{\circ} 20 \mathrm{v}^{\circ}$ ).

8- Item bij onsen heere den Abdt Rasen van den Nokere ende Clays van Niemaghen/ghegheven in tasse thuutlaes dat stond in 't paradijs an de sente Andries capelle/ van brekene/ quareele scoene te makene/ de tichelen scoene te makene/ al 't greys te vorne datter af blijft in de nederinghe voer mijns heeren her Philips van Massemine was. Item dat sy ter selver stede voeren zullen al 't greys hout ende nieuwe dat leecht up onse vrouwen kerchof tusschen den portale ende der stichelen neffens den muere al om 6 noblen valent $21 \mathrm{lb} .12 \mathrm{sc}$. (f० $20 \mathrm{v}^{\circ}-21$ ). Somme van den taswerke also verre als ic betaelt hebbe 273 lb. 12 sc. (fo 21 ).

Ibid., I reeks, nr 2261.

1399 (n.s.), 9 MAART. - KONTRAKT MET MEESTER-STEENHOUWER JAN HEBBINS.

W.:

Vorwende jeghen meester Janne Hebbins van den ghevele van den coere.

Kenlic zij allen lieden dat Mechiel de Croec/ als machtich ghestelt van minen heere van Ste Pieters ende meester Jan Heebins zijn commen voer scepenen van der keure in Ghend/ kenden ende lijden alsulke voerwaerde als hier naer volghet van worde te woerde. Kenlic zij allen lieden dat eene zekere voerwaerde es ghemaect tusschen minen heere van StePeeters an eene zijde ende meester Jan Heebins an d'ander zijde als van te makene eenen ghevel upgaende onder den boghe van den choere/ daers al nu een ghedeel es beghonnen/purrende daer 't beghonnen es ende streckende ghesloten tote onder den ouden boghe/metgaders d'een leeshuuse/emmer dat inghetrocken alsoe 't besprec es. Voert den voerseiden ghevel ghestoffeert duere veinstergaten/beelgesteden/lijsten/voyen/ maelgen ende anders/ghelijc dat betrec up een perkament inhaudt rustende onder minen heere voernoemd/beworpen ende met eenen zeghele daer up gheplact bij meester Janne vorseit. Ende desen vorn. ghevel sal meester Jan vors. wel ende ghetruwelike maken ende leveren vuldaen binnen SteJansdaghe naestcommende over een jaer binnen ende buten van witten Brabantschen ordune ende tusschen ghevult met goeder stoffen. Ende al 
stoffeersel van den capiteele van der duere upwaert ende up d'upperste maelgekine/ al van steene van loets/ende om al dit vors. werc wel ende ghetrauwelike te doene ende te doen doene ende bij werclieden te leverne ghelijc dat boven gheseit es/ emmer behauden dien dat de ghevel up zijn zal ende besloten ' $t$ ' Sente Bamesse naest commende/ ende daer toe te leverne ale de steene/calc/zavel ende al andere stoffe diere toe besich werden sal/ ijzer/loet/haut ende stellinghe huutghedaen/sal de vors. meester Jan hebben $65 \mathrm{lb}$. gr. Dit was ghedaen den $9^{\text {n }}$ dach van Maerte in 't jaer ons Heeren/als men screef 1398 in 't scependom heere Jacop van der Pitten/Her Pieter Amelricx ende haren ghezellen.

Aldus staet in scepenbouc van den zelven jare fo 42 (fo 153).

Ibid., I reeks, cart. nr 9.

$-6-$

1399, 20 MEI. - KONTRAKT MET JAN VAN DER STICHELEN EN JAN HANNEMAN.

Voerwaerde ghemaect jeghen Janne van der Stichelen ende Janne Hanneman om de steenen van den lavoeren in den cloestere te leverne.

Den $20^{\text {n }}$ dach in Meye in 't jaer 1399 maecte mijn heere van Ste-Pieters bij Ghend eene voerwaerde jeghen Janne van der Stichelen ende Janne Hanneman/roketins van Eesseghem als/ dat zij minen vors. heere leveren sullen binnen sinen waterporte in sinen cloester... alle de steenen die noch ten daghe van heden in den cloester te bringhen sijn/behoerende ter cappe van den lavoire van den vors. cloester ghelijc dat ze mijn vors. heere up andren tijt jeghen hemlieden ghecocht heeft... Hier over waren meester

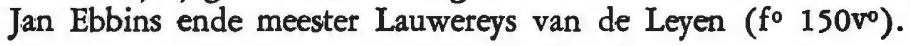

Ibid., I reeks, cart. nr 9.

1399, 20 MEI. - KONTRAKT MET BEELDSNIJDER JACOB DE BAERSE.

Voerwaerde ghemaect jeghen meester Jacob van den Baerse voer 20 zetelen in den coer.

Een zekere voerwaerde es ghemaect tusschen minenen heere van StePieters bij Ghend/ an d' een zijde/ ende meester Jacop van den Baerse beeldesnidere/ an d'ander zijde/ van 20 zetelen/ vormen of stoelen in 
den choer $t^{\prime}$ Sint Peeters vors./ alzo goed als diere nu staen of betere: te makene al nu/ stappans beghinnende in den cloester ende der hute niet sceedene vor dat vors. werc al vuldaen zal zijn in der manieren dat hier naer volghet.

Dat's te wetene: in elk zide 6 stoele in 't rechte ende 5 boven/ ende drie - benden keerende ghelijc zij ghecostumeerd zijn te keerne in alle andere kerken. Ende om dit vors. werc wel ende ghetruwelike ende in der manieren dat boven gheseit es te doene ende metten vloerwerke vuldaen ende vulstelt te leverne/ zal de vors. meester Jacop hebben boven dat hem mijn heere vors. alle de stoffen van haute ende van ijsere doen leveren zal/ den tijd dat hij se maken zal/ een vierendeel wijns ende een groet broed s' daeghs ende der boven van elken stoele of vormen drie noblen ende voerd ' $t$ verscoenen naer dat hire hem wel ende haestelike in quijdt van den prioer van Ste-Pieters voers. ende Pieteren ser Symoens. Dit was ghedaen den $20^{\text {n }}$ dach van Meye en 't jaer 1399/present den voers. prioer/ Pietren ser Symoens ende den heer Janne van Rode ( $f^{\circ} 152 v^{\circ} ; f^{\circ} 160$ ).

$$
\text { Ibid., I reeks, cartularium } \mathrm{nr} 9 .
$$

1400, 18 MEI. - KONTRAKT MET JACOP DE STOEVERE.

Voerwaerde ghemaect jeghen Jacop Stoevere de vaute onder de torre te stofferenne.

Den $18^{\text {n }}$ dach van Meye in 't jaer 1400 ward eene zekere voerwaerde ghemaect tusschen minen heere van Sente Pieters bij Ghend/ an d'eene zide/ ende Jacob de Stoevere/ an d' andere zijde/als dat Jacob vors. zal stofferen wel ende ghetruwelike de vaute/ die men seegt 't curce onder 't sconvent's torre/ in der manieren die hier naer volghet/ es te weten dat hij maken zal de viere groete loevere met goeden loveliken berghazure/ met finen vermeillioene/ met verghulden loedinen bloemen der in ghezait ende met goeden finen semente angheacht/ de boghen/ogiven en de al/ dat an 't vors. cruce ghebrecken mach/ even verre datter toebehoert ende te voeren was/ bij werclieden verstofferen zal ghelijc den hauden daer 't noch gheeel staet. Ende hiertoe moet hij leveren alle de stoffen ende andere zaken diere toe behoeren/stellinghe alleene hutghenomen. Ende/ om dit wel ende ghetruwelike bij den vors. Jacop den Stoevere ghedaen ende stoffe ghelevert te zine/heeft hem min vors. heere belooft $3 \mathrm{lb}$. gr. V1. munten. Hier waren present Andries van der Crayen/Jan van Roden/ moenke ende capellane/her Jan de Grave/ prochiepape van St-Jans lederne/ meester Jacob van den Baerse/meester Laureys van der Leyen (fo $169 \mathrm{v}^{\circ}$ ).

Ibid., I reeks, cart. nr 9; cfr. A. van Lokeren, Chartres et documents de l'Abbaye de Saint-Pierre au Mont Blandin à Gand, Gent, 1868-1871, D. II, pp. 150-151, nr 1480. 
1400, 8 SEPTEMBER. - KONTRAKT MET GILLIS VAN DEN DAMME.

Voerwaerde jeghen Gillis van den Damme/mets van den steghere $t$ ' sente Andries cappelle waert huten perdeze gaende.

Den $8^{\text {n }}$ dach van september $1400 /$ wart ghemaect eene zekere voerwerde tusschen minen heere van Ste-Pieters... ende Gillis van den Damme/ mets van Ghend/... als dat de vors. Gillis een dore maken zoude voer den steegher van Sente Andries capelle/ bezedt in beeden zijden met witten steenen ende also ommegaende al ' $t$ ronde/ over ander laghe met eenen slaghe ghehauwen/ hoeghe alzo de rechte muur/ eene doregat maken van coreele gheballouct/ der beziden met eenen steegher 5 trappen hoeghe neder te gane binnen den mure diere an staet/ de dore die nu in 't rechte van den mure staet vermetsen/ den muur in 't houcskin verscoyen/ den muur lancx bij den herden verstofferen... ( $\left.f^{\circ} 172 v^{\circ}\right)$.

Ibid., cart. nr 9.

1400, 1 OCTOBER - 1401, 1 OCTOBER, - UITTREKSELS UIT DE GENERALE REKENINGEN.

Generalen ontfanck

1- Item gherekent jeghen meester jacop den ghelaesmaeckkere van seekeren weerke/ghelijc ditt siine rekeninghe verclaert... $68 \mathrm{lb} .6 \mathrm{sc} .5 \mathrm{~d}$. par. ...( $\left(f^{\circ} 14\right)$.

2- Eerst ghecocht jeghen den langhen Backere bij meester Laureinse van der Leyen ende meester Jacop van den Baerse 350 voeten planken/ die verhuurbuert waren an den setellen in den choer ende up den torre van den convente met de versolderen... $12 \mathrm{lb} .12 \mathrm{sc}$. (fo 21).

3- Item 6000 carreele jeghen Fransoys Morale... dewelke verhuurbuert siin an de pilare/ bij miins heeren stoeve/ an de setellen in de vierscare an de veinsteren bij Sente Laureins autare an 't fondement/ an de setelle in de kerke... $12 \mathrm{lb}$. (fo $21 \mathrm{v}^{\circ}$ ).

4- Item van stoffen verhuurbuert up de huulaten boven Sente Pieters autaer of daeromtrent... $25 \mathrm{lb} .15 \mathrm{sc}$.

5- Item $11 / 2$ mudde calx verhuurbuert an 't fondement daer de setellen up staen in 't westhende... 27 sc. (fo 22 ).

6- Item 3 platte stile ende 6 sticken ghesaegts hauts dewelke verhuurbuert siin an de dueren die an 't lavoer staet ende an den inghane van den groeten choer/ costen 48 sc.

Dit sinn de taswerken binnen den vors. cloestere up dewelke men 
heeft betalet ter goede rekeninghen den persoenen alsoe sij hier naer volghen.

7- Eerst Gillis van den Damme... $60 \mathrm{lb} .16 \mathrm{sc}$.

8- Item meester Jan Hebbins... up taswerc van den ghevele in den groeten choer, alsoe de rekeninghe voer dese verclaert, alsoe men hem t'achter bleef, daer up betaelt ghelijc dat blijct bij letteren van quitancien ter goeden rekeninghen $104 \mathrm{lb} 12 \mathrm{sc}$. Blijct dat men hem t'achter blijft de deser rekeninghe van der voirs. eersten summe $11 \mathrm{lb}$. gr. qui valent in ponden parisis $132 \mathrm{lb}$. par.

9- Item Jacob den Stoevere/in vuller betalinghe van zeekeren taswerke van der vouten onder den turre te stofferen van scilderien/ghelijc dat de rekeninghe verclaert voer dese alsoe men hem doe t'achter bleef daer wulle betalinghe ghedaen ghelijc dat blijct bij letteren van quitantie midsghaders $12 \mathrm{lb}$. par. in de rekeninghe voer dese/comt/ $24 \mathrm{lb}$.

10- Item den selven/boven den vors. taswerke/ dat hij dede/ van der voirs. vouten wit te makene met conter vaerwen ten bevelene van onsen heeren den abt... $3 \mathrm{lb} .12 \mathrm{sc}$.

11- Item betaelt te goeder rekeninghe meester Danielle den Leenknecht, clocghietere ghelijc dat de voerwaerden verclaert van eener summe van ghelde van $10 \mathrm{lb}$. $18 \mathrm{sc}$. gr. daer up... betaelt... $7 \mathrm{lb}$. gr.

Ende es te weetene dat de vors. scellen waren gheghoten bij der hand van meester Danielle den Leenknecht en de Michiele siinen broeder ten bevelene ende te doen makene van onsen heere den abt/ her Gheraert Leuwaert in 't jaer 1401 in Oy maent. Ende elc van den vors. scellen wat elc wecht bij haerselven:

Eerst de miinste scelle van den sessen voirs. wecht 36 steenen $5 \mathrm{lb}$.

Item d'ander van onder upwaert wecht 64 steenen $1 \mathrm{lb}$.

Item de derde van onder upwaert wecht 84 steenen $1 \mathrm{lb}$.

Item de vierde van onder upwaert wecht 120 st. $1 \mathrm{lb}$.

Item de vijfste van onder upwaert wecht 164 st. $3 \mathrm{lb}$.

Item de seste van onder upwaert wecht 198 st. $3 \mathrm{lb}$.

Summa van den vors. scellen van haren ghewichten $568 \mathrm{lb}$. spisen.

12- Item meester Jacop van den Baerse betaelt in vuller betalinghen bij der hand van sinen cnapen/ die Jacop vors. hier sende dwerc te wuldoene/van den vors. setelen te stellen ende te makene alsoe de voerworde verclaert omme 60 nobelen/ waer af comt te betaelne ten bevelene van onsen heere den abt den vors. ontfanghere 30 nobelen qui valent in ponden par. $108 \mathrm{lb}$. par. waer af de vors. ontfangher betaelde den vors. Jacop in de rekeninghe voer dese $59 \mathrm{lb} .2$ sc. par. ende te desen rekeninghen ghelijc bij letteren van quitancien al betaelt $48 \mathrm{lb} .18 \mathrm{sc}$. (fo $23-24 \mathrm{v}^{\circ}$ ).

Dit siin de dachuure verwrocht in den vors. cloester... d'eerste weeke beghinnende den achsten dach inne Octobre:

13- Item Michiel Diederix/temmerman gewrocht met meester Laureinse van der Leyen an de deuren die hanghe, an den steegher van Sente Andries capelle... 11 sc. 
14- Item Jan vander Stappen/loetdecker ghewrocht an beede de crucehenden van der kerken als men de veinsteren maechte in den muer... ende dit was vergheeten in d'andere rekeninghe... 48 sc. (fo 25 ).

15- Item Jan de Prost van dat hij meester laureins hilp 't handwerc van den boghe in den buediic van der kerken... 12 sc. ( $\left.f^{\circ} 26\right)$.

16- (den $16^{\mathrm{n}}$ dach in sproekele 1401) Item... ten dueren bouf an 't lavoer ende ter duere van den groeten choere... 40 sc. (fo 28 ).

17- Item Jan Kesel ende sinen gheselle/saghers/diverse haute te saghene... ten beelfroede van den cleenen torre omme 6 scellen in te hanghene... ( 0 29).

18- Item Jan de Prost ende Gillis de Pratere 't vors. beelfroet van up 't hof van de kerke te draghene in den choer... $16 \mathrm{sc}$. (fo $31 \mathrm{v}^{\circ}$ ).

19- Item Jan de Prost... dbeelfroet te helpene rechtene up den torre... (12 april) (f० 32).

20- Item Jan Keesel ende sinnen ghezelle/saghers van kiepers/ te saghene die gehuurbuert waren an de huulate boven Sente Pieters autaer... mierdtsghaders spiersche berderen... an den hautinnen ghevel onder de Fiechghalen jegden den wint boven Sente Pieters autaer... ( $\left.f^{\circ} 34\right)$.

21- Item Gillis van den Damme omme 't fondament te makene onder de setelle in den choer in 't hende westwaert.. $30 \mathrm{sc}$. (fo $35 \mathrm{v}^{\circ}$ ).

22- Item Jacop van Leede te Roede ghevaeren omme diverse haute ten setellen bouf in den choer ten 4 waerven... $10 \mathrm{sc}$. (fo $37 \mathrm{v}^{\circ}$.

Ibid., I reeks, nr 2287.

1402, 17 FEBRUARI. - KONTRAKT MET LAUREINS VAN DER LEYEN BETREFFEND DE TOREN VAN DE KERK TE HULST.

Wij scepenen ende raet van der stede van Ghend... dat commen es voer ons in properen persoene Laureins van der Leyen de temmerman kende ende liide dat hii heeft belooft den turre van der kerken van Hulst te makene wel ende soffisantelike naer den inhouden van der voerwaerden hier naer volghende dats te wetene dat hii belooft te makene den turre vors. ghetrouwelik als goed man sonder eenighe fraude of maelengien also goet als eenich tor in Vlaederen staet sonderlinghe der toegenoemt den tor van Dixmude/ den tor van Deynse of van Beveren... so sijn borghen over hem ende elc over Laureins Spene: Martin Everart/Jan van der Stappen/Jan Metsaert/Jan Neyts/Gillis van den Damme ende elc up hemlieden en up al 't hare.

Actum 17 die Februarii anno $1401\left(f^{\circ} 32 v^{\circ}\right)$.

Stadsarchief te Gent, Jaarregister van de Keure, 1401-1402. 
1402, 1 OCTOBER - 1403, 1 OCTOBER. - UITTREKSELS UIT DE REKENINGEN.

Dit es... miins heeren van Sente Pieters bij Ghend rekeninghen...

1. Item meester Jacop van der Straten/den ghelaesmaker/ in vuller betalinghen betaelt van dies men hem $t^{\prime}$ achter... bleef... $24 \mathrm{lb}$. $6 \mathrm{sc}$. 6 d. (fo 14).

2- Item meester Jacop vors. ...van allen leveringhen/werken der vors. kerken toebehoerende... $5 \mathrm{lb} .19$ sc. $6 \mathrm{~d}$. ( $\left.\mathrm{f}^{\circ} 14 \mathrm{v}^{\circ}\right)$.

3- Item Jan Seghers-orloymeester/betaelt van sinen pensioene van stellene 48 sc. (fo 17).

4- Item ghecocht ende ontfaen jeghen Gillis Taerwaert ende Arend van den Sande 470 witte paveersteene... $58 \mathrm{lb} .15 \mathrm{sc}$.

Item van calke... verhuurbuert an 't pavement voer den groeten choerduere ende daer ontrent ghestoffeert ende an 't pavement bachten Sente Goewedaels autaer ende an 't pavement an Sente Denys' capelle ende elders... $20 \mathrm{lb} .16 \mathrm{sc} .6 \mathrm{~d}$. (fo 26).

5- Item van 25 trappen van wiitten steenen liggende up Sente Andries steegher... 5 lb. 12 sc. 6 d. (fo $26 \mathrm{v}^{\circ}$ ).

6- Item... in een seker taswerc ghegheven miins heeren waerderubbe te rumene die onder torreken staet bij der costerie...

7- Item meester Jan Hebbins betaelt in wuller betalinghen van der voerworden ende taswerke van den groeten ghevele in den choer... $36 \mathrm{lb} .8 \mathrm{sc}$. (fo $\left.27 \mathrm{v}^{\circ}\right)$.

8- Item Robbin de Brune an den vors. (choer) duere van snidene ghewrocht... 15 sc. $\left(f^{\circ} 28 \mathrm{v}^{\circ}\right)$.

9- Eerst Gillis van den Damme/Arend van den Poele ende Pieter Rebbe metse gewrocht an de cappelle daer Sente Kateline staet te verstofferene... $6 \mathrm{lb}$.

10- Item Robberecht de Brune an de choerduere ghewrocht van de snidene ende an de setelle te stellene 13 daghe... bij den rade van beede meesters van den werke (Laur. v.d. Leyen en Jan Hebbins) comt 6 lb. $10 \mathrm{sc}$. (fo $\left.28 \mathrm{v}^{\circ}\right)$.

11- Item Staes van der Scelt... an eene veinstere die in den ghevele van den choere staet... $42 \mathrm{sc} .8 \mathrm{~d}$.

12- Item Gillis de Buck ghevrocht an de duere in den choer ende up den torre met meester Laureinse van der Leyen... 36 sc. (fo 29).

13- D'eerste weeke beghinnende... den eersten dach in Novembre: eerst meester Laureins van der Leyen... gewrocht an de eengine die staen up den choer vouten an de raden elke 3 daghe.

14- Item van de Triniteit te rumene van den greuuse dat daer gheghadert was van hauden tijden... 18 sc.

15- Item Jacop van Eerleghem van den greuuse te wasschene ende te 
smeltene dat vonden was up de. Triniteit/daer af wel cam 48 steene loets ghepuergeert... $3 \mathrm{lb}$. $12 \mathrm{sc}$. (f० 33).

16- (juni) Eerst Gillis van den Damme van den selverine mannekine te verstellene in den pilaer vor onser vrouwen capelle/dwelk huute gheluuts was/ dat weder in te stellene... $6 \mathrm{sc}$. ( $\left.\mathrm{f}^{\circ} 36 \mathrm{v}^{\circ}\right)$.

Dit syn handghijften te kersavende ende hoefscheden binnen den jaere...

Rijksarchief Gent, Fonds van de Sint-Pietersabdij, I reeks, nr 2288.

1403-1404. - UITTREKSELS UIT DE REKENINGEN.

Dit es Andries van der Craye, monc ende upper ontfangher, rekeninghe.

1. Item gherekent ende betaelt jeghens meester Jacoppe van der Straten ghelaesmaeker van alle leveringhe ende weerken der vors. kerken toebehoerende/beghinnende in 't jaer XIIII ${ }^{c}$ ende vier waer af de summe comt ghelyc dat de rekeninghe verclaert/ende syn betaelt ghelyc dat blyct bij letteren van quitancien 43 sc. $6 \mathrm{~d}$. (f० $16-16 \mathrm{v}^{\circ}$ ).

Dit syn taswerke binnen den cloester.

2- Item van den boghe van den buediic van der kerken te doen vellene Gillis Musschen en de den Pratere omme eenen nobele comt $3 \mathrm{lb}$. 12 sc.

3- Eerst Jan van der Stappe vors. ghevracht (den 15 ste dach in Auste) an de cappe van den torre an de taffelen van den torre die up ghewayt waren van den groeten winden/die waren up eenen nacht in den wintere/ die weede te naghelene ende de taffele up haer werc te stellene 4 daghe met siinen cnape... comt 48 sc. (fo $35 v^{\circ}$ ).

4- Eerst Gillis van den Damme ende Coelin siin broeder ghevracht an de vors. muere (an de huulate van den doeremter) van den convente te verstofferene... $3 \mathrm{lb}$. (fo 37 ).

Ibid., I reeks, nr 2262.

1404, 1 OC'TOBER - 1405, 1 OCTOBER. - UITTREKSELS UIT DE REKENINGEN.

Dit's... miins heeren van Sente Pieters bij Ghend rekenenghe.

1- Item gherekent ende betaelt meester Jacop van der Straten ghelaesmakere van allen leveringhen ende weerke... $18 \mathrm{lb}$. $5 \mathrm{sc} .6 \mathrm{~d}$. $\left(\mathrm{f}^{\circ} 14 \mathrm{v}^{\circ}\right)$. 
2- Item Jan vander Stappen/loetdecker/an der torre ghevracht... $48 \mathrm{sc}$. (fo 29).

3- Item Coelin van der Damme ghevrocht an miins heeren cappelle de pilare te versettine die omme ghevallen waren ende in sticken ende an 't pravement in convent... 24 sc.

4- (december) Eerst meester Laureys van der Leyen up den vors. turre ghevrocht an de huusveinsteren... 32 sc. (fo 31).

5- Item Tiis van den Damme (steenhouwer) ghevracht an de presbiterie daer alle de legenden staen van der geboerten ende doet van Onser Vrouwen/die scoen te makene ende te wasschene met loeghen... comt $30 \mathrm{sc}$. $\left(\mathrm{f}^{\circ} 36 \mathrm{v}^{\circ}\right)$.

Ibid., I reeks, nr 2289.

1406, 25 FEBRUARI. - INVENTARIS VAN DE ORNAMENTEN.

Dit's overghegheve ende gheleverd bij den her Laureins prioer den her Janne den Zaghere tresorier den $25^{n}$ dach in Sporkele in 't jaer 1405 ghecopyert huut eenen billiette in pampier ghescreven dewelke onse heere d'abt mi overgaf sindert overghevert den her Pieters Boven (?) daer naer Willem van den Turre daer naer...

Dit sijn de reliquen in de hoeghe...

Eerst 't hellich cruce van ons heeren houte

Item 1 reliique van Sente Lievene daer men mede pleeght te seyene...

Dit zijn de fiertallen die ziin in de tresorie/ boven den groeten autaer.

Eerst de fiertele van Sente Wandregijse

...... Item eenen voet met datter toebehoert coperin verghult.

Dit zijn de juwele in de tresorie voer Sente Laureinse.

Eerst 't sacrement vat.

Item 't cleet dan men leyt up den stellinghe van den fiertels...

Dit's d'ornament huuter trianghelen

Eerst een blaeu cappe ghewrocht met diversen ymagien

Oudden Inventaris van der kercke Inventaris van den ornamenten

Ibid., II reeks, nr 406. 
1406, 1 OCTOBER - 1407, 30 SEPTEMBER. - UITTREKSELS UIT DE REKENINGEN.

Dit's Jan Myloth's rekeninghe van alle den coste van stoffe... taswerke/ dachueren... binnen den cloester...

1- Ghecocht jeghen Mahieu van Hollaing.../ jeghèn Michielle Poitevine... van Antoingen 175 blaus paviments... $11 \mathrm{lb} .11 \mathrm{sc}$.

Item noch van eenen zarcke die liggen zal in Sente Pieterscapelle $6 \mathrm{lb}$. $\left(\mathrm{f}^{\circ} 1 \mathrm{v}^{\circ}\right)$.

2- Item ghecocht jeghens gillise van den Damme 20 voete hecsteens ende verhuerbuert int kerckhof an de pilar/van elken voete 3 sc.... comt $3 \mathrm{lb}$.

3- Item ghecocht jeghens pieteren den puyt/ 12 weden linne om de stallige mede te makene int kerckhof alsmede wrachte an de pilar elke wede te 2 sc. comt 24 sc.

4- Item van de zeelen dien orboerde aan den turre.

... Item noch 6 wede linne die jan van den stappe verhuerbuerde an de stellage van den turre elke wede te $2 \mathrm{sc}$. comt $12 \mathrm{sc}$.

5- Item in de zelve weke (25n April) gillis de Prater breken den auden muur in den bodic te $4 \mathrm{sc}$. 's daegs comt... $8 \mathrm{sc}$. (fo 11).

6- Item de zelve weke (beghinnende $4^{\mathrm{n}}$ van Hoeymaendt) an de muere te breken in den buedic... ( $\left(^{\circ} 13\right)$.

7. De weke beghinnende up den $25^{\text {n }}$ dach van Hoeymaendt ghewrocht in 't kerchof ende an de zarcke wech te doene die in den buedic laghen (o.a. door Jan van der Weede) (fo 4).

8- De weke ghewrocht/up den $19^{\text {n }}$ September beghinnende an 't studoor boven Sente Benedictus capelle ( $\left.f^{\circ} 16 \mathrm{v}^{\circ}\right)$.

Ibid., I reeks, nr 2078.

1407, 1 OCTOBER - 1408, 30 April. - UITTREKSELS UIT DE REKENINGEN.

Dit's Jan Myloth's rekeninghe van allen den costen... van stoffen/... taswerke/dachueren... binnen den cloester ende buten up de hove...

1- Item van Mahieu van Hollaing/steenhauwer woenende te Antoingne... van 1 roede pilaers $(f \circ 1)$.

2- Ghecocht jeghen Arende van den Zande steenhauwer hute Brabant 600 witte paveersteene... comt $75 \mathrm{lb}$. 
3- Ende... jeghen Anthonise van Landois/ steenhauwer van Antoingne 80 blauwe paviments... comt $70 \mathrm{lb}$.

4- Item ghecocht jegen Gillise van den Damme 14 voete tafelments verhuerbuerdt in Sente Benedictus capelle ende an 't studoer van den dormpter... 42 sc. (fo 2).

5- Item Thys van den Damme/steenhauwer an de piscine die in de vors. (Sint-Benedictus) capelle leidt ( $\left.f^{\circ} 4\right)$.

6- Gillis van den Damme... in de kercke an de reprise voer Sente Kathelinen... 37 sc. 8 d. (fo $5 v^{\circ}$ ).

7- Item in de zelve weke (begin up den $12^{\text {sten }}$ dach van December) in 't quendt up de grave an sente Benedictus capelle ende de steene te doene in sente Kathelinen capelle.

8- Jan van der Stappen loeddeckere met sinen cnape an drie taffle loods die afgheweyt waren te verghietten ende te legghen ende de choer al omme te versien daers van noed was... $3 \mathrm{lb} .12 \mathrm{sc}$. $\left(\mathrm{f}^{\circ} 6 \mathrm{v}^{\circ}\right)$.

Ibid., I reeks, nr 1068.

1408, 12 JANUARI. - REKENING VAN DE NAAISTER VAN DE ABT.

Dit ziin diverse partien van werke die Celie mijns heeren van Zente Pieters bij Ghend naysterigghe in orbore van ziner kerken ghewracht heeft zinde alf Ougste in 't jaer 1407.

Eerst hare metgaders Ghizelbrechte mijns vors. heeren scepper te Brugghe ghetrocken om te coepene 't roede sindael te snidene jeghen 't blaeuwe dat miin vors. heere zelve bij hem adde om de gordinen van den groeten aultare $t$ ' Sente Pieters en tween vanen te makene ende de zide daer toebehoerende... $9 \mathrm{lb} .12 \mathrm{sc}$. par.

Item van den handghedade van den fringhen/linten ende coerden te maken ten vors. gordinen ende vanen $4 \mathrm{lb}$. par.

Item van 40 ellen wel goeds lijnwaeds daer af twee linine gordinen ten groeten aultaere ghemaect ziin ondersneden alf wit alf blaeu up ende neder ghestaect...

Item van 2 pilaren ende 2 inghelen witte linenen cleedene drien groeten witlinenen cleederen voer de fiertelen/ 8 witlinenen cleederen voer de bistorien an den rincmuer al binnen den coere it Sente Pieters te nayene boven dat Jan Ghaffelkin ontfangher in 't Gentsche d' linwaet betaeld ende in zine rekeninghe van den jare 1406 gherekent heeft 20 sc. par...

Somma van al den vors. parcheelen 48 lb. 12 sc. 6 d. par.

Gheeraerd bij den ghedoeghe Ons heeren Abdt van Zente Pieters bij Ghend onzen ontfangher in 't Ghendsche... dat ghij den vors. onzen scepper ende naystrigghen de vors. partien... betaeldt zonder ander bevel... 
Ghegheven in onzen cloester onder onzen secreten zeghel gheplact den $12^{\mathrm{n}}$ dach in Laumaend 1407.

W. Zadeleere

Ibid., I reeks, ligt in $n r 1182$, orig. pap. met zegel.

1408, 1 MEI - 1408, 24 DECEMBER. - UITTREKSELS UIT DE REKENINGEN.

Dits den staet van der officien van den upper ontfanghe in de Vlaemsche tonghe...

1- Item Roegeere van der Woestiinen/scilder/betaelt up eene zekre voerwarde van werke an Sente Cateliinen capelle ende beelde/ gheliic een ghecrifte van der vors. vorworden datten minn vors. heer af heeft verclaert. Ende voert van auden werke bii den vors. Roegeer ghewrocht ende ten vors. kerssavonde miinen vors. heere overbrocht bii ghescrifte. Ende beliep mids den $30 \mathrm{lb}$. par. die hi hebben soude van zinen vors. taswerke $41 \mathrm{lb} .3 \mathrm{sc}$. par.

2- Hier op vindinen bii 's heer Jan Milots rekeninghen ende oec bii der kennesse van Rogeer vors. datter der Jan Milot vors. betaelde ter goeder rekeninghen $31 \mathrm{lb}$.

3- Item soe betaelde he miin van den heer op den $28^{\text {sten }}$ dach van Auste in 't vors. jaer $6 \mathrm{lb}$. $\left(\mathrm{f}^{\circ} 20 \mathrm{v}^{\circ}\right)$.

4- Item Roegeere van der Woestinen/scilder/bii alsoe datte ziin taswerc an de cappelle ende ant beelde van Sente Catelinen vulwrocht adde $14 \mathrm{lb} .3 \mathrm{sc}$. (fo $31 \mathrm{v}^{\circ}$ ).

Dit ziin de coste die gheleyt ziin an de reparacien van der kerken... in den cloester...

5- Item meester Janne Heebins betaelt van eenen ghesnedenen steene/ de tabernacle van Sente Cateliinen in hare cappelle op te stellene meester Janne Heebins up den eersten dach van Juny in 't jaer XIIII' ende achte $4 \mathrm{lb} .7 \mathrm{sc}$.

6- Item Anthonise van Landaz/steenhaure/van Antoingne van 200 blaeus pavements. Elc hondert te 14 sc. 8 d. groeten betaelt op den $24^{\text {sten }}$ dach van Juny in 't vors. jaer... $17 \mathrm{lb} .12$ sc. par. (fo 38).

7- Item/den $10^{\text {sten }}$ dach van Septembre... betaelde miin vors. heer Anthonse van Landas van 12 voeten pilaers... $16 \mathrm{sc}$.

8- Item Gillis Tarvcoeren/steenhaure ute brabant van 6 veinstren van goeden witten steene... (fo $\left.38 \mathrm{v}^{\circ}\right)$.

9- ... betaelt/jegen meester Janne van Denremonde 12 voete rabats ... 3 lb. 12 sc. (fo 39).

10- ... Item Liefghetalle/temmerman/twee dueren makende ende hangghende ant poertael van der kerken... 45 sc. 
11- Item op den $28^{\text {sten }}$ dach van Auste in 't jaar XIIII' ende achte... Gillise van den Dame... eene stellinghe voer Sente Laureinse in ziine cappelle... $40 \mathrm{sc}$.

12- Item Lievine van Leede... van datti zekere steene van eenen piilare die van Doerneke ziin doen comen... 16 sc. (fo 41).

Ibid., I reeks, nr 2266; cfr. Ibid., I reeks, nr 2068.

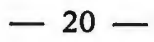

1408, 1 MEI - 1408, 24 DECEMBER - UITTREKSELS UIT DE REKENINGEN.

Dit ziin de coste die gheleyt ziin an de reparatie van der kerken van Sente Pieters bij Ghend/ in den cloester an de huisinghe ende buten up de hove...

1- Item Willeme van Toscanen/sloetmaker van tween sterken sloten d'een an miins heeren rekencamere ende d' ander an ziin torreken dat men heedt miins heeren studoer... $12 \mathrm{lb} .2 \mathrm{sc}$. ( $\left.\mathrm{f}^{\circ} 1\right)$.

2- Item Jacoppe van der Straten/ghelaesmaker... $10 \mathrm{lb}$. ( $\left(f^{\circ} 1 \mathrm{v}^{\circ}\right)$.

3- Item Mahieuwe van Hollain/steenhaure van Antoingen... 12 lb. 10 sc.

4- Item Arende van den Sande ende Gillis Tarvcoeren/ghesellen steenhauwers ute Braband... $100 \mathrm{lb}$. ( $\left.f^{\circ} 2\right)$.

5- Item Anthonise van Landas/steenhaure van Antoingne... $47 \mathrm{lb} .11 \mathrm{sc}$. $\left(f^{\circ} 2 v^{\circ}\right)$.

6- Item ghecocht... den $13^{n}$ Meye 1408 voirs. jeghen meester Janne van Dendermonde 12 voete rabats... ende eenen kerteelsteen... ghehuerbuert onder Sente Andries cappelle in de voute.. $5 \mathrm{lb} .15 \mathrm{sc}$.

7- Item meester Janne Heebins van eenen gesenedenen steene de tabernacle van Sente Carolinen in hare cappelle op te stellene... $4 \mathrm{lb} .7 \mathrm{sc}$.

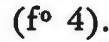

8- Item Gillis Tarvcoeren steenhaure ute Braband van sesse veinstren van goeden witten steene ghehauwen naer de scampelioene diere hem af overghegheven waren metten scoeten ende basen... omme de drie te stellene in Sente Amelberghen cappelle ende d'ander drie in't capitel... $40 \mathrm{lb}$. (fo $\left.4 \mathrm{v}^{\circ}\right)$.

Ibid., I reeks, nr 2068.

1408, 1 MEI - 1408, 24 DECEMBER. - UITTREKSEL UIT DE REKENINGEN.

Dit ziin de coste die gheleyt ziin an de reparatie van der kerken van Sente Pieters by Ghend/in den cloester an de huisinghe 
ende buten up de hove...

Dachueren betaelt diverschen lieden van ambachte ende hantwerkers.

1- Gillise van den Damme ende pieter Morale metse/metsende vriendach ende saterdach (de weke beghinnende Sondaegs $6^{\text {ste }}$ dach van Meye) an der Sente Andries cappelle... comt 30 sc. (f॰ 5 ).

2- Item Liefghetalle/temmerman/twee dueren makende an ' $t$ portael van der kerken ende hanghende in 5 daghe ende in miins heeren rekencamere.

1 dach... (de weke beghinnende sondaegs $17^{\text {ste }}$ dach van Juny)... comt 45 sc. $\left(f^{\circ} 6 v^{0}\right)$.

3- Item op den selven dach (18 $8^{\text {te }}$ Juny) betaelt Lievene van Lede ende Gillise van Musschenzeele van pavemente op te draghene... 3 sc.

4- Item up den $28^{\text {sten }}$ dach van Auste betaelt Gillise van den Damme van datti de stellinghe voer Sente Laureinse stelde de vaute verstoffeerde... $40 \mathrm{sc}$.

5- Item Lievene van Lede betaelt op den eersten dach van Septembre van datti zekere steenen van eenen pilare die van Doerneke ziin doen comen... 16 sc. (fo 7 ).

6- Item up den $20^{\text {ste }}$ dach van Decembre betaelt Liefghetalle voer de coer dueren versekerde... 16 sc. $\left(f^{\circ} 7 v^{\circ}\right)$.

Ibid., I reeks, nr 2068.

\section{2. - HERSTELLINGEN AAN DE BEUK VAN DE ABDIJKERK.}

Geradus Leeuwaert hic navim templi vulgo de bueck reparavit. Hic anno 1412 moritur et in sacello Divae Amelberghae sepilitus (fo 4).

Aliud de Gerardo Leeuwaert qui obiit anno 1412 jacet in tumba ex marmore nigro elevata ad pedem cum medio... aspera multa tulit/claustra pro more tuende atque refundavit navim templi reparando $f^{\circ} 9 \mathrm{v}^{\circ}$ ).

Universiteitsbibliotbeek Gent, bs. G. nr 11767.

1412, 22 APRIL - 1413, 23 JUNI. - UITTREKSELS UIT DE REKENINGEN.

Dit's Jans van den Bossche moenc van Sente Peeters bij Ghend rekeninghe.

1- Item meester Janne Bustiele/beelsnidere/up dwerc van der nieuwer tresorien betaelt den $28^{n}$ Meye... $12 \mathrm{lb}$. ( $\left.f^{\circ} 4 \mathrm{v}^{\circ}\right)$. 
2- Eerst 7 Meye betaelt meester Symoen van Assce rokier up leveringhen van sinen ghehouwen steenen... $100 \mathrm{lb}$.

3- Item Arende van den Sande ende Gillise Tarnhoefde... van steenen... $13 \mathrm{lb} .3 \mathrm{sc}$. ( $\left.\mathrm{f}^{\circ} 8\right)$.

4- Item ghegheven den $23^{n}$ dach van Aprille om de werclieden van den nieuwen werke enz. (fo $8 \mathrm{v}^{0}$ ).

5 Item Gillise van den Damme/mets/ vanden grave te metsene in Sente Amelberghe cappelle daer onse heere d'abt in leect/blikende bij eere lettren van quitancien $9 \mathrm{lb} .4 \mathrm{sc}$. (fo 9).

Rijksarchief Gent, Fonds van de Sint-Pietersabdij, I reeks, nr 2293.

1412, 19 JUNI - 1412, 23 OCTOBER. - UITTREKSELS UIT DE REKENINGEN.

Dit es dat Laureins Langheeraerdssone prioor van Sente Pieters bij Ghend ontfaen ende huutghegheven heeft.

1- Eerst betaelt Jacop van der Straten/ghelaesweerkere van houder scult... $12 \mathrm{lb}$. - Item... $15 \mathrm{lb} .16 \mathrm{sc} .8 \mathrm{~d}$.

2- Item ghegheven denselven Jacop vors. in minderinghen van sinen weerke dat hij gewrocht ende ghelevert heeft... $12 \mathrm{lb}$. (f० $\left.12 \mathrm{v}^{\circ}\right)$.

3- Item ghegheven Roegier van der Wostine die men heet de scildere up dweerc van Sente Amelberghen capelle... in daten $10^{\text {n }}$ dach van oymaent $12 \mathrm{lb}$.

Item ghegheven den selven Roegieren vors. up dweerc van Sente Amelberghen beelde ende capelle... den $27^{\mathrm{n}}$ dach van Oymaent $12 \mathrm{lb}$. (fo 13).

Item denselven Roegier... up dweerc van Sente Amelberghen tabernakele capelle ende datter toe behoert...

4- Item ghegheven Jan Bulteel/beilliesnidere up de nieuwe tresorie die staen sal up de prespeterie/in midneringhen... den $20^{\text {n }}$ dach van Oymaendt $12 \mathrm{lb}$. (fo $\left.13 \mathrm{v}^{\circ}\right)$.

Item ghegheven denselven Jan vors. in minderinghen... 28 Ougst $12 \mathrm{lb}$.

Item ghegheven densleven Jan vors. den 12 september $12 \mathrm{lb}$.

5- Item ghegheven denselven Jan vors. up de setels/vormen ende datter toebehoert/staende in den groeten coer van houder scult in minderinghen... 24n September 24 lb. 5fo 14).

6- Item ghegheven de weduwe meester Jan Ebbins van tween maenden van pencioene dat men meester Janne $t$ ' achter bleef... bij lettren van quitancen in daten den $30^{\mathrm{n}}$ dach van Julio $4 \mathrm{lb}$. ( $\mathrm{f}^{\circ} 15 \mathrm{v}^{\circ}$ ).

7- Item betaelt Symoen ende Vrancken van Assche/ghebroederen/roketiers in minderinghen... $100 \mathrm{lb}$.

Ibid, I reeks, nr 2294. 
1426, 20 DECEMBER - 1431, 25 DECEMBER. - UITTREKSELS UIT DE REKENINGEN.

Dit es Jans Haesbijts/moenc ende upperontfanghere van Sente Pieters clooster bij Ghend rekeninghe...

Dit is diversche stoffne ute Brabant ter kerken

1- Eerst van Arende van den Zande... orduun

Item van meester Heinric van Bautsvoorde... pylare ( $\left.f^{\circ} 10 \mathrm{v}^{\circ}\right)$.

2- Item 2 antcnapen omme 't werc in den choor alst ghevallen was $t$ ' helpen rechtene elk 3 daghe... 24 sc. ( fo 14).

3- Dit's diverce stoffene verbesicht in't paradijs ende nieuwe camere... (fo 24).

Ibid., I reeks, nr 146.

1430, 25 DECEMBER - 1431, 25 DECEMBER. - UITTREKSELS UIT DE REKENINGEN.

Dit es Jans Haesbijts... rekeninghe van diverschen goeden der vors. kerken toebehoerende.

\section{Calcman}

1- Gherekent met Janne den rike van calke ghelevert zindert kerssavont in 't jaer XIIII' ende XXX.

2- Eerst up heer Jans van Munte camer/ende up thulaet vor den choer 24 mudde ende onder de galerie/ Item 62 mudden calx t' scapelaens camer... (fo 11$)$.

Zavelman

3- ... van zavele mits capellaens camer/beloepen $120 \mathrm{karren} /$ ende 20 karren van heer Jans van Munte camer/ ende onder de galerie... (fo $11 v^{\circ}$ ).

4- Eerst Daniel van der Meersch/omme 't cremeel te weerne dat viel op St Pauwels avond/ ende op den torre te zine 1 dach 8 sc. par. (fo $\left.19 \mathrm{v}^{\circ}\right)$.

Ibid., I reeks, nr 1199. 
1430, 25 DECEMBER - 1431, 25 DECEMBER. - UITTREKSELS UIT DE REKENINGEN.

Dit es Jans Haesbijts... rekeninghe van diverschen goeden der vors. kerken toebehoerende.

1- Gherekent metten ghlaesmaker... van diverschen werken $53 \mathrm{lb} .5 \mathrm{sc}$. 4 d. par. (fo $\left.11 \mathrm{v}^{\circ}\right)$.

2- Item ontfaen binnen den zomer 1431 mits capellecamere 61.000 correele.

3- Item ghehaelt te Heinricx svos binnen den vors. jare eerst 1 zulle in Ste Janscapelle/ 5 voeten lanc... 11 salijtsteene... 11 voeten rabats Item ontfaen van Arende van den Zande... 20 voete orduns... 115 voeten dobbel trappen... 72 voeten cleener trappen... 69 voeten hecsteens.

Item ontfaen van Jan Trappaent van Bruesele $42 / 3$ ragemente van 3 ogive... item 12 voeten ogive $196 \mathrm{lb}$. 16 sc. par. (fo 13 ).

4- Item de veinstren up den nieuwen reftere te stoppene met cleeme $5 \mathrm{lb} .8$ sc. par. ...

5- Item den muer vor den vischreftere te brekene $4 \mathrm{lb} .16 \mathrm{sc}$.

Item den steene te rumene ende in den buedic te draghene... (fo 14).

Diversche dachueren...

6- Eerst Gillis van den Damme... in de haude tresorie... (fo 19).

7- Eerst Daniele van der Mersch omme 't huulaet te vermakene ( $f^{\circ} 20$ ).

8- Item Hannekine van den Damme 2 daghe te hauwene voer de archa $\left(f^{\circ} 20 v^{0}\right)$.

9. Item Arend van den Vivere up den torre... (fo 22 ).

10- Eerst Lauwereins van der Haghen... up den torre ende up de tremie van Sente Amalberghen... (fo $\left.22 \mathrm{v}^{\circ}\right)$.

11- Item den loetdecker... noch up de zuutcapelle... ende op onser Vrouwen capelle.

12- Item 2 metsen achter Onser Vrauwen capelle... (fo $26 \mathrm{v}^{\circ}$ ).

13- Eerst 2 metse omme de pipe van Jericho te hooghene... (f० $\left.27 \mathrm{v}^{\circ}\right)$.

14- Item den loetdecker boven der poorten van den paradijse in den buedic 4 daghe ende 1 an den bac in 't lavoir... 50 sc. par. ( $f^{\circ} 28$ ).

15- Item 2 temmerliede an Amalberghen te verhanghene/ elken $21 / 2$ daghe... 53 sc. 4 d. par. (fo $28 v^{\circ}$ ).

16- Eerst Arend van den Vivere in den buedic an 't lavoir ende an de pipe in't vrijthof... 7 sc. 4 d. par. (fo $\left.31 \mathrm{v}^{\circ}\right)$.

Ibid., I reeks, nr 1199. 
1431, 1 SEPTEMBER - 1432, 1 SEPTEMBER. - PENSIOEN VAN LAUREINS VAN DER LEYEN.

Dit is Triestrams van Hembise... rekeninghe:

Item Laureinse van der Leyen/temmerman/ sijn pensioen van 1 jaer dat hem viel te Sente Jansmesse 1432... $24 \mathrm{lb}$.

Ibid., I reeks, Varia, nr 146.

1433, 22 MAART - 1433, 25 DECEMBER. - UITTREKSELS UIT DE REKENINGEN.

Dit's Jan Haesbijts/moenc ende capellaen mijns heeren van Sente Pieters rekeninghe.

1- Item eenen caneuncx clerc die hu up den torre leede... 19 sc. p.

2- Item betaelt Heinric de Vos tafelment verbezecht voor Sente Andries capelle 4 lb. 12 sc. 6 d. par. (fo 18).

3- Item betaelt Pieter de Rudder boven de $9 \mathrm{lb}$. par. van den prioor hem ghegheven in vuller betalinghen van den trappen voor Sente Andries capelle verbezecht/van 21 trappen coste elke trappe 23 sc. par. comt surpluus dat ic betaelt hebbe $14 \mathrm{lb}$. 3 sc. par.

4- Item van den voors. steegher te maken Gillis van den Damme/ $61 / 2$ daghe... $8 \mathrm{lb}$. $12 \mathrm{sc}$. par.

5- Item den selven Gillis an 1 cleenen steegher 3 daghe... 45 sc. par. (fo $\left.18 \mathrm{v}^{0}\right)$.

Ibid., I reeks, rekeningen, nr 866.

$-30-$

1433, 1 SEPTEMBER - 1434, 1 SEPTEMBER. - UITTREKSEL UIT DE REKENINGEN.

Dit es Triestrams van Hembise... rekeninghe.

Item Laureinse van der 'Haghe/temmerman sijn pensioen... $24 \mathrm{lb}$.

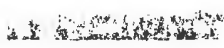

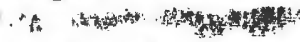
Ibid., I reeks, Varia, nr 146. 


\section{$-31-$}

1434, 25 DECEMBER - 1435, 25 DECEMBER. - UITTREKSELS UIT DE REKENINGEN.

Dit's Jan Haesbijts... rekeninghe... metten resten van den Ougste 1433 ende daer te vooren...

1- Eerst een zulle van 3 voeten in den nieuwen muer an't portael coste 6 sc. par. (fo $\left.10 \mathrm{v}^{\circ}\right)$.

2- Item besteedt an Gillis van den Damme den muer an 't portael up Onser Vrauwen keerchof jeghen de costerie die omme ghevallen was/ weder te makene... $23 \mathrm{lb}$. par.

Ibid., I reeks, nr 2299.

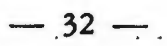

1435, 24 DECEMBER - 1436, 24 JUNI. - UITTREKSELS UIT DE REKENINGEN.

Dit's Jans Haesbijts/opperontfangher/rekeninghe.

1- Item Arende van den Vivere... up den nieuwen spiker an 1 gote/ ende up de cupe van den torre... 29 sc. 4 deniers par.

2- Eerst een ticheldecker up thulaet voor den choor te stoppene... $16 \mathrm{sc}$. par. $\left(f^{\circ} 9 \mathrm{v}^{\circ}\right)$.

3- Item de selve ticheldeckers up thulaet van der pareer camere $16 \mathrm{sc}$. 8 d. par. (fo 10).

Ibid., I reeks, nr 2269.

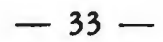

1436, 24 JUNI - 1436, 25 DECEMBER. - UITTREKSELS UIT DE REKENINGEN.

Dit's Jasn Haesbijts rekeninghe...

1- Eerst Gillis van den Damme... omme eenen sluutsteen te versiene boven den cleenen autare in den choor... 30 sc. par. (fo 10).

2- Item 2 temmerlieden omme Amalbeerghen te verhanghene mits dat 't hooft latste... Ib. 4 sc. par. (fo 11).

Ibid., I reeks, nr 2300. 
1436, 25 DECEMBER - 1437, 25 DECEMBER. - UITTREKSEL UIT DE REKENINGEN.

Dit's Jan Haesbijts moencs ende capellaen

mijns heeren rekeninghe.

Item betaelt bij minen heere van Ste Baefs... omme te werme de barbecane die men ghemaect wilde hebben van beeden kerken... 23 sc. par. (fo $18 \mathrm{v}^{\circ}$, cfr. fo $21 \mathrm{v}^{\circ}$ ).

Ibid., I reeks, nr 867.

1444, 16 APRIL - 1444, 25 DECEMBER, - UITTREKSELS UIT DE REKENINGEN.

Dit's 't gheene dat ic Willem van den Torre prioor van Sente Pietersclooster bij Ghend bevaen ende ghedaen hebbe naer de doot van den abdt Jan Haesbijt van den generalen ontfanghe beghinnende den 1 dach in April in 't jaer 1443 voor Paesschen duerende tot Kersmisse 1444.

$1^{\mathrm{e}}$ Rekening

Diverssche pensionaresse

1- Meester Robbrecht van Brune... $3 \mathrm{lb}$. par. (fo $5 \mathrm{v}^{\circ}$ ).

Diverssche stofven

2- Item betaelt 60.000 coereelen die d'abt Jan cochte...

Item betaelt 10.000 bleecker coereelen die d'abt Jan cochte...

Item betaelt op de 40.000 tichelen die d'abt Jan cochte... $48 \mathrm{lb}$. par.

Diverssche taswerken

3- Eerst besteed bij d'abt Jan an Heinderic den scaelgedecker de Noortcappelle te deckene... ende waren 21 roeden mitds den dobbele werke ende de turrekinne van den windelsteene comt 76 lb. 12 sc. par. $\left(f \circ 7 v^{\circ}\right)$.

4- Item besteed bij Laureys den temmerman an Joes van Sol scildere de huesse ende 't wederhane van den turrekinne metten beckinnen te verguldene ende de tremie van Sente Amelberghen te scildene 11 lb. 8 sc. par.

5- Item van den voors. beckinnen ende huesse te makene 8 lb. 2 sc. p.

Ibid., I reeks, nr 2069. 
1444, 15 NOVEMBER - 1445, 24 JUNI. - UITTREKSELS UIT DE REKENINGEN.

Dit's Lievins van Waes... rekeninghe.

1- Eerst betaelt Lauwereins Dullarde/temmerman van den 3 clocken te verhofdene ende te verhanghene/ es te weten Maria/Godewale ende Bertolve de somme van $84 \mathrm{lb}$. par. (fo 20).

2- Eerst om de stellinghe van den veinstere an Boudins torre 2 antcnapen/ 4 daghe elc... comt 40 sc. $\left(f^{\circ} 24 v^{\circ}\right)$.

Ibid., I reeks, nr 2301.

\section{$-37-$}

15' EEUW (ca 1444?). - BESCHRIJVING VAN HET MATERIAAL GEBRUIKT TOT OPBOUW VAN DE NIEUWE KAPELLEN BEZUIDEN DE TOREN.

Dit naervolghende es de ordinanchie van der nieuwer capellen an de zuutzijde van den turre van der nieuwer kerken van Sente Pieters bij Ghend alzoot hier naer volghende verclaert staet.

In it eerste twee zijlatten elc 30 voeten lanc...

Item eenen balke 39 voeten lanc...

Item twee platte stijlen elk 7 voeten lanc...

Item corbeelen elc 6 voeten lanc...

Item twee strijchouten d'een 32 voeten lanc ende d'ander 39 voeten lanc...

$$
\text { Ibid., II reeks, nr } 406 .
$$

Nota: Dit document is zeer breedvoerig en op de rugzijde komt de volgende tekst voor „raeckende Aude kercke". In het inventaris werd bijgeschreven dat het hier zou gaan over de parochiekerk van O.L. Vrouw op Sint-Pieters.

1449, 1 SEPTEMBER - 1450, 1 SEPTEMBER. - UITTREKSEL UIT DE REKENINGEN.

Dit es Godewaels van der Haghen ontfangher van den pachten in 't Ghendsche... rekeninghe. 
Item betaelt Lieven Ysenbarde van dat hij de scellen oversach in den cleenen torre een jaer lanc 31 sc. par.

Ibid., I reeks, Varia, nr 146.

1469, AUGUSTUS. - UITTREKSELS UIT DE REKENINGEN.

Rekeninghe benedictus Vutenhove religieux ende pitanchier ter causen van der pitanchie van den jare ende Augste 69.

1- Jacoppe goethals metsere die ten laste van der voorseider pitanchie heeft ghemets an de kerke van den voorseide cloostere ter ordonantie van mine voors. heere de spacie van 2 semi daghen in maarte/ item 20 semi daghen in de April/ item 22 daghen inde mey ende 13 daghen in de Wedemaent comt 58 daghen es beth. 10 sc. par. daghs.

2- Jacop de roevere cnape van den voorseiden metes die hem ghedient heeft ende ghewrocht in de voorseide kercke ten laste van den voors. pitancier ter ordinantien van mine voors. heere de spatie van 24 daghen in maerte/ item 20 semi daghen in de april/ item 22 daghe inden mey ende 13 in de Wedemaent es betaelt 5 sc. par. daghs.

$$
\text { Ibid., I reeks, nr } 1726 .
$$

\section{6, 5 JANUARI. - UITTREKSEL UIT DE REKENINGEN.}

Ontfanc ende huutghevene van der aelmoesen van den jare 75 Extraordinaires

5 januari minen heere van Sente Pieters te hulpen ter reparatie van den coere dien nootzakelijcke gheolpen zijn moeste etc... den weerclieden.... 143 lb. par.

Ibid., I reeks, Varia, nr 273.

1479, 24 DECEMBER - 1480, 24 DECEMBER. - UITTREKSELS UIT DE REKENINGEN.

Rekeninghe Claeis Heindricx... ter causen van zeker ende diversschen wercken ende reparatien...

Eerst d'huutgheven ter causen van der metselrien. 
1- De voors. Joes (Tiebaut) die den achtevsten dach van laumaent ende den eersten dach van sporcle ghestelt heeft op de tryniteit op de noortzijde... 8 sc. par.

2- De zelve Joes die... de vouten up de noortzijde van der Triniteyt beghonnen heeft af te slane... $8 \mathrm{sc}$. par.

3- Item heindric Moraen ende Joorys de Dobbelare metsers/ die in de eerste weke van Maerte hebben ghewrocht an de voute van de triniteyt up de noortzijde... comt 't samen hier bethaelt.. $3 \mathrm{lb} .5$ sc. par.

4- De zelve Heindric ende Jorijs (metselaars) die hebben beghonnen den $13^{n}$ dach in Marte an de voute van de Triniteyt $\left(f^{\circ} 1 v^{\circ}\right)$.

5- Item Joos tiebaert van eenen halven daghe dat hij 't greys van de triniteit gheweert heeft... 3 sc. par. (fo 2).

6- Heindric Morael ende Joris de Dobbelare die ghewrocht hebben de tweeste weke van hoymaent/beghinnende den $11^{\text {n }}$ dach... omme de voute te wittene... hier Bethaelt $4 \mathrm{lb} .5$ sc. 10 par. (fo 3 ).

7- De voors. Arend (Charlet) van $11 / 2$ dach ghewrocht an Onser Vrauwen aultaer in de cappelle achter den hooghen aultare... $12 \mathrm{sc}$. par.

8- Item Pieter Bulteel van $1 \frac{1}{2}$ daghe ghewrocht in de zelve capelle ten voorn. aultare... $12 \mathrm{sc}$. par. (fo $8 \mathrm{v}^{\circ}$ ).

9- Item Willem de Jagher/lootghieter/ die ghewrocht heeft up den nyeuwen buec ( $f \circ 11$ ).

10- Item meester Willem de glaesmaker van dat hij een paert in de ghelasen veynstre van Sente Niclaux capelle vermaect heeft dat metten winde uute ende in sticken ghevallen was... 24 sc. par. (fo 12).

$$
\text { Ibid., I reeks, nr } 2071 .
$$

1480, 24 DECEMBER - 1481, 24 DECEMBER. - UITTREKSELS UIT DE REKENINGEN.

Rekeninghe Jans van Cuelne/religieux ende aelmoesenier van St-Pieters clooster... van zekeren diverschen weercken ende reparacien.

D'huutgheven... eerst angaende der stoffen van der metselrien.

1- Eerst Pieter Scaelkin alias van Lede steenhaudere heeft ghenomen te leverne alle de ogive steenen die men verweercken zal in de vauteringhe van der nieuwer kerken... $55 \mathrm{lb} .12 \mathrm{sc}$. par.

2. Item de selve heeft noch ghelevert vijf slootsteene omme de vauteringhe van der selve nieuwer kerken welke costen $t^{\prime}$ samen $48 \mathrm{lb}$. par.

3- Item $28^{n}$ Novembris was ghevoorwaerdt bij mijnen heere van Sent Pieters an den voorn. Pieter Scaelkin die steenen die behooren zullen an den windelsteen/commende van Gruuninghe in de nieukerke... 56 lb. 2 sc. par. (fo 2).

4- Item de zelve pieter heeft ghenomen te leverne de pilaersteenen die 
behooven zullen buuten ande nieukerke daer de balken duere gaen ende de anckers up sluuten... $36 \mathrm{lb}$. 9 sc. par.

5- Item de selve heeft ghelevert 3 ogiven reprijsen inde ragemente.

6- Item de selve heeft noch ghelevert een vuerme in mijns heeren nieuwe zale... $6 \mathrm{lb}$. par. $\left(f \circ 2 \mathrm{v}^{\circ}\right)$.

7- Item Joos ende Pieter voorn. hebben ghestelt de stellinghe buuten den nieuwer kerken ende de gaten ghebroken daer de yserin balken duer den muer gaen ende omme de pilaers up te metsene... $31 \mathrm{lb}$. par.

8- Item Joos ende Pieter voors. hebben ghestelt de stellinghe omme te vautene in de nieukerke... $3 \mathrm{lb}$. par.

9. Item de voors. Joos ende Pietere hebben noch ghestelt ende de ogiven up ghewonden... $3 \mathrm{lb}$. par. (fo 4).

10- Item ghevoorwaerde... omme 't greys ende de steenen te voerne.../ dat commen soude van den poortale dat stont jeghen Sent Andries capelle... $\left(f^{\circ} 4 v^{\circ}\right)$.

11- Item Heindric Morael heeft ghemetst in mijns heeren lochtinc behinnende $17^{\text {en }} \mathrm{Meye} / \ldots 3 \mathrm{sc}$. daghen/mids dat hij Pieteren van Lede de berderen sneet van den pilaren buten der kerken ten prijse van 10 sc. par daechs... (fo 5 ).

12- Item Hendric Morael ende Joorijs den Dobbelaere hebben ghemetst an de vauteringhe van der nieuwer kerken beghinnende den $3^{n}$ in Julio... (fo $\left.5 \mathrm{v}^{\circ}\right)$.

13- Item Hendric Morael ende Joorijs de Dobbelaere hebben ghemetst in de nieukerke an den windelsteen commende van Gruuninghe in de selve nieukerke beghinnende den $29^{n}$ in October... (fo $\left.7 \mathrm{v}^{\circ}\right)$.

14- Item Hendrix Morael ende Joorijs voorn. hebben ghemetst an mijns heeren steeghere in de nieukerke ende ogiven ghesteken om den selven steeghere beghinnende den $3^{\text {en }}$ in December/elc 3 daghen... III lb. 3 sc. par. (fo 8).

Reparacien van Lootghietene.

15- Item de selve Willem (de Jaghere) heeft oversien ende ghesaudeert alle de goten van der hauder en de nieuwer kerken ende tusschen mijns heeren zale ende der nieuwer kerken ende oic den soldere boven der nieuwer kerken... $14 \mathrm{lb}$. par. (fo 12).

Reparacien anclevende den temmerlieden.

16- Item Arend (Charlet) ende Baltin (Valkeman) voors. hebben ghewrocht beghinnende den $13^{n}$ in December/ elc 2 daghen omme de fremeelen vander vauten in der nieukerke af te doene... $32 \mathrm{sc}$. par. (fo $\left.14 v^{\circ}\right)$.

Andere uutgheven extraordinaire

17- Item van 6 ronde hauten clossen die ande ijserin roede hanghen in de nieukerke... Item van 6 mindere in mijns galderije... ende drien cleenen clossen om in mijns heeren croone...

18- Item betaelt Matthijs van Roden van schildene de 3 mintste clossen an mijns heeren croone in zijn camere $24 \mathrm{sc}$. par. ( $\left.\mathrm{f}^{\circ} 15 \mathrm{v}^{\circ}\right)$.

Ibid., I reeks, rekeningen, nr 2067-2077. 
1481, 24 DECEMBER - 1482, 24 DECEMBER. - UITTREKSELS UIT DE REKENINGEN.

Rekeninghe Jans van Cuelne... ter cause van zekere ende diversche reparacien ende wercken ghedaen an den voors. clooster/an de huusen van der Vischmerct ende meer diverschen plecken.

1- Eerst pieter Scaelkin alias van Lede steenhauwer heeft ghelevert sichtent kerssavondt 81 zom de vreye van den windelsteen in de nieukerke metter bustweeren ende den lijsten boven ende beneden...

2- Eerst Hendric Morael ende Joorijs de Dobbelaere hebben ghesteken ogiven omme de windelsteen in de nieukerke. Uitgheven om temmerlieden

3- Item betaelt Roegire den scrijnmaker van den tween dueren te snijdene in mijnsheeren wijndelsteen... 18 sc. par. (f० 14).

4- Item Arend (Charlet) heeft noch ghewrocht in 't clochuus omme amelberghen/godewalen ende bertholf al nieuwe te verleestene beghinnende den $24^{\text {en }}$ in april elc 2 semi daghen comt 37 sc. par. (fo $\left.14 \mathrm{v}^{\circ}\right)$.

Ibid., I reeks, nr 2067-2077.

1493. - VERKLARING O.M. OVER DE DRINGENDE RESTAURATIE VAN DE KERK.

Zeker verclaers ende extract ter correxien summeerlijc ghemaect als van den lasten ende commere daer inne mijnen heere ende de kerke gehouden ende belast als nu noch ten daghe van heden zijn.

...Ende noch oic zo zulder moeten vele reparacien ghedaen werdden an de kerke ende huusinghe van den clooster grootelijicx van noode. Ende oic anders an de pachtgoedinghe bet dan $100 \mathrm{lb}$. gr.

Oic zo zal moeten de kerke onderhouden worden van lichte ende andere plusinghe... (f० 99; cfr. fo 168).

Ibid., Varia, I reeks, nr 619. 


\section{9. - REKENING UITTREKSEL I.V.M. HET BOUWEN VAN DE} NIEUWE TOREN.

Rekeninghe/verclaers ende bewijs van al dits her Andries van der Scaghen/religieus van diverschen personen in deughden ontfaen heeft... ter hulpen van den fabriken van den nieuwen torre omme dat de grote clocken daer inne zoude moghen ghehanghen werken der eeren Gods... ende ooc al 't ghuendt dits hij uutghegeven heeft ter causen van den voors. wercke alzo wel in ' $t$ afdoen van den ouden beelfroete als ooc in 't rechten boven ghedaen...

...Den temmerlieden (fo $3-4 \mathrm{v}^{\circ}$ )

1- Eerst Arendt Charlet ende Jan van der Gracht... ende Pietren Causin (de eerste twee werkten circa 22 weken, doch niet altijd aan de toren).

Uitgheven van IJserwercke... (fo $5 \mathrm{v}^{\circ}$ ).

2- Eerst den $19^{\text {n }}$ in September $99 .$. van 4 sommen scaelgenaghels

Item noch betaelt van 4 beckins die onder andt cruusen staen/ die boven up den torre ghestelt zijn... 24 sc. par.

Item van den zelven cruussen roet te schildeneren/andersins met olyververwen... 40 sc. par.

3- Item Pietren Lettejans/smet/ die ghelevert heeft de voors. cruusen ende weghten 100 ponden yser/ es betaelt $12 \mathrm{lb}$./ ende heeft noch ghelevert de lenen aldaer men gaet ten nieuwen torre waert ende wheegende $1714 \mathrm{lb}$. ende 1 half $\left(f^{\circ} 5 v^{\circ}\right)$.

4- Item Boudin Boene/steenhauwere van dat hij de gaten ghehouwen heeft daer de yserin lenen in staen up de voye... (fo 6 ).

5- Eerst betaelt Heyndric Morael ende Coppin zijn zone die ghemetst hebben omme de vuefstere daer men ' $t$ vier maken zal van den clocluders...

6- Item betaelt 2 ghesellen die d' oude te Lochmis ont-dect hebben... 48 sc. par.

7- Item Aelbrecht van Breeden van 10300 tichelen schoen te makene.

Ibid., I reeks, nrs 2067-2077.

1503, 24 DECEMBER - 1504, 24 DECEMBER. - UITTREKSELS UIT DE REKENINGEN.

Betalinghe ghedaen diversche werclieden van der kerken.

Eerst metsers beghinnende de $1^{\mathrm{e}}$ weeke den 14 in Lauwe 1503 (o.s.) 
1- Item betaelt vier ghesellen die d'orduun hebben helpen lossen uuten scepe te wetene de twee boghen an de costerie in de Noortzijde... (fo 1 ).

2- Item betaelt van 1400 stopnaghelen verbesicht bij den metssers om de nieu vaute... 12 sc. par. (fo $4 \mathrm{v}^{\circ}$ ).

3- Item betaelt van 12 stroen matten die ghehanghen zijn voor de ghelaesvenstere in de Noortzijde... 8 sc. par.

4- Item betaelt van 12900 correelen te doen cruene van up 't water tot in't kerkof.../ item betaelt van 12700 coreelen.../ item betaelt van 25000 coreelen te doen crudene... (fo $\left.5 v^{e}\right)$.

5- Item Hayne de ghelaesmakere heeft ghestelt twee glaesvensteren in 't saelkin in de costerie... $12 \mathrm{sc}$. par. (f० 10).

6- Smet Pieter Letteljans/ item den yseren balcke ligghende in de noortzijde boven de costerie weecht $846 \mathrm{lb}$. ... Item de coppelroe duer de costerie wecht $107 \mathrm{lb}$. (fo 11).

Ibid., I reeks, nr 2067-2077.

1567, 2 OCTOBER. - VERSLAG DOOR DE RAAD VAN VLAANDEREN I.V.M. DE VERWOESTINGEN DOOR DE BEELDENSTORMERS IN 1566 AANGERICHT IN DE SINT-PIETERSABDIJ.

Comme il a pleu à son altesse/pour l'absence de Mgr le président de Flandres/ordonner que par moy Franchoy de Courtewille/conseiller ordinaire au dict Flandres avecq $\mathrm{m}^{\text {re }}$ Jean van der Burght aussi conseiller audict Flandres/ fust par achevé l'informacion en commenchée par les dicts seigneurs président et van der burg sur le faict des troubles de l'an $\mathrm{XV}^{\mathrm{c}}$ LXVI/ Et que par eulx n'avoit parfurny ne qu'estoit ordonné de faire et besoigner en ceste ville de Gandt après avoir receu le besoigne du dict seigneur président et visité le contenu d'iccelluy/sommes allé avant à la visitacion tant des monastères, hospitaulx que esglises paroichiales/collecgiales que aultres de lad. ville de Gand à la manière que s'ensuit ( $\mathrm{f}^{\circ} 314$ ).

(le $2^{\mathrm{e}}$ jour d'octobre 1567). De la sommes allez à l'abbaye de St-Pierre à Gand où que ayant parlé à Mgr le prélat nous faist mener par aulcuns religieulx en l'eglise et premiers en la nef monstrant illecq trois aultelz et le crucifix avoir esté rompuz ensemble aussy l'autel St andrieu avecq la sépulture faict faire par le prelat moderne et ung aultre autel du costé des galleries du couvent/ De là allont du dict aultel de St-Andrieu plus avant vers le repositoire du st sacrament nous fust montré en la chapelle de sainct Denys que les fenestres et verrières avoient esté persées et brisées ensembly aussy l'autel/ reservé que la table ducict aultel avoit esté ostée et préservée/ Aussy nous fust monstré du meisme costé une aultre chapelle qu'on dict estre la chapelle du prevost/et dirent qu'icelle avoit par les sectaires esté rompue/signament les tableaux/verrières et gastées/ avecq l'oratoire du prelat qui avoit este faict faire en la meisme chappelle/et 
passant oultre/en la chappelle de nostre dame derière le grand choeur/ nous fust monstré que l'autel/verrières/sièges et toutes aultres décorations avoient esté gastées/rompues et brisées/ Allans de là en les chappelles de Ste Amelberghe et St Laurens les aultels desquelles avoient aussy esté rompues et les verrieres persées/ Et de là sommes entré le grand choeur vers le grand aultel lequel a ausay esté rompu et brisé reservé le rondeau ou arcq dudit aultel qu'est demeuré sans estre rompu/ Comme avons veu rompu et brise audict choeur le repositoire du St-Sacrament fort sumptueulx/ tout taillé de pierre de marbre et de toux/ les sièges des officaulx fais d'allabastre/aussy tous rompus et brisez/Comme ont esté aussy en plusieurs endroicts gastes leurs sièges du grand choeur où les religieulx chantent le service divin/aussy la sépulture de l'abbé trepassé et ung aultel et St-Sepulture derrière ledict grand aultel/ qu'estoit aussy d'allebastre. Aussy disoyent lesd. religieulx que tous les livres/tant servant à chanter que de la librairie estoyent gastés/ De la allant par ung degré en hault du costé du St-Sacrament nous fust monstré l'aultel de St-Guerardt et les verrières y avoir esté rompues/Nous fust aussy monstré allant ung peu plus avant ung aultre aultel de la Ste Trinité dessus la dicte chappelle de nostre dame derrière le grand choeur lequel et les verrières avoient toutes esté rompues et brisées comme aussy de la Ste Trinité rompues et gastées/ Aussy nous fusmes monstré le brisement et rompture de la librairie et sur le dormitoire/sans qu'ilz scavoyent estimer le dommage inferé et souffert par led. brisement/Combien que avons veu et trouvé que le tout estoit pour le present fort bien et honnestement reparé (fo 321-322; cfr. fo $336-337$ ).

Algemeen Rijksarchief Brussel, Raad van Beroerte, nr 55; cfr. Ibid., nr 254.

\section{7. - UITTREKSELS UIT DE REKENINGEN.}

Receul et descharge/compte et reliqua de la generale recepte... faicte pour Henry de Costenobel/secrétaire.

1- Item le 24e d'Avril 1567 paiet à Jacques Gerolf/voirier/à bon compte des ouvrages aultour du coeur de l'église la somme de $7 \mathrm{lb}$. gr.

2- Item paiet à Jacques Gerolf/voirier à bon compte sur ce qui luy est deubt des reparations de l'église par quitance datée du $29^{\circ}$ de Jullet $1567 \ldots 13 \mathrm{lb} .14$ sc. $8 \mathrm{~d}$. gr.

3- Item payet à Jacob Gheerolf/ vorier de Monseigneur/par quictance du $29^{\circ}$ d'Octobre... à bon compte des voires de la dicte eglise... $14 \mathrm{lb}$. gr.

4- Le 24 Decembre 1567, payet à Mr Jan Mijnsheeren par quictance cy rendue la somme de $16 \mathrm{lb} .13 \mathrm{sc} .4 \mathrm{~d}$. gr.

Rijksarcbief Gent, Fonds van de Sint-Pietersabdij, I reeks, nr 1963. 
1573. - REKENING I.V.M. DE RESTAURATIE VAN DE KAPEL VAN DE H. MARIA-MAGDALENA.

Exposita pro reparatione sacelli Beatae Mariae Magdalenae.

1. Primo Philippo Damman carpentatori... 4 lb. 8 sc. gr.

Item cuidam pictori

Item cuidam sculptori de sex angelis reformandis

Summa omnium expositorum pro reparatione sacelli B. Mariae

Magdalenae... $4 \mathrm{lb}$. $6 \mathrm{sc}$. gr.

2- Exposita pro repartione sedilium mulierum sinistri chori una cum sacello B. Barbarae et novo altari (in eodem sacello wordt elders gezegd).

Primo Philippo Damman carpentatori...

$12 \mathrm{lb}$. gr.

Item latomo de sex diebus

9 sc. gr.

Item famula ejus de totidem diebus

5 sc. gr.

Item cuidam pictori

5 sc. 8 gr.

Item adhuc pictori

13 sc. gr.

Item cuidam voor een vijftich paveersteenen

in ecclesia

11 sc. 8 gr.

3- Item magistro Henrico Ballare pro reparatione imaginis

Beatae Barbarae

4 sc. 6 gr.

Ibid., I reeks, Varia, nr 124, fo $9 \mathrm{v}^{\circ}$

1575 (n.s.), 16 JANUARI. - UITTREKSELS UIT DE REKENINGEN I.V.M. DE RESTAURATIE VAN DE KERK.

1- Pro imaginibus et pr screnis dandis

2 sc. 8 gr. (fo $41 v^{0}$ ).

2- 23 Januari... Christoforo Goethals pro clausura parvae fentrae super summun (?) altare in taswerck $30 \mathrm{sc}$. gr.

Eidem pro dispositione vitri 5 s.g. Eidem de uno die quo laboravit in clausura sepulcrorum in ecclesia cum famulo $2 \mathrm{~s}$. 4 d.g. (fo $41 \mathrm{v}^{\circ}$ ).

3- 23 November. - Viduae Jacobi Gheerolf vitrificis de diversis reparationobis pro conventu... 3 lb. 11 s. 10 d. gr. (fo $62 \mathrm{v}^{\circ}$ ).

Ibid., I reeks, Varia, nr 124. 
1576, 8 JULI. - UITTREKSEL VAN DE REKENINGEN I.V.M. DE RESTAURATIE VAN DE KERK.

Pro reparatione graduum domus angularis ecclesiae nostrae 6 s. 8 d. gr. Ibid., I reeks, Varia, nr 124.

1585, 20 JANUARI. - REKENING IN VERBAND MET HERSTELLINGEN VAN DE ABDIJGEBOUWEN EN DE KERK.

1- ...Livinae scelvergher pro labore suo in sacristia Abraham Pieters vitrifici... 35 s.g.... adhuc in opere chori Johanni van de Walle de 8 diebus quibus laboravit lathomo...

...Erasmo de Sceppere... de 10 diebus... Petro Veerman... de 8 diebus (daarenboven een aantal gezellen).

2- 17 februari... Andreae van Hove, lathomo de 5 diebus... Mathiae van Hove filio de 10 diebus... Jonae Stalins famulo de 13 diebus... Joanni van de Walle famulo de 7 diebus... Livino Legiers lapicidae de 5 diebus quibus laboravit in choro... et Johanni Steendam de 5 diebus...

3- 12 mei... Philippo de Vos plumbifusori pro reparatione tecti in cimiterio supra puteum... ab Alberto Martins vitrifici voor een nieu gelaesveistere in den Hoeghen cooer grooct 28 voeten simul $2 \mathrm{lb}$, 2 s.gr. Noch een nieu veistere gemaect in de groote forme grooet 6 voeten... compt. p.s. gr. noch een gelas verlooet in deselve forme grooet 4 voeten nieu compt. 3 s.g. noch aldaer gestopt 54 rutem... g.s. Noch gedaen op den grooten en de cleenen pant ende ijserem roen met de naghelen om de cassinen te naghelenne.

6- 16 juni. Livino Carèse de ter mille lapidibus et ampluis correel... Johanni Rooman fabri pro ferrea cruce super turrim ecclesiae $33 \mathrm{s.} 4 \mathrm{~d}$. Eidem voor eenen clocclepele voor de cleene clock $41 \mathrm{lb}$. weghende 3 s. 8 d.g.

5- 1 september... Georgio van den Steene carpentatori cum suo filio de sex diebus quibus laboravit ad portam et in conventu et super turrim... 24 s.g. Johanni van de Walle, lathomo, de 15 diebus quibus laboravit in claudendo hostia et fenestris versus cimiterium s. Michaelis et pro conventu(?) et in sacristia et ecclesia... $2 \mathrm{lb}$. g. famulo ejus de totidem... 25 s.g.

6. 26 Ootober... Georgio van den Steene cum filio carpentario de 10 diebus quibus laboravit in conventu et in locis privatis in dormitorio et circa infirmariam... Johanni van de Walle lathomo de 5 diebus quibus laboravit in ecclesia et in conventu... Arnoldo d'Inghelsche famulo ejus de titidem. 
7- 3 november... Pro duabus cortinis et duabus imagini bus pro sacello Ste Vincenti 5 s. 8 d. g.

8- (Inkomsten)... a Petronilla Verhoeven pro reparatione sacelli Sancti Vincentii par F. Franciscum Ruuselaert 4 s. 10 d.g. ab Elizabeth Vasta per cundem ab candem

9- 29 december... Cornelio Wauters de 550 lapidibus paveertigghelen

Rijksarchief Gent, Fonds van de Sint-Pietersabdij, I reeks, Varia, nr 124.

1585, 15 APRIL. - OKTROOI VOOR HET LICHTEN VAN FL. 32.000 TER HERSTELLING VAN DE ABDIJ.

Philippe, par la grace de Dieu, Roy de Castille,... Conte de Hasbourg, de Flandres,... A tous ceulx qui ces presentes verront, salut. Sçavoir faisons: nous avoir receu l'humble supplication et requeste des Abbe, religieulx et couvent du monastere de Sainct Pierre au mont Blandin, lez notre ville de Gand, de l'ordre de Sainct Benoist. Contenant que doiz le commenchement des derniers troubles ils ont este par les hereticques et noz irebelles expulsez hors de leur cloistre, et apres long et peneux exile, desirans y retourner pour servir Dieu et vivre regulierement selon leur ordre et profession ny trouvent que desolation et irreparable ruyne, estant l'eglise, dortoir, et la pluspart des ediffices jusques aux fondemens rasez et demoliez par les dictes rebelles, lesquelez oultrele sacrilege et pillerie de tous les joyaulx, ornemens d'eglise, bibliothecque et meubles, ont durant les dictes troubles, occupez et receuz les revenuz et biens du dict cloistre et xeulx tant dommageablement desnuez saccagez et destraictz que n'est demeure bois, arbre ny aulcune aultre apparante despouille,... Estant neantmoings pardessus tout ce que dict est, tres necessaire de trouver deniers pour restaurer l'eglise quelque peu raccommoder le dicte cloistre tant miserablement ruyne... Quoy considere et affin que le dicte monastere fondez par noz prodecesseurs Contes de Flandres... Xeulse remonstrans nous ont tres humblement supplie que pour... restauration bien et urgente necessité du dict cloistre en attendans une saison plus benigne et fructueuse qu'il nous pleust leur accorder noz lettres patentes d'octroy pour pouvoir lever en deniers capitaulx pour une fois a charge d'en rendre bon et loyal compte et renseing la et ainsy que appertiendra la somme de trente deux mille florins de vingt pattars piece a cours de rente le rachapt au seize ou aultre denier licite avecq auctorisation de pouvoir ad affecter et obliger telles partyes des biens temporelz de leur dicte cloistre que, pour la deue asseurance et contentement des crediteurs conviendra...

...Inclinans favorablement a la supplication des dictes supplians. Leur avons octroyé consenti et accorde, octroyons consentions et accordons, en leur donnant congié et licence de grace especialle par ces presentes qu'ilz puissent et pourront lever et charger les biens de leur dicte maison jusques a la somme de trente deux mil livres de quarante groz de notre monnoye 
de Flandres la livre par vendition de rente au cours et rachapt du denier seize ou aultre pris approuvé et licite, et xelles pouvoir asseurer et hypotecquer sur les biens temporelz de leur dicte maison et monastere au moindre fraiz que faire se pourra, pour les dictes deniers estre employez a la reedifications et reflections de leurs eglise, cloistre, censes, maisons et dicaiges... et non a aultre usaige, pourveu que les dictes supplians obtiennent cy apres ladveu ou consentement de notre St. Pere le Pape ou de leurs superieurs... sans leur faire mectre ou donner ne souffrir estre faict mis en notre ville et cite de Tournay le quinziesme jour du mois d'apvril, l'an de grace mil cincq cens Octantecincq. De noz regnes asscavoir des Espaignes Sicille etc... le 30 et de Naples le $32^{\text {1eme }}$.

\author{
Par le Roy \\ en son conseil \\ Le Comte
}

Archief van de St.-Baafskathedraal te Gent, Fonds der St.-Pietersabdij, XIX 38.

\title{
1585, 30 OCTOBER. - LENING VOOR HET HERSTELLEN VAN DE ST.-PIETERSABDIJ.
}

Den voorlesten van October 1585, alzo mijnen eerw. heere ende de ghemeene religieusen ende convent als. doen mits den brake ende ruyne van heuren clooster ende huysinghe van dien noch te Doornick hemlieden waren houdende in 't clooster van den Cruysbroeders ende dat zij omme de betalinghe van den groote reparation aen heurlieden voorn. gheruineerde clooster alreeds ghedaen als van den gueune noch staende nootzakelijk totter dienste God's ende ten fine zij volghende heuren profectie zonder moghen wederkeeren ende daerinne gheaccommodeert worden te doene zeere benodicht ware van ghelde oick dat zij midts dien ende omme 't zelve te moghen becommen, vercreghen ende zijne Majesteit hemlieden verleendt hadde zekere opene letteren van octroye ende consente van belastinghe totter somme van (open) eens in daten 15 April 1585 so eyst dat dies volghende mijnen voors. eerw. heere ende de voors. ghemeene religieuse... by heuren lettren van procuratie speciale in dato 28 October $1585 \ldots$ last ghegheven... den convents behoeff te lichtene,... eene somme van 6000 guldens...

$$
\text { R.A.G., I reeks, nr 2306, fo 122-124. }
$$




\section{5(?). - ABT HUBEERT KLAAGT BIJ PAUS SIXTUS V OVER DE VERNIELING VAN SINT-PIETERSABDIJ.}

Lambertus Huberti doet syne clachten aen Sixtus V; de vijanden het clooster verdestrueert hebbende.

...in de vasa, vestes, atque alias res sacras, et reliquam omnem suppel. lectilem, post devastata praedia, et stabilia bona, euisdem monasterii occupata...

...Omnia fere fissalia et breviaria, reliquos que libros, qui decantandis et recitandis, divinis officiis carumque ceremoniis, et ritibus antiquis, inserviebant, dilacerassent, combussissent abtulissent, et alias perdidissent, ita ut ex his qui postea, reperti, et recuperati sunt, unum atque alterum exemplar tantum manuscriptum (prout in dicto monasterio, non aliorom quam manuscriptorium Librorum usus erat) de presenti supersiut...

\section{Archief van de St.-Baafskathedraal te Gent,}

Fonds der St.-Pieters-abdij, XIX 40.

1613, 25 JUNI - 1614, 24 JUNI. - REKENING VAN JOOS DE BRUNE.

1- Betaelt Gheeraerdt Spillebaut metser... ter causen van metserije bij hem ghedaen an Sente Vicentius cappelle danof volghende de metinghe ghedaen bij $\mathrm{mr}$ Lieven van Thuynen ghesworen landtmeter dezer stede bevonden es inden meur metten bezette ende het paveersel ende met een ander muerken jeghens den lochtinck... de somme van $26 \mathrm{lb} .16$ sc. 4 gr. (fo. 106).

2. Jan de Croock calcman... ter causen van zeven en dertich mudden en half calck bij hem ghelevert ten behoefve van de voorseide Sente Stevins cappelle t'sedert den $5^{\mathrm{n}}$ September 1615 tot $4^{\mathrm{n}}$ October daernaer... 11 lb. 6 sc. gr. (fo 106).

3- ...Jan Impens schailgedecker... ter causen van het schailgedack bij hem ghevrocht up de jeghenwoordighe kercke int clooster... $27 \mathrm{lb}$. 18 sch. 11 gr. (f० 113).

R.A.G., Fonds van de St.-Pietersabdij, I reeks, nr 2309. 
1614, 8 FEBRUARI. - MAKEN VAN SLEUTELS.

1- Dut es ghemaeckt om de kercke vanh et clooster van Ste Pieters neffens Gent bij laste van mijnheer Rym den $8^{\mathrm{n}}$ februarye 1614, heeft eenen sluetel om den coefere inde cakerystye... $10 \mathrm{gr}$.

2- Noch twee vyercante crammen ghehalt bij den temmerman... 12 gr.

3- Noch eenen sleutel om de soenghers van de keercke... $10 \mathrm{gr}$.

Somma bedraecht 2 sc. 8 gr.

Ibid., II reeks, nr 377

1614, 2 SEPTEMBER. - REKENING VOOR HET HANGEN EN AFNEMEN VAN TAPIJTEN IN DE ABDIJKERK.

Ick onderschreven kenne ontfaen te hebben uuter handt van joncheer Jake als ontfangher van der pitancie de somme van $10 \mathrm{sc}$. gr. ende dat van het hanghen ende afdoen van de tapijtsen van der kercke van St-Pieters clooster. Welcke somme verschenen is St. Pietersdaghe den $3^{\circ}$ Junii 1614. Mij 't oorconden desen 11 September 1614

Colmuumbanus Comyn, sacrista

Ibid., II reeks, nr 406

1623. - IN DE O.L. VROUWKAPEL WORDEN DRIE VENSTERS VERVANGEN.

De abt heeft eerst in $1623 \ldots$ doen weeren ende uutdoen drij ghelasveynsters in Onze Lieve Vrauwe cappelle achter den hooghen aultaer staende ter Oost zijde, Noortzijde ende zuudtzijde daerinne waeren eenighe onbekende figueren, ende in de plaetze van diere doen stellen drije andere, ter oostzijde de crooninghe van O.L.Vrauwe, ter noortzijde het cruucen van Ste Pieter ende ter zuudzijde de onthalzinghe van Ste Pauwelse...

Archief van de O.L. Vrouw parocbiekerk van St-Pieters te Gent, IV B.a.10. 


\section{$-60-$}

\section{4, 1 JULI - 1625, 1 JULI. - REKENING VAN DE} OPPERKOSTERIJ.

Item bethaelt aen Pieter Franc voor 't scoonmaken van de coperen beelden van Onse L.Vrauwe autaer. 3 sc. gr. (fo 7 ).

R.A.G., Fonds van de St.-Pietersabdij, I reeks, nr 1929.

$$
-61-
$$

1672, 22 AUGUSTUS. - UITTREKSEL UIT HET PROCES VAN DE KERKMEESTERS VAN DE O.L. VROUW PAROCHIEKERK TEGEN DE ABT VAN ST.-PIETERS.

Pastor ende kerckmeesters van O.L.Vrauwe contra den Heer Prelat van S. Pieters over d'ysere Baillie aen 't kerckhoff, door sijnen Bailliu ende officieren afgesmeten ${ }^{1}$.

\section{Copie}

Advertissement omme prior, religeusen, ende convent van Ste Pieters neffens Ghendt, verweerders ter eendere, jeghens pastor, ende kerckmeesters van Onse Lieve Vrauwe heeschers bij requeste, ende versouckers van provisie ter andere voor mijn Edel heere den Raedsheere Claissone commissaris inde saecke.

6. Ende om te betooghen, dat daude kercke heeft ghestaen op de selve plaetse daer de nieuwe ghestelt is/ende dat die den selven wt, ende inganck heeft ghehadt, soo wordt alhier overgheleyt een aude caerte figuratieve, gemaeckt voor het beginsel vande nieuwe kercke cotte $d^{2}$.

$$
\text { Ibid., II reeks, nr } 679 .
$$

(1) De pastoor en de kerkmeester verloren het proces.

(2) Dit plan ontbreekt in het dossier. 